\title{
$\mathrm{UiO}$ : Det juridiske fakultet
}

\section{Fredsplikt og politiske aksjoner}

Kandidatnummer: 216

Leveringsfrist: 15. januar 2013

Antall ord: 28955

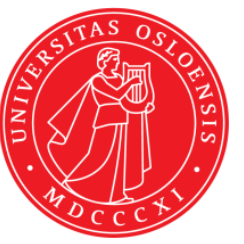




\section{Innholdsfortegnelse}

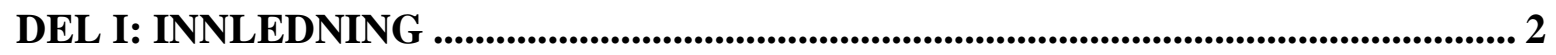

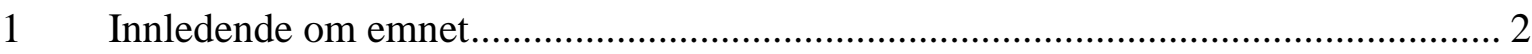

2 Fredsplikt, arbeidskampbegrep og terminologi ..................................................... 3

3 Rettskildegrunnlag, tilnærminger og videre fremstilling ………………………...... 7

DEL II: FREDSPLIKTENS SAKLIGE SIDE ..................................................................... 10

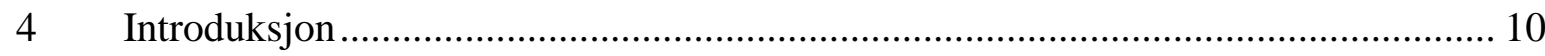

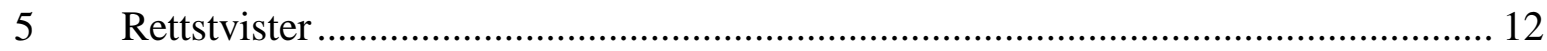

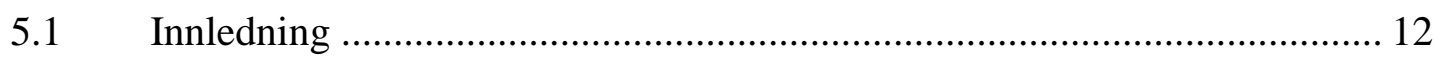

$5.2 \quad$ Nærmere om rettstvister ...................................................................... 13

$6 \quad$ Beslutninger som faller innenfor arbeidsgivers styringsrett................................... 16

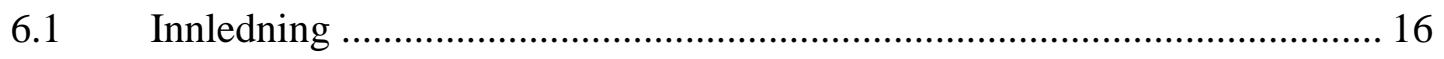

6.2 Beslutninger som etter sin art er utøvelse av styringsrett ........................... 17

6.3 Hvem kan utøve styringsrett .................................................................. 22

6.31 De aksjonerendes arbeidsgiver .............................................. 22

6.32 Særlig om politiske organers/ personers deltakelse ved

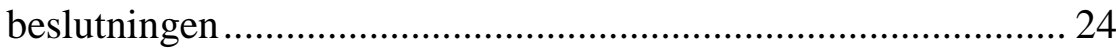

6.33 Identifikasjon ................................................................... 27

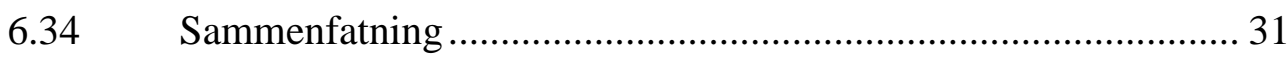

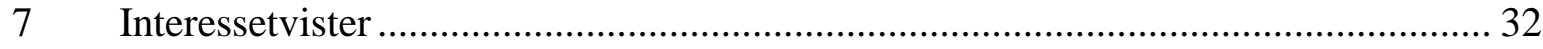

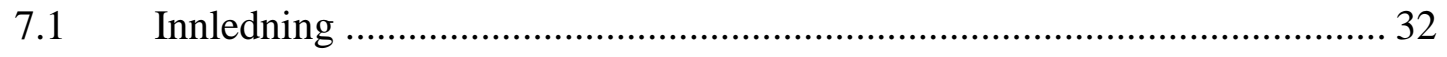

7.2 Forholdet til aktuell regulering .............................................................. 34

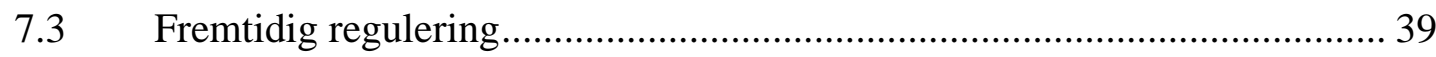

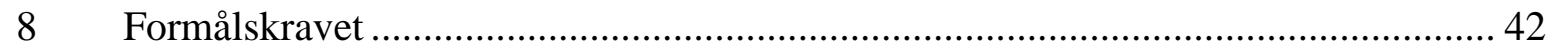

$8.1 \quad$ Innledning ................................................................................... 42

8.2 Momenter som kan belyse det reelle formålet .............................................. 43

8.3 Aksjonen har en type formål ..................................................................... 49 
8.4 Aksjonen har et sammensatt formål ................................................... 51

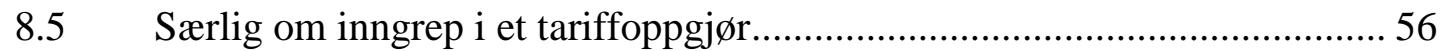

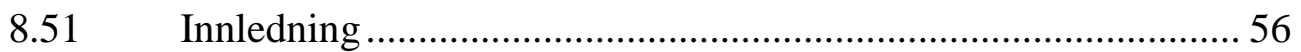

$8.52 \quad$ Situasjonen ved tvungen lønnsnemnd .................................. 57

$8.53 \quad$ Andre inngrep i et tariffoppgjør............................................. 60

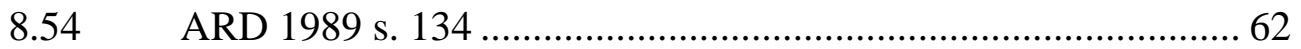

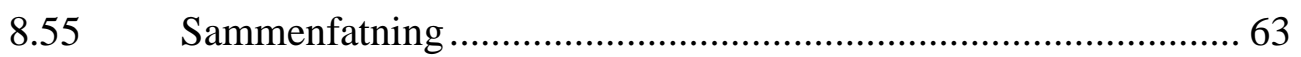

DEL III: ANDRE FORHOLD SOM KAN HA BETYDNING FOR EN POLITISK AKSJONS RETTMESSIGHET ......................................................................... 65

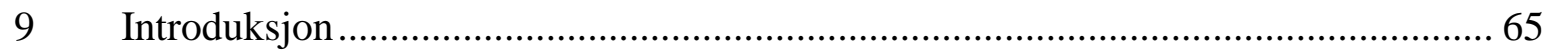

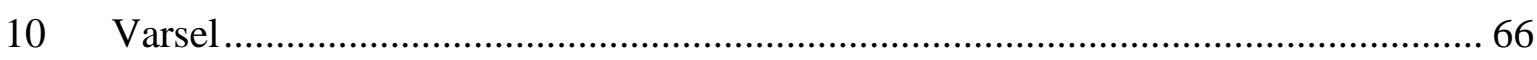

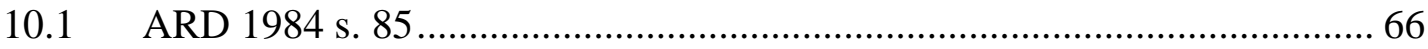

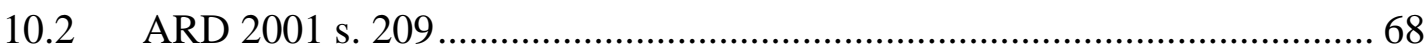

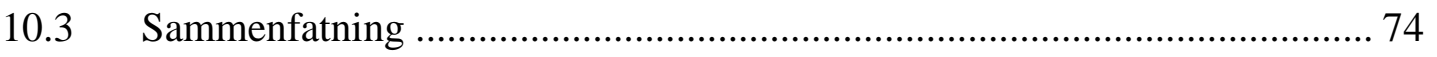

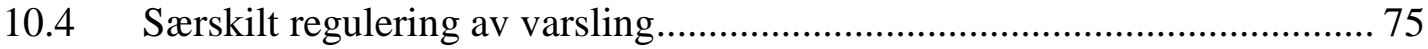

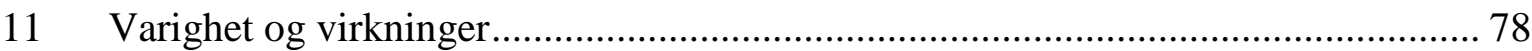

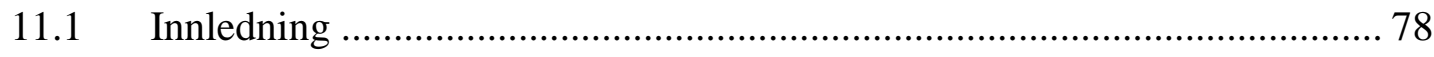

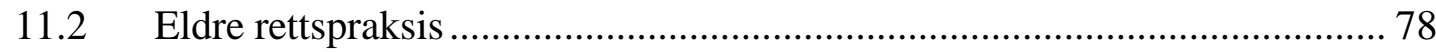

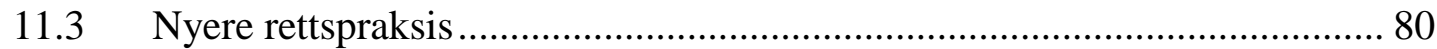

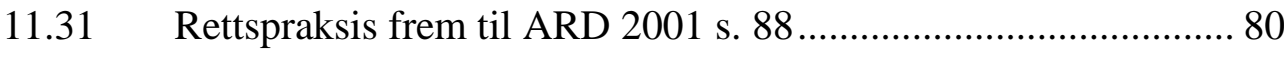

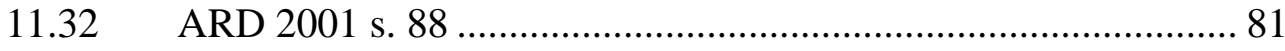

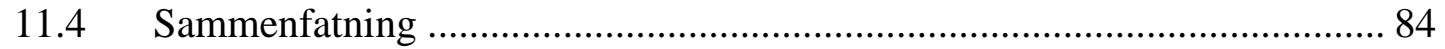

DEL IV: AVSLUTTENDE BEMERKNINGER ........................................................... 87

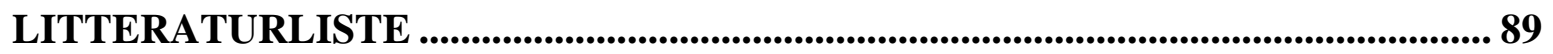




\section{Del I: Innledning}

\section{Innledende om emnet}

Fredsplikt er et grunnleggende element i tariffretten, og innebærer kort sagt en plikt til å avstå fra og til å motvirke bruk av arbeidskamp i rettstvister og, med noen modifikasjoner, i interessetvister. Fredsplikten hviler på et dobbelt rettsgrunnlag: tariffavtale og lov. De ulike rettsgrunnlagene er uttrykk for at fredsplikten skal ivareta ulike hensyn. Den avtalebaserte fredsplikt er utslag av partenes interesse $\mathrm{i}$ arbeidsfred, herunder av |hensynet til stabilitet og forutsigbarhet i tariffavtaleforholdet. Mens arbeidstvistlovens ${ }^{1}$ og tjenestetvistlovens ${ }^{2}$ bestemmelser om fredsplikt er utslag av den samfunnsmessige interessen i arbeidsfred.

Fredsplikten gjelder i hovedsak for tvister mellom partene og er ikke til hinder for demonstrasjon av enhver oppfatning. Den utelukker ikke gjennomføringen av «politiske aksjoner». Andre betegnelser på det samme er «demonstrasjonsaksjoner»og «politisk streik». At demonstrasjonsaksjoner faller utenfor fredspliktens område, har lang tradisjon i den kollektive arbeidsrett i Norge. Allerede i ARD 1920-21 s. 1 slo Arbeidsretten fast at fredsplikten ikke var til hinder for en «politisk arbeidsnedleggelse, rettet mot statsmyndighetene, ikke mot arbeidsgiverne» (s. 5). Innholdet av denne reglen har blitt presisert og utviklet $\mathrm{i}$ en rekke dommer siden. Formålet med denne avhandlingen er å undersøke hvilken adgang en tariffpart har til å gjennomføre slike aksjoner uten at dette kommer i konflikt med fredsplikten. De to sentrale spørsmålene blir hvordan man skal trekke grensen mot opptreden som er å anse som arbeidskamp, og om det kan oppstilles ytterligere rettmessighetsvilkår knyttet til gjennomføringen av aksjonen. Problemstillingene vil først og fremst drøftes ut fra nyere rettspraksis, fra 1989-90 og frem til i dag.

Lov 27. januar $2012 \mathrm{nr} .2$ om arbeidstvister (arbeidstvistloven) (arbtvl).

2 Lov 18. juli $1958 \mathrm{nr} .2$ om offentlige tjenestetvister (tjenestetvistloven) (tjtvl). 
Bakgrunnen for dette tidsmessige skillet er Nerdrums behandling av emnet i $1989 .{ }^{3}$ Nyere rettspraksis vil imidlertid også bli sett i sammenheng med eldre rettspraksis, dels fordi eldre praksis er viktig ved fastleggelsen av gjeldende rett, og dels med sikte på å undersøke om det har skjedd en endring eller utvikling i forhold til eldre rettspraksis.

\section{Fredsplikt, arbeidskampbegrep og terminologi}

De alminnelige reglene om fredsplikt etter lov og tariffavtale er $\mathrm{i}$ all hovedsak sammenfallende. ${ }^{4}$ I prinsippet er det imidlertid ingenting i veien for at det følger en videre fredsplikt av tariffavtalen enn av loven. Partene kan derimot ikke avtale en mindre omfattende fredsplikt enn det som følger av arbeidstvistloven og tjenestetvistloven. Dette følger allerede av at den lovbestemte fredsplikt har grunnlag i andre hensyn enn til partene. Det ville derfor være unaturlig om partene kunne avtale en snevrere fredsplikt enn det som følger av loven.

Ett eksempel på at det kan følge en videre fredsplikt av tariffavtaler enn av arbeidstvistlovene, er regulering av sympatiaksjoner. Et mer spesielt tilfelle finnes i ARD 1994 s. 246. I saken var en interessetvist mellom partene brakt inn for behandling hos Rikslønnsnemnda etter tjtvl § 26a. Tariffavtalen besto med virkning for den tariffmessige fredsplikt, men ikke med virkning for den lovbestemte fredsplikt etter tjtvl $\S 20 \mathrm{nr}$. 2. Disse forskjellene mellom de to rettsgrunnlagene har imidlertid ikke betydning for problemstillingen i denne avhandlingen.

Det er også full adgang til å avtalefeste ytterligere rettmessighetsvilkår for politiske aksjoner enn det den lovbestemte fredsplikt gir grunnlag for, for eksempel om krav til forhåndsvarsling. Hovedavtalene LO - NHO og HSH - LO er eksempler på at dette er

\footnotetext{
$3 \quad$ Nerdrum 1989.

$4 \quad$ Ot.prp. nr. 33 (1965-66) s. 3.
} 
gjort. ${ }^{5}$ Jeg har ikke foretatt noen fullstendig unders $\varnothing$ kelse av i hvilken utstrekning slike reguleringer finnes, men kommer tilbake til enkelte bestemmelser senere, der de systematisk sett hører hjemme.

Som det fremgår av kapittel 1 innebærer fredsplikten en plikt til å avstå fra og til å motvirke bruk av arbeidskamp. Fredsplikten, herunder arbeidskampbegrepet, har to sider; en subjektiv og en objektiv. ${ }^{6}$ Den objektive siden omhandler spørsmålet om hvilke typer aktivitet som kan falle innenfor fredspliktens ramme. Begrepet «arbeidskamp» er overordnet og omfatter mange ulike former for kampskritt. To av disse fremgår uttrykkelig av arbeidstvistlovene: streik og lock-out, se arbtvl $\S 8$ jf $\S 1$ bokstav f og g og tjtvl $\S 20$. Streik er det primære kampmiddelet for arbeidstakere, og kjennetegnes ved at en eller flere av arbeidstakerne nedlegger arbeidet i sin helhet. Lock-out er derimot betegnelsen på et av arbeidsgivers kampmidler, og innebærer at arbeidsgiver hindrer de ansatte i å utføre sitt arbeid. Arbeidskampbegrepet omfatter imidlertid også andre former for kampskritt, som i disse lovbestemmelsene betegnes som «annen arbeidskamp». Lovene gir liten veiledning for hva slags opptreden dette kan være. Arbeidsrettens praksis har imidlertid lagt en vid fortolkning av begrepet til grunn, og det er vanskelig å se for seg opptreden som objektivt sett ikke kan kvalifisere til å være arbeidskamp. Begrepet omfatter eksempelvis delvis arbeidsnedleggelse, herunder overtidsnektelse og gå sakte-aksjoner, men også rene unnlatelser og trusler om kampskritt. Et annet viktig poeng er at arbeidskampbegrepet ikke er begrenset til å gjelde opptreden som vil innebære mislighold av de individuelle arbeidsavtalene. ${ }^{7}$ Det er imidlertid ikke nødvendig å gå nærmere inn på arbeidskampbegrepets objektive side her. ${ }^{8}$ Det har ingen betydning for det som er temaet $\mathrm{i}$ denne avhandlingen.

5 Hovedavtalen 2010-2013 LO - NHO § 3-14, Hovedavtale 2010-2013 HSH - LO § 6-3.

6 Evju 1982a.

7 Jf eksempelvis ARD 1985 s. 96 hvor det fremgår at «[d]et er således ikke tvilsomt at fredsplikten er til hinder også for kampmidler som ikke innebærer nedleggelse eller tilsidesettelse av direkte arbeidsplikter» (s. 108).

8 Om begrepet «annen arbeidskamp» se Thorkildsen 1990. 
Det som derimot er av helt sentral betydning, er fredspliktens subjektive side. Dette er spørsmålet om betydningen av aksjonens formål. I motsetning til det som gjelder ved den objektive side, ligger det her en rekke begrensninger i fredsplikten. Som tidligere nevnt innebærer fredsplikten et forbud mot arbeidskamp i rettstvister og, med noen modifikasjoner, i interessetvister. Dette følger direkte av arbtvl $\S 8$ første og annet ledd og av tjtvl $§ 20$ nr. 1 og nr. 2 første ledd. En rettstvist er en tvist om en tariffavtales «gyldighet, forståelse eller eksistens eller om krav som bygger på en tariffavtale». ${ }^{9}$ En interessetvist er en uenighet om «ordningen av fremtidige arbeids- og lønnsvilkår». ${ }^{10} \mathrm{I}$ rettstvister er fredsplikten absolutt. Dette er begrunnet med at rettslige tvister skal løses ved rettslige prosedyrer. I ARD 1923 s. 78 kom dette til uttrykk som at «[d]et rettsstridige må ligge i selve dette at man ikke gå rettsveien, men vil tvinge sig frem og vil søke å sette sin motpart i en sådan tvangssituasjon at ham må bøie sig for overmakten» (s. 84). I interessetvister er derimot fredsplikten relativ, både i sak og i tid. Dette kommer jeg tilbake til. Allerede her er det imidlertid på sin plass å nevne at fredsplikten i første rekke knytter seg til det som er tariffregulert i tariffperioden. Her kan det vises til ARD 1920-21 s. 1, hvor det ble bemerket at «tariffoverenskomstene er vistnok, som ved gjentagne dommer fastslått, basert på forutsetningen om at der i tariffperioden skal herske arbeidsfred mellem partene ..., og at ingen av partene derfor kan være berettiget til i tariffperioden å anvende kampmidler for å fremtvinge endringer i de ved overenskomsten ordnede arbeidsforhold» (s. 5).

Når det gjelder interessetvister, er det kun kampskritt som knytter seg til inngåelse eller revisjon av egen tariffavtale som omfattes av arbeidskampforbudet. Dette fremgår ikke uttrykkelig av arbeidstvistlovene, men er sikker rett. ${ }^{11}$ Av denne grunn faller sympatiaksjoner i utgangspunktet utenfor fredspliktens ramme. Det grunnleggende vilkåret for at sympatiaksjoner går klar av fredsplikten, er at hovedkonflikten er lovlig. Ettersom fredsplikten i rettstvister er absolutt, vil sympatiaksjoner til støtte for en rettstvist være utelukket.

\footnotetext{
9 Jf arbtvl $\S 1$ bokstav i og tilsvarende bestemmelse i tjtvl $\S 20$ nr. 1.

10 Jf arbtvl $\S 1$ bokstav j og tilsvarende bestemmelse i tjtvl $\S 20$ nr. 2 første ledd.

11 Evju 1982b s. 107, med videre henvisninger.
} 
Det er begrensningene i fredspliktens subjektive side som fører til at politiske aksjoner ikke kan anses som arbeidskamp og derfor faller utenfor fredsplikten. Den generelle oppfatningen som er lagt til grunn i ARD 1920-21 s. 1, er at en opptreden som ikke har til formål å påvirke løsningen av en rettstvist eller en interessetvist, ikke kommer i strid med fredsplikten. Det som kjennetegner en politisk aksjon, er følgelig at formålet er noe annet enn å demonstrere sitt syn i en rettstvist eller interessetvist. Dette kan betegnes som at fredsplikten er relativ i sak. Den objektive siden av opptredenen vil imidlertid være lik som ved arbeidskamp. Det er dette som ligger til grunn for karakteristikken «politisk streik». Rettslig sett er imidlertid denne karakteristikken noe misvisende, ettersom en streik er legaldefinert som en arbeidsnedleggelse som har til formål å fremtvinge «løsning av en tvist», jf arbtvl $\S 1$ bokstav f.

At fredsplikten er relativ, er ikke spesielt for norsk kollektiv arbeidsrett. Dette utgangspunktet anerkjennes også i de fleste andre nord-vest-europeiske land. Det er imidlertid mange variasjoner når det gjelder rekkevidden av denne regelen, og det er langt fra selvsagt at det vi i Norge betegner som politiske aksjoner, faller utenfor fredsplikten. ${ }^{12}$ I Tyskland for eksempel er den dominerende oppfatningen at aksjoner med politiske formål ikke er rettmessige. Det samme gjelder i Danmark, hvor formålet med en opptreden i prinsippet er irrelevant. Forstyrrelsen av arbeidsfreden vil i seg selv være et brudd på fredsplikten. ${ }^{13}$ Det hører imidlertid til totalbildet at et brudd på fredsplikten etter dansk rett ikke nødvendigvis fører med seg sanksjoner. I svensk og finsk rett er likhetstrekkene med norsk rett større. I begge disse rettssystemene godtar man i utgangspunktet aksjoner med rent politiske formål. Ut over disse bemerkningene vil jeg ikke gå nærmere inn på fremmed rett. En nærmere unders $\emptyset$ kelse av utenlandsk rett ville fordre mer tid og plass enn det som står til disposisjon her.

\footnotetext{
$12 \quad$ Evju 1985, Nerdrum 1989 s. 151.

13 Hasselbach 1990 s. 37.
} 
At fredsplikten er relativ i sak, innebærer også at politiske demonstrasjoner verken er vernet etter $\mathrm{ESP}^{14}$ eller etter ILO-konvensjonene. ${ }^{15} \mathrm{ESP}$ artikkel $6 \mathrm{nr} .4 \mathrm{om}$ «right to strike» gjelder kun i interessetvister. ILO-konvensjonene har på sin side ingen uttrykkelige bestemmelser om streikeretten, men bygger på det grunnleggende synspunkt at streik er et legitimt og viktig virkemiddel for å forsvare og for å fremme faglige og ervervsmessige interesser. Dette gjelder kort sagt likevel bare lønns- og arbeidsvilkår. ${ }^{16}$

\section{Rettskildegrunnlag, tilnærminger og videre fremstilling}

Arbeidstvistlovene og tariffavtaler gir liten veiledning for hvordan man skal trekke grensen mellom fredsplikten og rettmessige politiske aksjoner. Arbeidsrettens praksis blir derfor den helt sentrale rettskilden. Her finnes det en lang rekke dommer fra ARD 1920-21 s. $1 \mathrm{og}$ fremover. Som tidligere nevnt vil jeg hovedsakelig konsentrere meg om dommer avsagt fra 1989 og frem til i dag. Det er avsagt 13 dommer i dette tidsrommet. For perioden frem til 1989 vil jeg i det vesentlige støtte meg på de dommene Nerdrum behandlet i sin avhandling og i stor grad også bygge på hans drøftelser av dommene. ${ }^{17}$

Nerdrum drøftet politiske aksjoner under fem hovedtilnærminger. Først vurderte han grensen mellom slike aksjoner og opptreden med et for nært forhold til det tariffregulerte, arbeidsgivers styringsrett og et tariffoppgjør (kapittel 2-4). Deretter drøftet han om det kunne oppstilles et krav om begrensninger for politiske aksjoners varighet (kapittel 5), og til slutt vurderte han hvilken betydning aksjonens virkninger kunne ha for rettmessighetsvurderingen (kapittel 6). $\mathrm{Da}$ vurderte han både aksjonens påvirkningsmuligheter på omstendigheter som er underlagt fredsplikt, med andre ord omstendigheter som var behandlet i kapitlene 2-4, og spørsmålet om aksjonens øvrige negative konsekvenser kunne ha betydning for vurderingen av rettmessigheten. Nerdrums

\footnotetext{
14 Den europeiske sosialpakt (1961) (ESP).

15 ILO-konvensjonen nr. 89 (1948), ILO-konvensjonen nr. 98 (1949).

16 NOU 2001: 14 s. 45.

$17 \quad$ Nerdrum 1989.
} 
innfallsvinkler til emnet kan tjene som et utgangspunkt også for min behandling. Det vil imidlertid være viktig å tilpasse fremstillingen til senere rettspraksis, slik at det er denne som blir styrende for opplegget her.

Denne avhandlingen har to hoveddeler. I den første delen, del II, vil jeg gjøre rede for grensen mellom politiske aksjoner og fredspliktens saklige side. Jeg drøfter først hvilke omstendigheter som faller innenfor fredspliktens saklige område: I kapittel 5 behandler jeg spørsmålet om hva som skal regnes som en rettstvist, i kapittel 6 hva som skal regnes som utøvelse av styringsrett, og i kapittel 7 drøfter jeg hva som hører med til fredsplikten i interessetvister. Deretter vil jeg vurdere hvilken sammenheng mellom en aksjon og slike forhold som fører til at opptredenen ikke kan godtas som en rettmessig politisk aksjon (kapittel 8). Det er et poeng at rettmessige politiske aksjoner er negativt definert, ved at aksjonen ikke kan ha for nær tilknytning til noen av de tre nevnte forholdene. Hvis opptredenen ikke er rettmessig etter en slik vurdering, beror det på andre regler enn de som gjelder for politiske aksjoner om opptredenen er berettiget. ARD 1937 s. 22 er et eksempel på dette. Her ble det først drøftet om aksjonen var rettmessig som en politisk aksjon. Arbeidsretten kom til at dette ikke var tilfelle, og tok deretter opp spørsmålet om opptredenen kunne anses som en sympatiaksjon. En detaljert behandling av disse reglene faller imidlertid utenfor det som er denne avhandlingens tema.

Hvis opptredenen derimot kan regnes som en politisk aksjon etter vurderingen av grensen mot fredspliktens saklige område, oppstår spørsmålet om det gjelder ytterligere rettmessighetsvilkår. I del III vil jeg behandle slike mulige vilkår. Først drøfter jeg om det kan oppstilles et vilkår om forhåndsvarsling av demonstrasjonsaksjoner og det eventuelle innholdet av et slikt vilkår (kapittel 10). Deretter vil jeg vurdere i hvilken utstrekning aksjonens varighet og negative konsekvenser, særlig for tariffmotparten, kan få betydning for rettmessighetsvurderingen (kapittel 11). Ettersom politiske aksjoner hittil bare har vært gjennomført av arbeidstakersiden, vil det normalt være arbeidsgiversiden som påføres ulemper ved aksjonen, eksempelvis ved at de påføres et økonomisk tap. Den videre fremstillingen må leses på denne bakgrunn. Prinsipielt er det imidlertid ingenting i veien 
for at også arbeidsgiversiden gjennomfører politiske aksjoner. Dette innebærer at en rekke steder der jeg viser til arbeidstakersiden, også kunne ha vist til arbeidsgiversiden.

En utfordring ved drøftelsen av de forskjellige rettmessighetsvilkårene for politiske aksjoner er at Arbeidsretten ofte foretar en konkret helhetsvurdering av flere tilknytningsfaktorer mellom aksjonen og ulike fredspliktbeskyttede forhold. Det er derfor vanskelig å si noe presist om hva som skal til for at tilknytningen til et av disse forholdene er for nær. Det er også en utfordring at det er avsagt forholdsvis få dommer siden 1989. I denne sammenheng kan det også nevnes at den siste dommen som omhandler grensen mellom politiske aksjoner og fredsplikt, ble avsagt i 2001. Det er følgelig over ti år siden Arbeidsretten sist behandlet det som er tema i denne avhandlingen.

At relativt få påståtte politiske aksjoner er behandlet av Arbeidsretten i de senere år, betyr likevel ikke at slike aksjoner har mistet sin aktualitet som demonstrasjonsmiddel. I 2012 ble det gjennomført flere politiske aksjoner; ett eksempel er demonstrasjonen mot vedtakelsen av det omstridte vikarbyrådirektivet i januar. ${ }^{18}$ Også før 1989 er det på det rene at det ble gjennomført langt flere demonstrasjonsaksjoner enn de som ble brakt inn for Arbeidsretten, jf Nerdrum 1989 s. 150. En mulig grunn til dette kan være at tariffmotparten ikke regner det som økonomisk lønnsomt å reise sak - en rettssak tar tid og koster penger. Særlig kan dette være tilfelle dersom aksjonen allerede er gjennomført og avsluttet og tariffmotparten ikke ble påført noe tap av betydning. Denne begrunnelsen er særlig praktisk for offentlig virksomhet, hvor det hører til unntakene at arbeidsgiver påføres store tap ved en arbeidsnedleggelse blant de ansatte. En annen grunn kan være at tariffpartene frykter at en rettssak kan føre til et dårligere forhold dem i mellom, og mellom deres medlemmer. Det kan igjen føre til et dårligere samarbeid, både på sentralt og lokalt nivå, noe ingen av partene vil være tjent med. ${ }^{19}$

\footnotetext{
18 Europaparlaments- og rådsdirektiv 2008/104/EF av 19. november 2008 om vikararbeid.

19 Nerdrum 1989 s. 150.
} 


\section{Del II: Fredspliktens saklige side}

\section{Introduksjon}

Som jeg har redegjort for foran, er fredsplikten knyttet til tariffavtaler og i første rekke til en bestående tariffavtale. Det grunnleggende kjennetegnet for politiske aksjoner er derimot at de ikke knytter seg til en tariffavtale, eller mer presist: at deres formål ikke er rettet mot en tariffavtale. Dette kan også formuleres som at formålet ikke må knytte seg til «det tariffregulerte». Spørsmålet i denne delen av avhandlingen er hva som skal til for at en aksjon har så nær tilknytning til det tariffregulerte at den ikke kan regnes som en rettmessig politisk aksjon. Først vil jeg behandle spørsmålet om hva som anses å høre med til det tariffregulerte (kapittel 5, 6 og 7). Deretter vil jeg drøfte hvilken tilknytning mellom det tariffregulerte og aksjonen som fører til at en opptreden ikke kan regnes som en rettmessig politisk aksjon (kapittel 8). En viktig problemstilling der er hvordan man avgjør hva aksjonens reelle formål er.

For både rettstvister og interessetvister er utgangspunktet at det gjelder fredsplikt i tariffperioden. Fredsplikten gjelder imidlertid også i den ettervirkningsperioden som oftest følger etter utløpet av en tariffperiode, jf arbtvl $\S 8$ tredje ledd og tjtvl $§ 20$ nr. 2 annet ledd. ${ }^{20}$ Selv om dette utgangspunktet er felles for rettstvister og interessetvister, er det også en viktig forskjell mellom de to. Som jeg tidligere har vært inne på, er fredsplikten i rettstvister absolutt. Dette innebærer at det aldri vil være forenlig med fredsplikten å gjennomføre en demonstrasjon mot en rettstvist. I interessetvister er fredsplikten derimot relativ, både i sak og i tid. Relativiteten i sak innebærer at det som utgangspunkt er adgang til å iverksette arbeidsstans i anledning lønns- og arbeidsvilkår som ikke er regulert av en bestående tariffavtale. Relativiteten i tid innebærer at det som hovedregel bare gjelder

$20 \quad$ Evju 1984 særlig s. 259 flg. 
fredsplikt $\mathrm{i}$ tariffperioden og i ettervirkningsperioden. Utenfor disse periodene er utgangspunktet at arbeidskamp er et legitimt pressmiddel for å få til en løsning av en interessetvist. Det samme gjelder der det ikke har foreligget noen tariffavtale tidligere, jf arbtvl $\S 8$ annet ledd første punktum og tjtvl $\S 20$ nr. 2 første ledd første punktum. Fredspliktens omfang i interessetvister kommer jeg tilbake til i kapittel 7. Først vil jeg se nærmere på spørsmålet om hva som skal regnes som en rettstvist (kapittel 5), og spørsmålet om hvilke beslutninger som skal anses som utøvelse av styringsrett i relasjon til fredsplikten (kapittel 6). 


\section{Rettstvister}

\subsection{Innledning}

Spørsmålet i dette kapittelet er hva som skal anses som en rettstvist, herunder hvordan slike uenigheter skal avgrenses mot omstendigheter som kan gjøres til gjenstand for politiske aksjoner. Når det gjelder uenigheter om tariffrettslige spørsmål, er forutsetningen at de skal løses gjennom rettslige prosedyrer, og ikke gjennom arbeidskamp (jf kapittel 2). Ettersom forutsetningen er at rettslige tvister skal løses rettsveien, har det ingen betydning for bedømmelsen av aksjonen om den aksjonerende part til slutt får medhold i sitt syn på det rettslige spørsmålet. Dette er utvilsomt. Det gjelder heller ingen «resignasjonsplikt» for den part som inntar et standpunkt som vil innebære en endring av rettstilstanden. ${ }^{21}$

Rettstvister er definert i arbtvl $\S 1$ bokstav i og i tjtvl $\S 20$ nr. 1. En type rettstvister er uenighet om en tariffavtales «gyldighet»og «eksistens». Det er vanskelig å se for seg at slike rettstvister kan få betydning for grensen mellom politiske aksjoner og arbeidskamp. Spørsmålet har heller ikke vært behandlet av Arbeidsretten. Jeg går derfor ikke nærmere inn på dette. En annen type rettstvister som derimot har stor betydning for grensen mellom demonstrasjonsaksjoner og fredsplikten, er tvister om en tariffavtales «forståelse» og om «krav som bygger på en tariffavtale». ${ }^{22}$ Den sentrale problemstillingen i dette kapittelet vil være hva som skal til for at det foreligger en slik tvist. Det er på det rene at utfallet av en rettstvist kan få stor betydning for fredspliktens rekkevidde i interessetvister. Dette behandler jeg nærmere i kapittel 7.

\footnotetext{
$21 \quad$ Bjerke 2012.

22 Arbtvl $\S 1$ bokstav i og tilsvarende i tjtvl $\S 20$ nr. 1.
} 


\subsection{Nærmere om rettstvister}

Først og fremst er det klart at uenigheter som hevdes å ha sin løsning i tariffavtalen, er omfattet av fredsplikten i rettstvister. Videre vil en påstand om at motparten har brutt tariffavtalen være en rettstvist. Praksis på dette området er omfattende. Jeg nøyer meg med å vise til tre eksempler fra rettspraksis: ett fra eldre rettspraksis og to fra nyere rettspraksis.

ARD 1985 s. 96 gjaldt grensen mellom en tvist som angikk tariffavtalens forståelse, og omstendigheter som kunne gjøres til gjenstand for politiske aksjoner. Bakgrunn for saken var at Kirke- og undervisningsdepartementet hadde foreslått endringer i undervisningstimetallet for en rekke videregående kurs i yrkesfag og i det maksimale elevantallet for skoleklassene. Som en følge av dette oppfordret Norsk Faglærerlag sine medlemmer til å motsette seg beslutninger fra arbeidsgivers side om å gjennomføre de aktuelle endringene. Faglærerlaget hevdet at opptredenen var rettmessig som en politisk aksjon. Arbeidsretten kom derimot til at aksjonen ikke var rettmessig. Norsk Faglærerlags formål med aksjonen var å få utsatt de aktuelle endringene, og dermed også å få gjennomslag for sitt krav om forhåndsdrøftelser og å ivareta hensynet til lærernes arbeidssituasjon (s. 107). Dette var omstendigheter som var underlagt fredsplikt etter tjtvl $\S 20$ nr. 1. Retten uttalte her at «[i] begge henseender er det således tale om spørsmål som er knyttet til en bestående tariffavtale. Da er det også klart at Faglærerlaget er henvist til å søke spørsmålene løst på annen måte enn gjennom aksjon» (s. 108). At kravene bygget på faglærerlagets forståelse av tariffavtalen, fremgår forutsetningsvis av et brev fra faglærerlaget til departementet hvor det ble hevdet at departementet hadde «oversett informasjonsplikt overfor de berørte lærerorganisasjoner», og av et senere brev der det het at «Norsk Faglærerlag ser svært alvorlig på at Kirke- og undervisningsdepartementet bruter en rekke forutsetninger i sitt brev av 26.02.1985 ...» (s. 99-100; mine kursiveringer).

En nyere dom hvor det også ble viktig at et krav som ble fremsatt ved aksjonen bygget på en forståelse av tariffavtalens bestemmelser, finnes i ARD 1993 s. 147. Her var det spørsmål om en arbeidsnedleggelse gjennomført av Heismontørenes Fagforening (HMF), 
var i strid med fredsplikten. Sakens bakgrunn var at det lenge hadde vært et fallende marked i heisbransjen. HMF hadde derfor jobbet for inngåelse av lokale avtaler om bruk av rullerende permitteringer fremfor oppsigelser. Ved en del av bedriftene ble det inngått slike lokale avtaler. En av disse bedriftene var Kone Heis AS. På tross av avtaleinngåelsen gikk Kone til oppsigelser av 16 ansatte. Det oppstod uenighet mellom partene om berettigelsen av oppsigelsene på grunnlag av den lokale avtalen. Den 20. oktober 1992 varslet HMF en politisk demonstrasjon mot «NHOs sysselsettingspolitikk og støtte til KONE klubben». ${ }^{23}$ Arbeidsretten kom til at opptredenen ikke var rettmessig som en politisk aksjon. Et viktig argument for dette var at arbeidsnedleggelsen var rettet mot NHO og bransjeorganisasjonenes syn på anvendelsen av avtaleverket angående spørsmålet om bruk av rullerende permitteringer (s. 169). Et annet moment var at aksjonen var knyttet til oppsigelsene ved bedriften Kone, som arbeidstakersiden hevdet at innebar et brudd på tariffavtalen (s. 170).

Også ARD 1989 s. 165 er et eksempel på at en «politisk aksjon» hadde til formål å reagere mot et påstått tariffbrudd hos motparten. Arbeidsretten kom til at oppfordringer fra Norsk Sykepleierforbund til deres medlemmer om å motsette seg gjennomføring av beslutninger fra arbeidsgivers side, var i strid med fredsplikten. Den nærmere bakgrunn for saken var at det pågikk et prøveprosjekt ved Regionsykehuset i Tromsø, som gikk ut på å utvikle og å prøve nye organisasjonsformer for ledelse av sykehusavdelinger. Arbeidsgiver hadde i denne forbindelse foretatt en rekke ansettelser i lederstillinger ved sykehuset. Arbeidsretten kom til at Norsk Sykepleierforbunds aksjon var en reaksjon mot ansettelsesvedtakene. Begrunnelsen for dette var dels arbeidstakersiden mente at vedtakene var i strid med en lokal tariffavtale. Aksjonen var også rettet mot den fremtidige ansettelsespolitikk. Arbeidsretten fant at det var «åpenbart» at formålet med aksjonen var i strid med fredsplikten (s. 171).

Som dette viser, er krav som bygger på eller angår forståelsen av tariffavtalen underlagt fredsplikt. Det er ingen tvil om at slike tariffrettslige spørsmål ikke kan gjøres til gjenstand

23 Se innkallelsen til demonstrasjonen av 20. oktober 1992 gjengitt på dommens s. 152. 
for rettmessige politisk aksjoner. Et annet spørsmål er om det vil være forenlig med fredsplikten å demonstrere sitt syn på rettsregler utenfor tariffavtalen. Spørsmålet blir om det også i slike tilfeller kan foreligge en tilknytning til tariffavtalen som fører til at forholdet er underlagt fredsplikt. Et eksempel på at et slikt spørsmål ble ansett for å falle utenfor fredsplikten, gir ARD 1979 s. 37. Her kom Arbeidsretten til at en demonstrasjon mot arbeidsgivers beslutning om å bevilge penger til politiske partier, var forenlig med fredsplikten. Et annet eksempel er ARD 1976 s. 23, hvor en aksjon mot bystyrets beslutning om ikke å bifalle Ungdomskontorets forslag til budsjett, ikke ble ansett for å være i strid med fredsplikten. I rettspraksis er det også eksempler på at rettslige spørsmål som ikke kan løses på grunnlag av tariffavtalen, har blitt ansett for å falle innenfor fredspliktens ramme. Det har for eksempel lang tradisjon at det ikke er adgang til å gå til aksjon mot arbeidsgivers beslutninger om oppsigelser og avskjed. Rt. 1977 s. 902 er en illustrasjon av dette. I denne dommen måtte Høyesterett prejudisielt ta stilling til om gjennomføringen av en arbeidsnedleggelse blant arbeidstakere ved Norsk Hammerverk var rettmessig. Arbeidsnedleggelsen ble gjennomført som protest mot en oppsigelse i bedriften. Retten kom til at opptredenen ikke var rettmessig, og det ble vist utførlig til Arbeidsrettens praksis (s. 914). Spørsmålet om det vil være forenlig med fredsplikten å demonstrere et syn på rettsregler utenfor tariffavtalen, er primært et spørsmål om rekkevidden av arbeidsgivers styringsrett. Det behandler jeg i neste kapittel.

Det må her tas et forbehold for tilfeller hvor arbeidstakerne nekter å utføre arbeid på grunn av en frykt for «påtagelig helsefare». ${ }^{24}$ Det følger av Arbeidsrettens praksis at en nektelse av å utføre arbeidet av sikkerhetsmessige årsaker kan være forenlig med fredsplikten. Oppfatningen har imidlertid grunnlag i nødrettsbetraktninger, ${ }^{25}$ og bygger følgelig ikke på skillet mellom politiske aksjoner og fredspliktens saklige side. Jeg går derfor ikke nærmere inn på dette spørsmålet.

Evju 1990 s. 255.

ARD 1972 s. 89 s. 105. 


\section{Beslutninger som faller innenfor arbeidsgivers styringsrett}

\subsection{Innledning}

Det er vanlig å si at arbeidsgivers styringsrett er arbeidsgivers rett til «å organisere, lede og fordele arbeidet, og til å ansette og si opp arbeidstakere». ${ }^{26}$ Denne forståelsen kan tjene som et utgangspunkt her. Spørsmålet er imidlertid hvordan man skal trekke grensen mellom arbeidsgivers styringsrett og forhold som kan gjøres til gjenstand for politiske aksjoner. Det er ikke gitt at styringsrettens innhold er det samme i forhold til fredsplikten som $i$ andre sammenhenger.

Tariffavtaler bygger på en alminnelig forutsetning om at arbeidsgiver har en styringsrett. I dette ligger det for det første at arbeidsgiver kan treffe beslutninger innenfor rammen av det som er tariffregulert, men også at det kan tas avgjørelser om rettslig spørsmål som ikke er direkte tariffregulert. Det er ikke vanlig at det fremgår uttrykkelig av tariffavtalen at arbeidsgiver har en slik styringsrett. Likevel er begrunnelsen for at arbeidsgivers utøvelse av styringsrett er underlagt fredsplikt, at den anses som en del av tariffavtalens regulering. Dette kan uttrykkes som at tariffavtalen innebærer en helhetlig regulering av rettslige spørsmål i tariffperioden. ${ }^{27}$ Den grunnleggende dommen på dette punkt er ARD 1922 s. $86 .{ }^{28}$ Men som eksemplene mot slutten av forrige kapittel viser, er det ikke alle beslutninger fra arbeidsgivers side som er underlagt fredsplikt.

\footnotetext{
26 Andersen 1967 s. 67, m.fl.

27 Det er imidlertid full adgang til å gå til arbeidskamp for å få regulert begrensninger i arbeidsgivers utøvelse av styringsrett når adgangen til arbeidskamp i interessetvister står åpen. Fra nyere praksis kan det vises til ARD 2001 s. 382.

28 Ut fra voldgiftsdommene som ble avsagt tidlig på 1920-tallet, var det diskutabelt om arbeidsgivers styringsrett var underlagt fredsplikt, jf Knoph 1921 s. 128-134. Etter dommen i ARD 1922 s. 86 var det imidlertid ikke lenger tvil om dette var forhold som hørte med til fredsplikten.
} 
Det første spørsmålet jeg vil drøfte i dette kapittelet, er hvilke beslutninger som saklig sett kan karakteriseres som utøvelse av styringsrett. Et neste spørsmål, som særlig har vært oppe i nyere rettspraksis, er betydningen av hvem som tar beslutningen. Et sentralt spørsmål er her om andre enn de aksjonerende parters arbeidsgiver kan utøve styringsrett i relasjon til fredsplikten.

\subsection{Beslutninger som etter sin art er utøvelse av styringsrett}

Det rettslige grunnlaget for at beslutninger som hører til arbeidsgivers utøvelse av styringsrett er underlagt fredsplikt, er som det fremgår overfor at styringsretten anses som en del av tariffavtalens regulering. Det er derfor naturlig at det kun er beslutninger med tilknytning til tariffregulerte forhold, som er underlagt fredsplikt. Dette fremgår av ARD 1979 s. 37. Som nevnt foran i kapittel 5 avsnitt 5.2, kom Arbeidsretten her til at arbeidsgivers beslutning om å bevilge penger til et politisk parti, ikke var underlagt fredsplikt. Som begrunnelse uttalte retten følgende:

«Arbeidsnedleggelsene tar - i den utstrekning de måtte bli aktuelle - ikke sikte på forhold som direkte eller indirekte er tariffrettslig regulert. De er eksklusivt rettet mot eventuelle beslutninger fra bedriftens side om å bevilge penger til politiske partier, og disse beslutningene har overhodet intet med overenskomstordnede forhold å gjøre» (s. 42). ${ }^{29}$

Det stilles således krav om en sammenheng mellom beslutningens innhold og tariffavtalen, for at beslutningen skal være underlagt fredsplikt. På den annen side stilles det ikke krav om at den omstendighet beslutningen angår, er uttrykkelig regulert i tariffavtalen. Styringsretten er jo nettopp et eksempel på at andre forhold enn de som uttrykkelig fremgår av tariffavtalen, kan falle inn under fredsplikten. Det sentrale spørsmålet i dette avsnittet er hva som ligger i kravet til sammenheng med tariffavtalen.

29 Retten drøftet ikke arbeidsgivers styringsrett uttrykkelig, men styringsretten må anses behandlet implisitt jf Nerdrum 1989 s. 176. 
På bakgrunn av rettspraksis kan det oppstilles noen sikre typetilfeller som utvilsomt må anses som utøvelse av styringsrett i relasjon til fredsplikten. Et fellestrekk ved disse beslutningene er at de angår arbeidstakeres lønns- og arbeidsvilkår direkte. Det første eksempelet jeg vil nevne er ARD 1989 s. 165. Arbeidsretten la til grunn at formålet med aksjonen var å ramme arbeidsgivers ansettelsesvedtak. Retten uttalte at det var «åpenbart» at formålet var uforenlig med fredsplikten (s. 174). Andre eksempler er ARD 1989 s. 47 og ARD 1990 s. 180. I begge dommene gjaldt beslutningene bemanning og organisering av arbeidet. I den første av dommene var det dominerende formålet å fremtvinge endringer i arbeidsgivers beslutning om å redusere bemanningen fra 24 timers til 12 timers vakt. Den andre dommen gjaldt en beslutning om fordeling av ulike typer arbeid mellom ulike stillinger i bedriften. Det siste eksempelet jeg vil trekke frem her, er ARD 1997 s. 193. Bakgrunnen for saken var at Kirke-, utdannings- og forskningsdepartementet hadde sendt ut et rundskriv hvor det ble bedt om at fylkeskommunene tok ansvar for innføring av opplæringsbok i den videregående skole. Opplæringsboken skulle være et hjelpemiddel for lærerne ved utførelsen av deres arbeid. Lærerforbundet oppfordret sine medlemmer til å motsette seg bruk av opplæringsboken. Arbeidsretten kom til at beslutningen om å innføre opplæringsboken falt innenfor fredsplikten fordi den angikk spørsmålet om hvordan arbeidsoppgavene skulle ivaretas.

Felles for beslutningene i de sakene som er omtalt her, er at de hører til det Evju betegner som arbeidsledelse. ${ }^{30}$ Det typiske for slike beslutninger er at de bygger på en form for heteronom kompetanse - en kompetanse til å fastsette normer med bindende virkning for andre. Også ut fra eldre rettspraksis var det klart at beslutninger som kunne karakteriseres som arbeidsledelse som hovedregel var omfattet av fredsplikt. ${ }^{31}$ Det kan ikke legges til grunn at det er skjedd noen endring av rettspraksis på dette punkt. Eksempler fra tidligere rettspraksis er ARD 1958 s. 125, hvor arbeidsgivers fastsettelse av arbeidstidens omfang og plassering ble ansett beskyttet av fredsplikt, og ARD 1981 s. 117, hvor arbeidsgivers oppsigelser ble ansett omfattet av fredsplikten.

\footnotetext{
$30 \quad$ Evju 2003 s. 16.

$31 \quad$ Nerdrum 1989 s. 166 flg og 178.
} 
Spørsmålet om hva som skal til for at andre beslutninger rammes av fredsplikt, er mer tvilsomt. Evju betegner slike beslutninger som foretaksledelse. ${ }^{32}$ Det kan ikke oppstilles noe klart skille mellom beslutninger som kan anses som arbeidsledelse og foretaksledelse. For beslutninger som hører til foretaksledelsen, er det typiske imidlertid at de bygger på arbeidsgivers autonome kompetanse - en kompetanse til å fastsette normer med bindende virkning for seg selv. Evju fremholder at grunnlaget for å anse slike beslutninger som utøvelse av styringsrett, vil være de indirekte konsekvenser de får for arbeidstakerne. Evju drøftet imidlertid ikke distinksjonen mellom arbeidsledelse og foretaksledelse konkret i relasjon til fredsplikten. Men det fremgår av både eldre og nyere rettspraksis at også slike beslutninger kan være beskyttet av fredsplikt. ${ }^{33}$

Nyere rettspraksis gir to eksempler på dette: ARD 1995 s. 34 og ARD 2001 s. 243. ARD 1995 s. 34 gjaldt en arbeidsnedleggelse blant ansatte i AS Oslo Sporveier. Bakgrunnen var at Oslo Sporveier hadde inngått en intensjonsavtale med Swebus AS om mulig utskillelse av bussdivisjonen i Oslo Sporveier og om videresalg av aksjer i det nye selskapet til Swebus. Arbeidsretten bemerket at spørsmål om «forhandlinger om og inngåelse av avtaler» utvilsomt hørte med til arbeidsgivers styringsrett i relasjon til fredsplikten (s. 46). Isolert sett kan denne uttalelsen gi inntrykk av at enhver avtaleinngåelse fra bedriftens side omfattes av fredsplikten. Uttalelsen ble ikke nærmere begrunnet, og retten ga ikke uttrykk for reservasjoner. Det er derfor vanskelig å slutte noe ut fra dommen på dette punkt uten å se den i sammenheng med annen praksis.

Til tross for protestene fra arbeidstakerne i ARD 1995 s. 34, ble bussdivisjonen i Oslo Sporveier skilt ut som et eget aksjeselskap - AS Sporveisbussene, men med Oslo Sporveier som eneeier. Noen år senere oppsto det imidlertid spørsmål om Oslo Sporveier skulle selge seg ut av datterselskapet. Det var foranledningen til en ny påstått politisk aksjon, som ble behandlet i ARD 2001 s. 243. Et sentralt spørsmål var da om Oslo Sporveiers beslutning

\footnotetext{
$32 \quad$ Evju 2003 s. 17.

33 Om eldre praksis vises det til Nerdrum 1989 s. 169 flg.
} 
om å selge aksjene i Sporveisbussene kunne anses som utøvelse av styringsrett overfor de ansatte i Sporveisbussene. Arbeidsretten kom til at dette var tilfelle. De sentrale momentene ved vurderingen var at beslutningen kun gjaldt Sporveisbussene, og at den kunne få «vidtrekkende konsekvenser» for bedriften og dens ansatte. At en beslutning kan få konsekvenser for de ansatte, er likevel ikke alltid tilstrekkelig til at beslutningen etter sin art kan anses som utøvelse av styringsrett. Det fremgår forutsetningsvis av ARD 1989 s. 134. I den saken var det spørsmål om et vedtak fra bankforeningene om å nedlegge Bankakademiet, en utdanningsinstitusjon for ansatte i banker, var underlagt fredsplikt. Arbeidsretten vurderte både om beslutningen kunne karakteriseres som utøvelse av styringsrett, og om beslutningen hadde så nær sammenheng med en fremtidig tariffavtaleregulering, at den var underlagt fredsplikt. Begrunnelsen for at beslutningen ikke kunne anses som utøvelse av styringsrett, var dels at beslutningen etter sin art ikke kunne anses som utøvelse av styringsrett, og dels at bankforeningene ikke kunne identifiseres med bankene som arbeidsgivere (s. 147). Den viktigste av disse to begrunnelsene var at beslutningen etter sin art ikke kunne anses som utøvelse av styringsrett fordi kompetansen til å ta avgjørelsen ikke bygget på tariffavtalen. At dette var den viktigste begrunnelsen, fremgår av bemerkningen om at bankforeningene «heller ikke» kunne identifiseres med bankene som arbeidsgivere (s. 147). Bruken av uttrykket heller ikke tyder på at dette var en tilleggsbegrunnelse til setningen foran, hvor det ble bemerket at kompetansen til å ta beslutningen ikke bygget på tariffavtalen. Ved vurderingen av om kompetansen bygget på tariffavtalen, ble det lagt vekt på at Bankakademiet ikke var en tariffbasert institusjon. Grunnen til dette var at etableringen av akademiet bygget på et rettsgrunnlag utenfor tariffavtalen, og at institusjonen var regulert gjennom egne vedtekter. Det ble ikke lagt vekt på at beslutningen rent faktisk kunne få betydning for tariffregulerte forhold selv om en slik mulighet utvilsomt var til stede. ${ }^{34}$

34 Se uttalelsen om at «avvikling av Bankakademiet ville ha direkte innvirkning på anvendelsen av bankoverenskomstens bestemmelser om rettigheter til og rettsvirkningen av utdannelse ved institusjonen», og videre at «[o]m det ikke var ubetinget nødvendig, ville det i hvert fall være i høy grad aktuelt å revidere overenskomstens bestemmelser» (s. 148). 
Det kan stilles spørsmål om hvorfor det ble lagt vekt på beslutningens virkning for arbeidstakerne i 2001-dommen, mens dette ikke ble vektlagt i 1989-dommen. Det er lite sannsynlig at momentet ble oversett i ARD 1989 s. 134 ettersom beslutningens virkninger for arbeidstakerne var et viktig moment $\mathrm{i}$ en annen del av rettens vurdering (s. 148). Et forhold som imidlertid skiller ARD 2001 s. 243 fra ARD 1989 s. 134, er hvor direkte beslutningen angikk arbeidsgiverbedriften. I 2001-dommen angikk beslutningen arbeidsgiverbedriften konkret, herunder dens forhold til sine medkontrahenter. Mens i ARD 1989 s. 134 angikk beslutningen en utdanningsinstitusjon uten noen organisatorisk tilknytningen til arbeidsgiverbedriften. Beslutningen der kunne også få konsekvenser for andre arbeidsgivere enn de som tariffavtalen hadde virkning for. Også i ARD 1995 s. 34 angikk beslutningen arbeidsgiverbedriften på en langt mer direkte måte enn i ARD 1989 s. 134. En annen grunn til at ARD 1989 s. 134 ble vurdert annerledes enn ARD 1995 s. 34 og ARD 2001 s. 243, kan være at det i 1989-dommen ikke var grunnlag for identifikasjon mellom beslutningstakeren og arbeidsgiver. Selv om det ikke fremgår uttrykkelig av rettens premisser i ARD 1989 s. 134, kan man ikke utelukke at dette faktum innebar at det ble stilt strengere krav til beslutningens art, for at den skulle anses som utøvelse av styringsrett.

Det er etter dette vanskelig å si noe sikkert om hva som skal til for at en beslutning kan anses som utøvelse av styringsrett utenfor de sikre typetilfellene. Dette beror på en konkret helhetsvurdering. I denne vurderingen vil man måtte se hen til beslutningens virkning for arbeidstakerne og arbeidsgiverbedriften og hvor direkte beslutningen angår arbeidsgiverbedriften. Jo større grad av disse momentene som er til stede, jo mer nærliggende vil det være å si at beslutningen har sammenheng med tariffavtalen. Jeg vil nå vurdere hvordan de tre dommene som er gjennomgått til nå stiller seg i forhold til tidligere rettspraksis.

ARD 1979 s. 37 er en dom fra eldre rettspraksis hvor beslutningen i svært liten grad kunne få betydning for arbeidstakerne. Her ble arbeidsgivers beslutning om å bevilge penger til et politisk parti, ansett å falle utenfor fredspliktens rammer. Selv om beslutningen angikk 
arbeidsgiverbedriften direkte og konkret, var det lite sannsynlig at den kunne få virkning for arbeidstakerne. To andre dommer fra eldre rettspraksis hvor det ble vurdert om en beslutning som det kan være naturlig å betegne som foretaksledelse kunne anses som utøvelse av styringsrett, er ARD 1937 s. 22 og ARD 1985 s. 40. I den første av disse dommene hadde Sjømannsforbundet oppfordret sine medlemmer til å kreve seg avmønstret fra skip i havner som ble kontrollert av general Franco i Spania. Arbeidsretten kom til at disse oppfordringene ikke kunne regnes som en rettmessig politisk aksjon fordi de var rettet mot redernes rett til å disponere sine skip (s. 26). Redernes myndighet til å avgjøre hvilke skip som skulle gå hvor, var følgelig underlagt fredsplikt. Etter min vurdering ville det også i dag være naturlig å karakterisere en slik beslutning som utøvelse av styringsrett fordi beslutningen ville ha store konsekvenser for arbeidsgiverbedriften og de ansatte der. Det samme gjelder ARD 1985 s. 40 hvor arbeidsgivers avgjørelse om endret driftsopplegg for bedriften, var omfattet av fredsplikt. Beslutningen angikk arbeidsgiverbedriften direkte og ville videre få store konsekvenser for de ansatte. Det er følgelig ikke grunn til å hevde at rettstilstanden har endret seg når det gjelder spørsmålet om hva som skal til for at en beslutning etter sin art kan anses som styringsrett i relasjon til fredsplikten.

\subsection{Hvem kan utøve styringsrett}

\subsection{De aksjonerendes arbeidsgiver}

Ved vurderingen av om en beslutning kan anses som utøvelse av styringsrett, kan det ha betydning hvem som har tatt beslutningen. Dette er tema i det følgende. Arbeidsrettens praksis viser at ikke enhver kan anses for å utøve styringsrett i relasjon til fredsplikten. For det første kan det oppstå tvil om hvem (typisk hvilken bedrift) som skal anses som de aksjonerende parters egentlige arbeidsgiver. Dette spørsmålet må løses ut fra en konkret vurdering. Et eksempel fra den individuelle arbeidsrett er Rt. 1993 s. 490. Høyesterett kom til at den bedriften som gjennomførte ansettelsesprosessen, måtte anses for å være arbeidsgiver, selv om vedkommende mente å opptre som fullmektig for et annet selskap. Begrunnelsen var at fullmektigen ikke på en tilstrekkelig klar måte hadde gitt uttrykk for at 
han ikke skulle være arbeidsgiver. Så vidt jeg kan se har problemstillingen ikke kommet på spissen i relasjon til grensedragningen mellom fredsplikten og politiske aksjoner.

En annen form for tvil kan knytte seg til hvem $i$ bedriften som kan anses for å handle på vegne av selskapet. Her ligger det nær å ta utgangspunkt i selskapsrettens regler om hvem som har slik kompetanse. En generell gjennomgang av disse reglene vil føre for langt for fremstillingen her. Noen hovedlinjer kan imidlertid nevnes. Først og fremst er det ingen tvil om at bedriftens ledende organer, herunder styret og generalforsamlingen, kan utøve styringsrett. I en rekke dommer har Arbeidsretten ansett en beslutning som har vært truffet av bedriftsledelsen eller av selskapets styre, for å falle innenfor arbeidsgivers styringsrett. ${ }^{35}$ En klar uttalelse om dette finnes i ARD 1995 s. 34, hvor det ble uttalt at «enn mindre er det etter de alminnelige fredspliktnormer noen adgang til arbeidsnedleggelse knyttet til behandlingen av saker $i$ et aksjeselskaps ledelse eller styrende organer» (s. 46). Det er likevel ikke bare de ledende selskapsorganene som kan ha kompetanse til å handle på vegne av selskapet. I større bedrifter er det for eksempel vanlig at selskapet har en administrasjonsavdeling, som har kompetanse til å ta beslutninger av mindre betydning for selskapet enn de beslutninger som må tas i de ledende organer. Det ville være unaturlig om slike beslutninger ikke var underlagt fredsplikt, ettersom det ligger i administrasjonens rolle at de handler på vegne av selskapet. Administrasjonens kompetanse til å ta beslutninger på vegne av selskapet, kan bygge direkte på deres stillingsfullmakt eller på et konkret vedtak i selskapets ledende organer. Dette siste var tilfelle i ARD 1985 s. 40, hvor styret fattet vedtak som påla administrasjonen å gjennomføre en omlegging av selskapets drift. I saken ble ikke bare styrevedtaket, men også administrasjonens oppfølging av det ansett for å være underlagt fredsplikt. Det er heller ingenting i veien for at enkeltpersoner utøver styringsrett, enten ansatte eller andre som utfører et oppdrag for selskapet. Forutsetningen er imidlertid at vedkommende avleder sin kompetanse til å handle fra selskapet.

35 Jf eksempelvis ARD 1935 s. 132, ARD 1953 s. 48, ARD 1990 s. 180. 


\subsection{Særlig om politiske organers/ personers deltakelse ved beslutningen}

Politikere eller politiske organer kan ha kompetanse til å utøve styringsrett i kraft av ulike former for tilknytning til arbeidsgivervirksomheten: virksomheten kan være organisert som forvaltningsorgan, det kan være grunnlag for identifikasjon mellom et politisk organ og arbeidsgiver etter drøftelsen i punkt 6.33, eller politikere kan være representert i virksomhetens styrende organer. Betydningen av denne siste tilknytningsformen kommer på spissen der arbeidsgivervirksomheten ikke er organisert som forvaltningsbedrift. I alle disse tilfellene oppstår det spørsmål om hvordan man skal trekke grensen mellom vedkommendes disposisjoner som politiker eller politisk organ og vedkommendes utøvelse av styringsrett i relasjon til reglene om fredsplikt. Problemstillingen har nær sammenheng både med spørsmålet om hvem som kan utøve styringsrett, og med spørsmålet om hvilke beslutninger som etter sin art kan anses som utøvelse av styringsrett. Poenget er at forhold ved den konkrete beslutningen får direkte betydning for grensedragningen mellom utøvelse av politisk kompetanse og utøvelse av styringsrett.

Problemstillingen illustreres særlig godt i ARD 2001 s. 88. I saken var det spørsmål om Stortingets behandling av en stortingsproposisjon om fremtidig eierskap i Statoil kunne anses som utøvelse av styringsrett overfor de ansatte i Statoil. Det mulige grunnlaget for identifikasjon mellom Statoil og Stortinget lå i at staten var eneeier i Statoil. Identifikasjonsspørsmålet ble imidlertid ikke drøftet av retten. Spørsmålet om Stortingets behandling kunne anses som utøvelse av styringsrett, ble avgjort på grunnlag av en sondring mellom Stortingets rolle som konstitusjonelt organ og statens rolle som eier av Statoil. Retten kom til at beslutningen knyttet seg til Stortingets rolle som konstitusjonelt organ, og det var da ikke treffende å karakterisere behandlingen av forslagene i stortingsproposisjonen som utøvelse av styringsrett (s. 103). Det gjaldt selv om Stortinget ikke ville hatt kompetanse til å ta beslutningen dersom staten ikke var eier av Statoil. Dette ble imidlertid ikke kommentert av retten. At behandlingen hadde grunnlag i Stortingets konstitusjonelle rolle, ble begrunnet med de interesser beslutningen bygget på. Her skilte Arbeidsretten mellom selskapsinteresser og «overordnede spørsmål av blant annet 
finanspolitisk og oljepolitisk karakter» (s. 103). De interesser som lå bak Stortingets beslutning, ble følgelig avgjørende for grensedragningen.

Også i ARD 1995 s. 34 ble det trukket et skille mellom beslutningstakernes kompetanse som politikere og deres kompetanse til å ta beslutninger som kunne innebære utøvelse av styringsrett. Politikernes kompetanse til å utøve styringsrett hadde grunnlag i at de var representert i arbeidsgiverbedriftens styrende organer. Arbeidsretten bemerket at spørsmål om forhandling om og inngåelse av avtaler, utvilsomt var omfattet arbeidsgivers styringsrett i relasjon til fredsplikten, og videre at «[i] en slik sammenheng har det heller ikke betydning om selskapets organer er politisk valgt eller består av personer som også er representanter i politiske organer» (s. 46). Den første uttalelsen må utvilsomt anses som en henvisning til beslutningens art. De to uttalelsene sett i sammenheng gir derfor grunnlag for å anta at dersom en beslutning formelt er tatt av arbeidsgiverbedriften, og etter sin art er å anse som styringsrett, har det ikke betydning at politikere har deltatt $\mathrm{i}$ beslutningen ved å være en del av arbeidsgiverbedriftens organer. I motsetning til i ARD 2001 s. 88 ble det ikke uttrykkelig sondret mellom hvilke hensyn beslutningstakerne bygget på ved beslutningen. Det ligger imidlertid implisitt $i$ at en beslutning som tas av et selskaps styre, bygger på selskapets interesser.

Som begrunnelse for uttalelsen i ARD 1995 s. 34 på s. 46, ble det vist til ARD 1994 s. 272. I dommen fra 1994 ble aksjonen ansett rettet mot tariffregulerte forhold knyttet til virkningen av et generalforsamlingsvedtak i arbeidsgiverbedriften. Retten bemerket at det ikke satte saken i noen annen stilling at generalforsamlingen besto av medlemmer av kommunens formannskap (s. 281). Begrunnelsen var at vedtaket ble truffet av generalforsamlingen som selskapsorgan. Så vidt jeg kan se var henvisningen til at beslutningen var truffet av generalforsamlingen som selskapsorgan, ikke nødvendig for å begrunne at aksjonen var i strid med fredsplikten. Det fremgår av at aksjonen var urettmessig fordi det i tariffperioden ble demonstrert mot mulige endringer i det tariffregulerte, ved at aksjonen knyttet seg til virkningene generalforsamlingsvedtaket ville 
ha for den bestående reguleringen av lønns- og arbeidsvilkår. ${ }^{36}$ Dommen tilsier likevel at det må trekkes en grense mellom utøvelse av kompetanse på politisk grunnlag og utøvelse av styringsrett.

Etter eldre rettspraksis var det også et visst grunnlag for å sondre mellom beslutningstakerens rolle som politiker og dennes kompetanse til å utøve av styringsrett. Det illustreres av ARD 1976 s. 23 og ARD 1976 s. 96. I den første av disse dommene var det spørsmål om en aksjon blant arbeidstakerne i et underliggende forvaltningsorgan mot budsjettbehandling i Oslo bystyre, var i strid med fredsplikten. Retten mente at det ut fra vanlige arbeidsrettslige synspunkter ikke var naturlig å anse beslutningen som utøvelse av styringsrett og bemerket at det måtte sondres mellom slik styringsrett og «folkevalgte bystyremedlemmers alminnelige avgjørelsesmyndighet på det samlede budsjettpolitiske plan» (s. 38). Sondringen ble også anvendt i ARD 1976 s. 96 på finansrådmannens og finansutvalgets budsjettforslag. Siden begrunnelsene i de to 1976-dommene var svært konkret utformet, gir de i beste fall et spinkelt grunnlag for å vurdere andre offentlige vedtak enn fylkeskommunale og statlige budsjettvedtak. ${ }^{37}$ På dette punkt har ARD 1995 s. 34 og ARD 2001 s. 88 bidratt til en avklaring av grensen mellom offentlig myndighetsutøvelse og utøvelse av styringsrett. Dommene viser at et viktig moment i denne vurderingen er hvilke hensyn som ligger til grunn for beslutningen.

Det har tidligere vært reist spørsmål om det må trekkes en grense mellom politikeres generelle avgjørelsesmyndighet og deres standpunkttagen til enkeltspфrsmål, i den forstand at det første i større grad faller utenfor styringsretten enn det siste. ${ }^{38}$ Ut fra eldre rettspraksis var det usikkert om det kunne oppstilles et slikt skille. Imidlertid kunne premissene i ARD 1976 s. 23 tilsi at generelle avgjørelser i større grad enn enkeltavgjørelser falt utenfor styringsretten. ${ }^{39}$ Arbeidsretten viste her til at det måtte

\footnotetext{
$36 \quad$ Se nærmere kapittel 7 avsnitt 7.2.

37 Nerdrum 1989 s. 172.

38 Nerdrum 1989 s. 172.

39 Nerdrum 1989 s. 172.
} 
sondres mellom «styringsrett på den ene side og folkevalgte bystyremedlemmers generelle avgjørelsesmyndighet på det samlede budsjettpolitiske plan» (s. 38; min kursivering). Heller ikke med den praksis som foreligger i dag, kan det sies sikkert om generelle politiske avgjørelser i større grad faller utenfor fredsplikten enn enkeltavgjørelser. I ARD 1995 s. 34 gjaldt beslutningen et enkeltspørsmål, og retten kom til at beslutningen var omfattet av styringsretten. Sondringen mellom generelle og spesielle avgjørelser ble imidlertid ikke uttrykkelig trukket frem. I ARD 2001 s. 88 var beslutningen av mer generell karakter. Ved begrunnelsen av at beslutningen falt utenfor arbeidsgivers styringsrett, la retten vekt på at beslutningen gjaldt «overordnede spørsmål ...» (s. 103). Dette tyder på at det var et moment i rettens vurdering at beslutningen var av generell karakter. Dommen kan dermed sies å gå i samme retning som ARD 1976 s. 23. Et forhold som kan tilsi at generelle avgjørelser i større grad enn enkeltavgjørelser faller utenfor fredsplikten, er at det bak generelle avgjørelser oftere vil ligge utpregede politiske hensyn enn det som vil være tilfelle for enkeltavgjørelser. Det innebærer imidlertid ikke at det har avgjørende rettslig betydning hvorvidt man har å gjøre med en enkeltavgjørelse eller en generell avgjørelse. Dette, i tillegg til at sondringen har svakt grunnlag i rettspraksis, innebærer at man bør være varsom med å tillegge sondringen vesentlig betydning. Det avgjørende for vurderingen av grensen mellom politiske spørsmål og utøvelse av styringsrett bør være en konkret vurdering av de hensyn den aktuelle beslutningen bygger på.

\subsection{Identifikasjon}

Jeg vil nå drøfte hvilken betydning det har for om en beslutning kan anses som utøvelse av styringsrett at den er tatt av andre enn de aksjonerende parters arbeidsgiver. Forutsetningen er dermed at beslutningen ikke kan anses for å være tatt av de aksjonerendes egen arbeidsgiver, og at beslutningen ikke må anses for å være tatt av et politisk organ i utøvelsen av dets rolle som politisk organ. ${ }^{40}$ I slike tilfeller som behandles her blir spørsmålet om beslutningen likevel kan være omfattet av fredsplikt. Som utgangspunkt

40 I sistnevnte tilfelle vil den jo ikke kunne anses som utøvelse av styringsrett, jf punkt 6.32. 
tilligger styringsretten arbeidsgiver. Umiddelbart kan det derfor synes noe fremmed at andres beslutninger kan være underlagt fredsplikt. Praksis viser likevel ett eksempel på at en slik avgjørelse var omfattet av fredsplikt. Før jeg går over til å behandle denne dommen, vil jeg si litt om grunnlaget for identifikasjon mellom arbeidsgivere «innenfor samme tarifforhold».

Med arbeidsgivere «innenfor samme tarifforhold» sikter jeg til arbeidsgivere som er bundet av samme tariffavtale ved å være medlemmer i samme organisasjon. Det er klart at arbeidstakerorganisasjonens plikt til å overholde fredsplikten gjelder overfor alle medlemsbedriftene i arbeidsgiverorganisasjonen. Det fremgår også av ARD 1989 s. 165, hvor det var iverksatt en aksjon av Norsk Sykepleierforbund. Arbeidsretten bemerket at det ikke var avgjørende om tiltakene ikke kunne anses som rettet mot Regionsykehuset i Troms $\varnothing$ spesielt, men mot ansettelsespolitikken ved sykehus generelt (s. 174). Dette ble begrunnet med at tariffavtaleforholdet mellom Norsk Sykepleierforbund og deres tariffmotpart omfattet flere sykehus, og videre med at aksjoner som tilsiktet å virke inn på «andre arbeidsgivere som er bundet av tariffavtalene», ville være i strid med fredsplikten. Mer tvilsomt er spørsmålet dersom en fagforening ved en enkelt bedrift iverksetter en aksjon som tar sikte på å virke inn på andre arbeidsgivere enn deres egen. Da de aksjonerende arbeidstakerne er underlagt samme tariffavtale som bedriftene de aksjonerer mot, vil demonstrasjonen i realiteten angå deres egen tariffavtale. Det taler for at utøvelse av styringsrett hos andre arbeidsgivere innenfor samme tarifforhold er underlagt fredsplikt. Et mer spesielt spørsmål er om det kan være i strid med fredsplikten å aksjonere mot utøvelse av styringsrett hos en arbeidsgiver som er bundet av reelt sett samme tariffavtale som de aksjonerendes arbeidsgiver, men som ikke er innenfor samme tarifforhold. I privat sektor inngås ofte tariffavtaler direkte mellom en enkelt arbeidsgiver og en fagforening. I slike situasjoner gjør argumentet om at fredsplikt består mellom tariffpartene seg ikke tilsvarende gjeldende. Heller ikke argumentet om at aksjonen i realiteten vil rette seg mot egen tariffavtale, gjør seg gjeldende på samme måte som når arbeidsgiverne er innenfor samme tarifforhold. Det er således ikke like god grunn til at utøvelse av styringsrett hos 
andre arbeidsgivere i slike tilfeller skal være underlagt fredsplikt, som der arbeidsgiverne er innenfor samme tarifforhold.

Jeg har nå gjort rede for særlige grunnlag for identifikasjon mellom ulike arbeidsgivere. Identifikasjon kan imidlertid også tenkes av andre grunner enn de som er skissert foran. Denne problemstillingen har vært behandlet av Arbeidsretten to ganger. I én av sakene kom retten til at det var grunnlag for identifikasjon mellom beslutningstakeren og arbeidsgiverbedriften. Ettersom beslutningen etter sin art også kunne anses som utøvelse av styringsrett, var den underlagt fredsplikt.

Den første dommen hvor spørsmålet kom opp er ARD 1989 s. 134. Når det gjelder sakens faktum, viser jeg til avsnitt 6.2 foran, hvor det også fremgår at hovedbegrunnelsen for at beslutningen ikke kunne anses som utøvelse av styringsrett, var forhold ved beslutningens art. Arbeidsretten bemerket imidlertid også at bankforeningene ikke kunne «identifiseres med bankene som arbeidsgivere i relasjon til bankoverenskomsten» (s. 147). Synspunktet ble ikke nærmere begrunnet. Man er dermed overlatt til å resonnere på grunnlag av den faktiske tilknytningen mellom bankforeningene og arbeidsgiverne. De to bankforeningene som tok beslutningen, var Den norske Bankforening (Bankforeningen) og Sparebankforeningen i Norge (Sparebankforeningen). Begge foreningene var interesseorganisasjoner for banknæringen og hadde en rekke banker som medlemmer. En interesseorganisasjon har typisk et annet nedslagsfelt enn en arbeidsgiverorganisasjon. Mens en arbeidsgiverorganisasjon har som primær oppgave å fremme medlemmenes interesser som arbeidsgivere, er interesseorganisasjoners oppgave å ivareta bransjens interesse. Det vil derfor være mer nærliggende å anse beslutninger fra en arbeidsgiverorganisasjon som utøvelse av styringsrett, enn det som vil være tilfelle for en interesseorganisasjon. Noe klart skille mellom disse to organisasjonsformene er det likevel ikke. For eksempel er NHO både en interesseorganisasjon og en arbeidsgiverforening. I ARD 1989 s. 134 var imidlertid dette skillet klart. Det var ingen tvil om at bankforeningene var interesseorganisasjoner, og at Bankenes Arbeidsgiverforening var den aktuelle arbeidsgiverforeningen. Et annet faktum som også trakk i retning av at det ikke var 
grunnlag for identifikasjon, var at kun halvparten av medlemmene i Bankforeningen også var medlem i Bankenes Arbeidsgiverforening. ${ }^{41}$

I ARD 2001 s. 243 kom retten derimot til at det var grunnlag for identifikasjon mellom arbeidsgiverbedriften og beslutningstakeren. Den sentrale problemstillingen for retten var om beslutningen til AS Oslo Sporveier om å selge sine aksjer i datterselskapet AS Sporveisbussene kunne anses som utøvelse av styringsrett overfor arbeidstakerne i Sporveisbussene. $^{42}$ Spørsmålet om det var grunnlag for identifikasjon mellom Oslo Sporveier og Sporveisbussene, ble avgjort på grunnlag av den selskapsrettslige tilknytningen mellom selskapene. Retten viste i denne sammenheng til at Sporveisbussene var et «heleiet datterselskap», som tidligere var «skilt ut fra morselskapet» (s. 257). Det var følgelig ikke alene tilstrekkelig for identifikasjon, at beslutningstakeren var morselskapet til arbeidsgiverbedriften. Dommen kan derfor ikke regnes som noe «prejudikat» for at det ikke er adgang til å gå til demonstrasjonsaksjon mot en beslutning i arbeidsgiverbedriftens morselskap. Dette har også støtte i rettens bemerkning om at det ikke var nødvendig å gå inn på det generelle spørsmålet om det etter fredspliktnormene var adgang til å iverksette demonstrasjonsaksjon rettet mot noen med eierinteresser i arbeidsgiverbedriften (s. 257).

ARD 2001 s. 243 er det eneste eksempelet på at en beslutning av andre enn arbeidsgivere innenfor de aksjonerendes tarifforhold har blitt ansett som omfattet av fredsplikt. Dommen representerer dermed en utvikling av eldre rettspraksis. Begrunnelsen i 2001-dommen er imidlertid svært konkret og gir liten veiledning for andre saker. Arbeidsretten har kun ved ett annet tilfelle tatt stilling til spørsmålet om identifikasjon - i ARD 1989 s. 134. Der var situasjonen en helt annen enn i ARD 2001 s. 243, og det er derfor vanskelig å trekke noe ut av dommene samlet sett.

41 Se dommens gjengivelse av faktum, hvor det fremgikk at bare halvparten av medlemmene i Bankforeningen også var medlem av Bankenes Arbeidsgiverforening (s. 135). I Sparebankforeningen var imidlertid alle dens medlemmer også medlem i Bankenes Arbeidsgiverforening.

42 Dommen gir også veiledning for vurderingen av om en beslutning etter sin art kan anses som utøvelse av styringsrett. Om denne delen av dommen og om faktum for $\emptyset$ vrig viser jeg til avsnitt 6.2 foran. 


\subsection{Sammenfatning}

Fra og med 1989 har Arbeidsretten vurdert en påstått politisk aksjons forhold til utøvelse av styringsrett i åtte saker. Bare i to av dommene, i ARD 1989 s. 134 og i ARD 2001 s. 88, kom retten til at den aktuelle beslutningen ikke kunne anses som utøvelse av styringsrett i relasjon til fredsplikten. I begge disse tilfellene var det en annen enn den formelle arbeidsgiveren som hadde tatt den aktuelle beslutningen. I ARD 1989 s. 134 var begrunnelsen for at beslutningen ikke var underlagt fredsplikt at den etter sin art ikke kunne anses som utøvelse av styringsrett, og at den var tatt av en annen enn den aksjonerende parts arbeidsgiver. Arbeidsrettens praksis gir imidlertid ett eksempel på at en beslutning fra andre enn de aksjonerendes arbeidsgiver ble ansett underlagt fredsplikt: ARD 2001 s. 243. Denne dommen representerer en utvikling av eldre rettspraksis. Også ARD 2001 s. 88 har bidratt til en klargjøring av gjeldende rett, når det gjelder den nærmere grensedragningen mellom utøvelse av kompetanse på rent politisk grunnlag og utøvelse av styringsrett. Det sentrale momentet ved denne vurderingen vil være hvilke hensyn som ligger til grunn for den konkrete beslutningen. 


\section{Interessetvister}

\subsection{Innledning}

Dersom det foreligger uenighet om noe som hevdes å være regulert i tariffavtalen, foreligger det en rettstvist, jf kapittel 5. I dette kapittelet er temaet derimot hva som er omfattet av fredsplikten i interessetvister. Kort sagt vil dette være oppfatninger om hva som skal høre med til en fremtidig regulering, jf arbtvl $\S 1$ bokstav j og tjtvl $§ 20 \mathrm{nr}$. 2. Som jeg har vært inne på tidligere, er fredsplikten i slike tvister relativ. Det gjelder både i sak og i tid. Om arbeidskamp i anledning en interessetvist er rettmessig, vil derfor både bero på det kravet interessetvisten angår, og på når kravet fremsettes. Når det gjelder relativiteten i sak, går det et viktig skille mellom krav som innebærer en endring av det som er tariffregulert, og krav om en ny regulering. Med krav som angår en ny regulering, sikter jeg til to ulike situasjoner. For det første til tilfeller der kravet ikke kan anses regulert i en bestående tariffavtale. For det andre til tilfeller der det ikke foreligger noen tariffavtale mellom partene fra før av, og det fremsettes krav om en tariffavtale. Hvilken av de to formene for interessetvister man har å gjøre med, «endring» eller «ny regulering», får direkte betydning for fredspliktens rekkevidde i tid. Før jeg går nærmere inn på spørsmålene om hva som skal til for at man har å gjøre med hver av disse to formene for interessetvister, vil jeg si noe om relativiteten i tid. Dette er viktig fordi tidspunktet for iverksettelse av kamptiltak, får betydning for spørsmålet om når det blir aktuelt å trekke grensen mellom politiske aksjoner og lovlig arbeidskamp i interessetvister, og fordi tidsaspektet kan få direkte betydning for selve grensedragningen. Dette kommer jeg tilbake til senere.

Dersom partene befinner seg $\mathrm{i}$ en tariffperiode, gjelder det et absolutt forbud mot arbeidskamp i interessetvister som angår krav som er regulert i tariffavtalen. Men dersom det ikke gjelder noen tariffavtale mellom partene, eller dersom tariffavtalen ikke regulerer det kravet som fremsettes, stiller det seg annerledes. I slike tilfeller vil det være adgang til kamphandlinger dersom man følger prosedyrene for plassoppsigelse og megling i 
arbeidstvistlovene. $^{43}$ Etter at den lovbestemte meglingen er gjennomført og oppsigelsesfristene er løpt ut, er det da full adgang til arbeidskamp i tvisten. Også i tvister som innebærer en endring av en tariffavtale, kan det være adgang til arbeidskamp. Forutsetningen er at avtalens gyldighetstid er løpt ut. ${ }^{44}$ I tillegg må den ettervirkningsperioden som følger av arbtvl $\S 8$ annet ledd annet punktum jf tredje ledd og tjtvl $§ 20$ nr. 2 første ledd jf annet ledd, være løpt ut, på samme måte som jeg har pekt på ovenfor.

Gjennomføring av arbeidskamp i interessetvister kan ha to mulige utfall: Partene kan enten bli enige om inngåelse av en ny tariffavtale, eller det offentlige kan gripe inn gjennom et vedtak om tvungen lønnsnemnd. ${ }^{45}$ Dersom partene blir enige om en ny tariffavtale, vil det igjen inntre fredsplikt for det som er tariffregulert, i samsvar med det som er sagt foran om fredsplikt i tariffperioden. Men dersom partene ikke blir enige og det fattes vedtak om at tvisten skal behandles ved tvungen lønnsnemnd, oppstår spørsmålet om dette har noen virkninger for fredsplikten - i utgangspunktet befinner jo partene seg $\mathrm{i}$ en periode hvor adgangen til arbeidskamp står åpen. Det er ingen tvil om at dette spørsmålet må besvares bekreftende. For det første vil den tariffavtalen som gjaldt ved tvistens utbrudd, «våkne til live» igjen, med virkning også for den tariffmessige fredsplikt. ${ }^{46}$ Det vil følgelig inntre fredsplikt om det som var regulert $\mathrm{i}$ den tariffavtalen som besto ved tvistens utbrudd. ${ }^{47}$ For det andre, og dette er sentralt i denne sammenheng, vil det inntre en fredsplikt ut over det den aktuelle tariffavtalen gir grunnlag for. Sagt på en annen måte bygger ikke fredsplikten bare på tariffavtalen, men også på selve vedtaket om tvungen lønnsnemnd. Dette har sammenheng med at et vedtak om tvungen lønnsnemnd vil være kombinert med et forbud mot arbeidskamp i den aktuelle tvisten.

$43 \quad$ Arbtvl $§ 8$ annet ledd første punktum,jf $\S \S 18$ og 25 . Tjtvl $§ 20$ nr. 2 første ledd første punktum, jf $\S 17$ første og annet ledd.

44 Arbtvl $\S 8$ annet ledd annet punktum. Tjtvl $§ 20$ nr. 2 første ledd siste punktum.

45 Prinsipielt kan også frivillig lønnsnemnd tenkes, men i dag er det svært uvanlig at partene benytter seg av denne ordningen.

$46 \quad$ Evju 1984 s. 266.

47 Dette gjelder selvsagt kun i tilfeller hvor det bestod en tariffavtale ved fristens utbrudd. 
Det får altså stor betydning for fredspliktens rekkevidde i interessetvister, hvorvidt tvisten angår krav som er tariffregulerte eller ikke. I dette kapittelet vil jeg først drøfte spørsmålet om hva som skal til for at noe kan anses å være tariffregulert. Deretter vil jeg se nærmere på hva som skal til for at noe er underlagt fredsplikten i interessetvister, der interessetvistkravet ikke angår en endring i det regulerte.

\subsection{Forholdet til aktuell regulering}

Problemstillingen i dette avsnittet er hva som skal til for at noe er omfattet av fredsplikten i interessetvister fordi det anses å være regulert i tariffavtalen. Det beror på en tolkning av tariffavtalen. En tvist som uttrykkelig angår spørsmålet om hva som kan anses som tariffregulert, vil være en rettstvist. Poenget i denne sammenheng er at konklusjonen på spørsmålet om noe kan anses som tariffregulert, får direkte betydning for fredspliktens rekkevidde i interessetvister. Er realiteten at det fremsettes et krav som vil gripe inn i og innebære en endring av det som er regulert, vil kravet være omfattet av fredsplikten i interessetvister i tariffperioden. Ettersom det er realiteten som er avgjørende, jf kapittel 8, er det ikke nødvendig at den aksjonerende part uttrykkelig fremsetter et krav om en endring av tariffavtalen.

Først og fremst er det klart at det som er positivt regulert i tariffavtalen, omfattes. Har tariffavtalen eksempelvis uttrykkelige bestemmelser om lønnssatser, vil et krav om lønnsøkning i større grad enn det tariffavtalen gir grunnlag for, være omfattet av fredsplikt. Et godt eksempel fra eldre praksis er ARD 1987 s. 61. I denne saken hadde Oslo kommune planlagt å ansette personell til barnehager ved en prosedyre som arbeidstakersiden påsto at avvek fra gjeldende tariffavtale. Oslo Førskolelag, som var tilsluttet den aktuelle tariffavtalen gjennom sitt medlemskap i Norsk Faglærerlag, oppfordret deretter sine medlemmer til å gjennomføre en arbeidsnedleggelse. Arbeidstakersiden hevdet at arbeidsnedleggelsen var rettmessig som en politisk aksjon, men fikk ikke medhold i dette. Den viktigste begrunnelsen var at aksjonens hovedformål var å demonstrere mot påståtte 
rettsbrudd fra arbeidsgivers side, og således gjaldt rettstvistspørsmål. I tillegg ble det lagt vekt på at arbeidsnedleggelsen i realiteten tok sikte på å fremtvinge endringer i den bestående tariffavtalen, ved at det ble fremsatt krav om lønnsøkning, bedre permisjonsordninger og $\varnothing \mathrm{kt}$ grunnbemanning. Dette var forhold som var omfattet av fredsplikten i interessetvister i tariffperioden. Retten uttalte i denne sammenheng at «[d]e sentrale elementer i OFØs supplerende begrunnelse for streiken ..., gjelder således interessetvistspørsmål som utvilsomt er undergitt fredsplikt i tariffperioden» (s. 70).

Også senere rettspraksis viser at krav om endringer i det som er positivt regulert, er omfattet av fredsplikt. I ARD 1989 s. 134 ble det iverksatt en aksjon av Norsk Bankfunksjonærers Forbund som følge av at bankforeningene hadde vedtatt å legge ned Bankakademiet. ${ }^{48}$ Aksjonen var ikke forenlig med fredsplikten fordi den hadde for nær tilknytningen til tarifforhandlinger som forbundet ønsket å føre. Forhandlingene ville angå spørsmålet om hvilke endringer som burde gjøres i tariffavtalens positive bestemmelser som følge av avviklingsvedtaket. Om forbindelsen mellom den bestående tariffavtalen og forhandlingene om en fremtidig regulering uttalte retten:

«En avvikling av Bankakademiet ville ha direkte innvirkning på anvendelsen av bankoverenskomstens bestemmelser om rettigheter til og rettsvirkninger av utdannelse ved institusjonen. NBF har også selv under prosedyren fremholdt av en avvikling av Bankakademiet ville bety en vesentlig endret forutsetning for tariffavtalen. Om det ikke var ubetinget nødvendig, ville det ihvertfall være i høy grad aktuelt å revidere overenskomstens bestemmelser» (s. 148).

Dommen i ARD 1994 s. 272 er et annet eksempel. ${ }^{49}$ I denne saken hadde bussjåførene ved AS Trondheim Trafikkselskap gått til arbeidsnedleggelse som følge av at bedriften hadde vedtatt å melde seg ut av KS. Aksjonen ble påstått å være rettmessig som en politisk demonstrasjon, noe arbeidstakersiden ikke fikk medhold i. Arbeidsretten begrunnet dette

48 Se kapittel 6 avsnitt 6.2 for mer om sakens bakgrunn.

49 Dommen er også omtalt kort under kapittel 6 punkt 6.32. 
med at formålet var å demonstrere mot de tariffmessige sidene av utmeldelsesvedtaket og de konsekvenser utmeldelsen kunne få for arbeidstakernes lønns- og arbeidsvilkår. At det ble demonstrert mot endringer i det som var positivt regulert i den bestående tariffavtalen, fremgår av en meddelelse fra «streikekomiteen» til arbeidsgiver av 29. desember 1993. Der ble det ble stilt krav om at arbeidsgiver sto «ved sine løfter/avtaler fra 1985», og om at arbeidstakerne skulle ha samme lønns- og arbeidsvilkår som andre ansatte i Trondheim kommune (s. 276). Det fremgikk av tariffavtalen av 1985, som ble reforhandlet i 1991, at «[1]ønns- og arbeidsvilkår ved AS Trondheim Trafikkselskap skal bygge på de avtaler som gjelder arbeidstakerne i Trondheim kommune» (s. 272). Sagt på en annen måte ble det demonstrert mot virkninger for og mulige endringer i tariffregulerte forhold.

Disse dommene viser at det gjelder fredsplikt for de forhold som er positivt regulert $\mathrm{i}$ tariffavtalen. Praksis går imidlertid lenger med hensyn til hva som må anses å være tariffregulert. Det har lang tradisjon at tariffavtalen i alminnelighet anses å innebære en helhetlig regulering av forholdet mellom partene. Det innebærer også at forhold som ikke er positivt regulert i tariffavtalen, kan være omfattet av fredsplikt.

Begrunnelsen for at tariffavtalen kan anses som en helhetlig regulering, er de forutsetninger partene normalt anses å bygge på, om at det skal herske arbeidsfred i tariffperioden. Slike forutsetninger kan ha kommet til uttrykk på ulike måter. Et eksempel er ARD 1923 s. 78, hvor det ble det iverksatt en aksjon for å tvinge gjennom avskjedigelser av uorganiserte arbeidstakere. Arbeidsretten kom til at aksjonen var i strid med fredsplikten, fordi arbeidstakersiden under forhandlingene hadde henvendt seg til arbeidsgiversiden for å få arbeidsgiver til å forplikte seg tariffrettslig til å avskjedige uorganiserte arbeidstakere. Kravet førte ikke frem, og spørsmålet ble ansett å være omfattet av fredsplikt i tariffperioden. Arbeidsretten uttalte her at ingen av partene «kan reise ny kamp om krav som det ikke har lykkes å få anerkjent under tariff-forhandlingene» (s. 83). Prinsippet om helhetlig regulering rekker imidlertid lenger. Det kan også føre til at krav eller omstendigheter som ikke ble tatt opp under forhandlingene, anses for å være tariffregulerte. Det sentrale hensynet som begrunner dette, er at en part har hatt oppfordring til å kreve det 
aktuelle forholdet regulert, men har unnlatt å gjøre det. Den grunnleggende dommen på dette punkt er ARD 1922 s. 86. Grunnlaget for fredsplikten var en voldgiftsdom som hadde virkning som tariffavtale. I denne saken hadde arbeidstakersiden blokkert en bedrift for å tvinge gjennom gjeninnsettelse av en avskjediget arbeidstaker. Spørsmålet for Arbeidsretten var om dette var en del av arbeidsgivers utøvelse av styringsrett som var underlagt fredsplikt i tariffperioden. Arbeidsretten kom til at blokaden var urettmessig, fordi den hadde for nær tilknytning til et forhold som det var forutsatt at skulle være underlagt fredsplikt i tariffperioden. At dette var en forutsetning, ble begrunnet med at organisasjonen ikke tidligere hadde tatt opp spørsmålet om deres rett til å få delta i slike beslutninger, til tross for at det var klart at det ikke lå innenfor voldgiftsrettens mandat å ta stilling til dette spørsmålet, og til tross for at det kort tid etter voldgiftsdommen ble vedtatt en ny lov som regulerte spørsmålet (s. 88-89). Arbeidsretten bemerket at arbeidstakerne tidligere hadde hatt «adgang til å søke sitt krav om andel i bedriftsledelsen fremtvunget gjennem organisasjonsmessig kamp», og videre at når de unnlot å gjøre dette, var det fordi «der fra alle hold stiltiende blev forutsatt at man for den avgjørelse lovgivningen måtte treffe med hensyn til dette spørsmål» (s. 88).

Prinsippet om helhetlig regulering gjelder imidlertid ikke uten unntak. Ikke alle forhold som det kunne være naturlig å regulere i en tariffavtale, vil nødvendigvis anses for å være tariffregulerte. ARD 1981 s. 72 er et eksempel på dette. I forbindelse med at Viking Nordic Hotell ønsket å rasjonalisere arbeidet på kjøkkenet, ble det foreslått en ny ordning som innebar at kokkene skulle være ansvarlige for oppvasken ved kjøkkenet. For dette skulle kokkene motta en godtgjørelse på 300 kroner per måned. Kokkene nektet imidlertid å gå med på ordningen, og spørsmålet for Arbeidsretten var om nektelsen var i strid med fredsplikten. Arbeidsretten kom til at dette ikke var tilfelle. Retten drøftet først om arbeidet med oppvasken var basert på en tariffavtale mellom partene. Dette berodde på en tolkning av tariffavtalen. Arbeidsretten kom til at arbeidet med oppvasken ikke var uttrykkelig regulert i tariffavtalen, og at det heller ikke kunne anses å være indirekte regulert. Arbeidsretten uttalte i denne sammenheng at $\ll[\mathrm{h}]$ vis bedriften hadde ment at kjelevasken m.v. hørte med til kokkenes arbeidsområde etter tariffavtalen, og at kokkene gjennom 
styringsretten kunne tilpliktes å påta seg dette arebid, måtte den ha gjort dette klart under konferansene» (s. 83). Spørsmålet ble deretter om nektelsen av å utføre arbeidet likevel kunne være underlagt fredsplikten i interessetvister. Denne delen av dommen kommer jeg tilbake til i neste avsnitt. Et annet eksempel gir ARD 2001 s. 382. Forholdet var her at boreriggen «West Epsilon»skulle avslutte sitt arbeid på norsk sokkel, gå til verksted i Skottland og deretter flyttes til Nederland for å utføre et oppdrag der. I forbindelse med forhandlingene om hvilke arbeidsvilkår som skulle gjelde for arbeidet på britisk og nederlandsk sokkel, ble det varslet plassoppsigelse og gjennomført frivillig megling. Etter at meglingen ikke førte frem, gikk arbeidstakersiden til arbeidsnedleggelse. Streiken hadde som formål både å fremtvinge en tariffregulering av hvilke generelle arbeidsvilkår som skulle gjelde for arbeidet på britisk og nederlandsk sokkel og å tvinge frem en regulering om hvilke arbeidstakere som skulle gis rett til å følge med riggen. Spørsmålet for Arbeidsretten var om interessetvistkravene allerede var regulert i tariffavtaler mellom partene. Det var utvilsomt at kravene ikke var regulert i overenskomsten mellom partene (s. 402). Spørsmålet ble deretter om kravene kunne anses å være regulert i en protokoll mellom partene, som arbeidstakersiden hevdet at hadde virkning som en lokal tariffavtale. Før retten gikk over til den konkrete vurderingen av dette spørsmålet, kom de med flere generelle bemerkninger om fredspliktens relativitet i interessetvister:

«Fredspliktens kjerne er at den i tariffperioden innebærer en plikt for tariffavtalens parter og deres tariffbudne medlemmer til å avstå fra og å motvirke bruk av kampmidler som har som formål å påvirke disse medlemmenes egne, tariffordnende lønns- og arbeidsvilkår ... Det er på den annen side sikker rett at fredsplikten ikke er til hinder for arbeidskamp i tariffperioden dersom interessetvisten gjelder lønns- og arbeidsvilkår som ikke kan anses som direkte eller indirekte regulert $\mathrm{i}$ en bestående tariffavtale» (s. 402; kursivert i originalen).

Retten fant ikke grunn til å ta stilling til spørsmålet om protokollen kunne regnes som en lokal tariffavtale, da de uansett kom til at de forhold interessetvisten angikk, ikke var regulert i protokollen. Det var på det rene at forholdene ikke var positivt regulert i tariffavtalen. Når det gjaldt spørsmålet om de kunne anses å være indirekte regulert, uttalte 
Arbeidsretten: «Ut fra forklaringene må Arbeidsretten legge til grunn at partene under forhandlingene den 22. oktober kun tok sikte på å regulere disse forhold. Protokollen kan derfor ikke under noen omstendighet forstås slik at den tar sikte på en helhetlig regulering ...» (s. 404; kursivert i originalen).

Dersom et krav som fremmes ved en aksjon ikke anses å være regulert i bestående tariffavtale, er det et spørsmål om forholdet likevel kan være omfattet av fredsplikten i interessetvister. Hva som skal til for at dette er tilfelle, behandler jeg i neste avsnitt.

\subsection{Fremtidig regulering}

Jeg går nå over til å drøfte hva som skal til for at et forhold er omfattet av fredsplikten i interessetvister selv om det spørsmål interessetvisten angår, ikke er regulert i en tariffavtale mellom partene. I slike tilfeller er det klare utgangspunktet at adgangen til arbeidskamp står åpen. Dette utgangspunktet modifiseres av to forhold, jf avsnitt 7.1 foran. For det første av de generelle kravene til megling og plassoppsigelse, og for det andre dersom det vedtas at tvisten skal behandles ved tvungen lønnsnemnd. I utgangspunktet vil det derfor bare være i situasjoner hvor reglene om plassoppsigelse eller megling ikke er fulgt, eller hvor det er fattet vedtak om tvungen lønnsnemnd at det vil være aktuelt å trekke grensen mellom «politiske» formål og interessetvister om spørsmål som ikke er tariffregulerte. Selv om de to situasjonene har dette til felles, vil jeg ved den videre fremstilling skille mellom de to, først og fremst fordi fredspliktens rekkevidde i tilfeller hvor det er fattet vedtak om tvungen lønnsnemnd, reiser særlige spørsmål. Jeg vil først vurdere hva som skal til for at et spørsmål er underlagt fredsplikt fordi reglene om megling og plassoppsigelse ikke er fulgt.

Det er ingen tvil om at en oppfatning om innholdet av en fremtidig tariffavtale vil måtte avgrenses mot «politiske» formål. Det følger uttrykkelig av arbtvl $§ 1$ bokstav $\mathrm{j}$ at dette vil være en interessetvist, jf også tilsvarende bestemmelse i tjtvl $§ 20$ nr. 2 første ledd første

punktum. Situasjonen i ARD 1981 s. 72 er en illustrasjon av dette. Som det fremgår av avsnitt 7.2 foran, var spørsmålet om kokkenes nektelse av å påta seg ansvaret for 
oppvasken, var tariffstridig og ulovlig. Selv om Arbeidsretten kom til at arbeidet med oppvasken ikke var regulert i tariffavtalen mellom partene, ble det reist spørsmål om nektelsen av å utføre arbeidet likevel kunne være omfattet av fredsplikten i interessetvister. Arbeidsretten besvarte spørsmålet benektende under henvisning til at arbeidstakernes nektelse utelukkende var knyttet til «en særskilt arbeidsordning» som gjaldt ved siden av tariffavtalen (s. 83).

Arbeidsrettens oppfatning om at den kollektive nektelsen av å utføre arbeidet ikke var å anse som kamptiltak i en interessetvist, er noe vanskelig å forene med arbeidstvistlovens definisjoner av interessetvister og streik. Etter arbtvl $§ 1$ bokstav $\mathrm{j}$ vil en interessetvist være en tvist mellom en fagforening og en arbeidsgiver om den fremtidige ordningen av lønnsog arbeidsvilkår. ${ }^{50}$ Det er på det rene at arbeidstakernes kollektive opptreden i ARD 1981 s. 72, innebar at de måtte anses som en fagforening i arbeidstvistlovens forstand. Videre er det klart at spørsmålet om de i fremtiden var forpliktet til å utføre kjelevasken, var et spørsmål om den fremtidige ordningen av lønns- og arbeidsvilkår. Når arbeidstakerne da gikk til en delvis arbeidsnedleggelse for å oppnå at de ikke skulle være forpliktet til å utføre kjelevasken, kan jeg ikke se annet enn at det dreide seg om en streik i arbeidstvistlovens forstand.

Jeg har nå vist at en oppfatning om innholdet av en fremtidig tariffregulering må avgrenses mot det som kan gjøres til objekt for rettmessige politiske aksjoner. Et spørsmål som gjenstår er hvilken rekkevidde fredsplikten i interessetvister har i tilfeller hvor det er varslet eller fattet vedtak om at tvist mellom partene skal behandles ved tvungen lønnsnemnd. Arbeidsretten har i en lang rekke dommer lagt til grunn at det i slike tilfeller gjelder et grunnvilkår for politiske aksjoners rettmessighet. Dette har blitt formulert som at aksjonen må være «ubetinget utløst fra - og uavhengig av - et konkret lønnsoppgjør». ${ }^{51}$ Det nærmere

$50 \quad$ For enkelhetens skyld har viser jeg til arbeidstvistloven 2012, selv om det var arbeidstvistloven 1927 som ble anvendt i saken. Det er imidlertid klart at det ikke var meningen å gjøre realitetsendringer i arbeidstvistloven 1927 på dette punkt, jf Prop.134 L (2010-2011) s. 72-73.

51 Jf eksempelvis ARD 1970 s. 72 (s. 79). 
innholdet av grunnvilkåret kommer jeg nærmere tilbake til i neste kapittel, under avsnitt 8.5. 


\section{Formålskravet}

\subsection{Innledning}

Til nå har jeg drøftet hvilke typer av forhold som hører med til det tariffregulerte og som følgelig er omfattet av fredsplikt (kapittel 5-7). Spørsmålet i dette kapittelet er hvilken sammenheng mellom det tariffregulerte og aksjonen som er avgjørende ved vurderingen av om aksjonen er i strid med fredspliktens saklige side. Det er klart at det sentrale momentet i denne vurderingen er aksjonens formål.

Under enhver omstendighet er det klart at de(t) reelle formål er avgjørende rettslig sett. Dette har blant annet kommet til uttrykk i ARD 1928 s. 48, hvor det ble uttalt at det «[a]vgjørende må være streikens sanne karakter, og ikke hva den blir kalt. Det er realiteten det må komme an på, og ikke formen» (s. 54). Fra senere rettspraksis kan det vises til ARD 1987 s. 61, hvor det fremgår at «det reelle formål» var avgjørende (s. 70). Er realiteten at formålet knytter seg til en rettstvist, utøvelse av styringsrett eller en interessetvist, er det klare utgangspunktet at aksjonen ikke er rettmessig som en demonstrasjonsaksjon. Det første spørsmålet blir etter dette, hvordan man skal foreta vurderingen av hva som er aksjonens reelle formål. Det er på det rene at det er vanskelig å oppnå sikker kunnskap om hvilke(t) formål en aksjon har. Høgberg har uttrykt dette slik i relasjon til kontraktstolkning: «formålet fremstår aldri "i seg selv", men har snarere karakter av å være noe man slutter seg til fra andre momenter/data». ${ }^{52}$ Man blir derfor nødt til å ta utgangspunkt i objektivt konstaterbare omstendigheter. I rettspraksis er det en rekke momenter som blir tillagt vekt i vurderingen av hva det reelle formålet er. Dette behandler jeg i avsnitt 8.2. Formålsvurderingen kan lede frem til ulike konklusjoner. Man kan enten komme til at aksjonen kun har formål som vil være i strid med fredsplikten eller til at den kun har formål som er forenlige med fredsplikten. En annen mulighet er at man kommer til at aksjonen har et sammensatt formål. Hvilken betydning disse to ulike situasjonene har for

\footnotetext{
52 Høgberg 2006 s. 45.
} 
rettmessighetsvurderingen, behandler jeg i henholdsvis avsnitt 8.3 og avsnitt 8.4. Til slutt $\mathrm{i}$ dette kapittelet, i avsnitt 8.5, vil jeg gå nærmere inn på de særlige reglene som gjelder der det foreligger et inngrep i et aktuelt tariffoppgjør mellom partene, herunder der det er fattet vedtak om tvungen lønnsnemnd.

\subsection{Momenter som kan belyse det reelle formålet}

Problemstillingen her er hvordan man skal vurdere hva aksjonens reelle formål er. Selv om det er på det rene at det reelle formålet er avgjørende, er dette ikke til hinder for at den aksjonerende parts uttalelser i forbindelse med aksjonen kan ha betydning ved denne vurderingen. Slike uttalelser kan ha kommet til uttrykk på flere måter: gjennom brev og varsler til motparten, gjennom skriv fra foreningen til dens medlemmer, men også gjennom uttalelser utad, som for eksempel i mediene. ARD 1989 s. 165 kan belyse dette. Her måtte Arbeidsretten ta stillingen til rettmessigheten av en aksjon iverksatt av Norsk Sykepleierforbund (NSF). Arbeidsretten kom til at det var åpenbart at formålet var i strid med fredsplikten (s. 174). ${ }^{53}$ Ved den konkrete vurderingen ble det lagt vekt på at tiltakene etter den aksjonerende parts egne uttalelser var uttrykkelig rettet mot et styrevedtak ved Regionssykehuset i Troms $\emptyset$. Arbeidsretten bemerket at aksjonene var «utrykkelig rettet mot styrevedtaket, så vel i sentralstyrets vedtak 22. oktober som i de senere meddelelser om tiltakene» (s. 173). Retten gikk ikke nærmere inn på hvilke uttalelser i de ulike meddelelsene som viste at aksjonen var rettet mot vedtaket. Men det fremgikk av en av uttalelsene at et av tiltakene fra NSF side var «begrunnet med»styrevedtakene.

ARD 1994 s. 272 er et annet eksempel på det samme. Her viste retten til at det fremgikk av den aksjonerende parts " "krav", meddelelser og løpesedler at aksjonen rettet seg mot

53 Formålet var å demonstrere mot et ansettelsesvedtak ved Regionsykehuset i Troms $\emptyset$. Dette var et formål som ikke var forenlig med fredsplikten fordi det dels rettet seg mot en rettstvist, jf kapittel 5 avsnitt 5.2, dels fordi det rettet seg mot arbeidsgivers utøvelse av styringsrett jf kapittel 6 avsnitt 6.2. 
tariffregulerte forhold» (s. 281). ${ }^{54} \mathrm{I}$ varselet om den påståtte politiske aksjonen, av 29. desember 1993, ble det fremsatt krav mot arbeidsgiver om at arbeidstakerne skulle få beholde de daværende lønns- og arbeidsvilkår til tross for at arbeidsgiver hadde vedtatt å melde seg ut av KS.

Det finnes langt flere eksempler på at den aksjonerende parts uttalelser har blitt brukt som et argument for at aksjonens reelle formål var å ramme fredspliktbeskyttede omstendigheter. I ARD 1990 s. 180 ble det bemerket at aksjonen «fremtrådte også, etter det varsel som ble gitt og etter NHFs løpeseddel» som direkte rettet mot et styrevedtak i arbeidsgiverbedriften (s. 187). I ARD 1993 s. 147 ble det sett hen til uttalelser fra den aksjonerende part i foreningens halvårsvedtak, en pressemelding sendt ut i forkant av aksjonen og i en løpeseddel (s. 169).

Et annet forhold ved den aksjonerende parts uttalelser som kan ha betydning, er hvem som er gjort til adressat for uttalelsene. Dette er særlig aktuelt for forhåndsvarslet av den politiske aksjonen. I ARD $1982 \mathrm{~s} .150$ ble det lagt vekt på at de politiske myndigheter som aksjonen var hevdet å rette seg mot, ikke var gjort til adressater i varselbrevet (s. 166). Begrunnelsen for at dette momentet kan kaste lys over aksjonens formål, kan være at det er en presumsjon for at den aksjonerende part vil orientere den eller de som aksjonen har til formål å påvirke. Fra den aksjonerende parts ståsted vil det være viktig at denne eller disse vet om at det gjennomføres en aksjon. I motsatt fall vil det være liten sjanse for at aksjonens formål vil realiseres. En unnlatelse av å varsle til den aksjonen hevdes å rette seg mot, vil derfor tale mot at det reelle formålet var å ramme vedkommende. Derimot kan det ikke være grunnlag for å legge vekt på at det faktisk er varslet til tariffmotparten, slik at dette vil tale for at det reelle formålet er å ramme tariffmotparten. Ettersom det i dag kan være god grunn til å oppstille et vilkår om forhåndsvarsling av politiske aksjoner, jf kapittel 10, ville det være urimelig om et varsel i samsvar med dette, kunne vektlegges i den aksjonerende parts disfavør.

ARD 1982 s. 150 gjaldt en aksjon som ble gjennomført etter det var vedtatt at en interessetvist mellom partene skulle behandles med tvungen lønnsnemnd. Saken angikk følgelig en type situasjon

$54 \quad$ Se nærmere oppgavens kapittel 7, avsnitt 7.2. 
som jeg i hovedsak behandler i avsnitt 8.5. Likevel er det ingen grunn til at man ikke skal kunne vektlegge hvem som er gjort til adressat for forhåndsvarselet også i andre tilfeller. I denne sammenheng kan det også nevnes at det i stor grad er de samme faktiske momentene som får betydning ved vurderingen av aksjonens formål i de situasjoner som behandles i avsnitt 8.5 som her.

Et annet viktig moment i ARD 1982 s. 150 var tidspunktet for gjennomføringen av aksjonen. Ved vurderingen av hva formålet med aksjonen var, bemerket retten at det var uklart hvordan en uttalelse fra den aksjonerende part skulle forstås (s. 165-166). Det ble deretter vist til at den aksjonerende part måtte ha risikoen for den uklarhet som forelå, og til det «spesielle aktsomhetskrav som må stilles til partene når de står oppe i en tarifftvist» (s. 166). Det er nærliggende å forstå uttrykket «tarifftvist» som en henvisning til en interessetvist, jf Arbeidsrettens bemerkninger innledningsvis i dommen om tidligere rettspraksis (s. 164-165). Det kan derfor stilles spørsmål om uttalelsen ikke er anvendelig på situasjoner hvor partene ikke befinner seg i en interessetvist. Svaret på dette spørsmålet blir imidlertid ikke avgjørende for om tidspunktet for gjennomføringen av aksjonen kan kaste lys over aksjonens reelle formål. Også i ARD 1985 s. 40 ble det sett hen til tidspunktet for gjennomføringen av aksjonene, nærmere bestemt at dette var sammenfallende med gjennomføringen av en beslutning $\mathrm{i}$ arbeidsgiverbedriften. Den nærmere bakgrunn for saken var et stortingsvedtak om bevilgninger til A/S Sydvaranger. Vedtaket bygget på at det skulle gjennomføres et endret driftsopplegg i bedriften. Som følge av dette fattet styret i Sydvaranger et vedtak som påla administrasjonen å gjennomføre et endret driftsopplegg. Den 2. mai 1985 kl. 10 ble det holdt møte mellom bedriften og foreningene, hvor bedriften informerte om at det endrede driftsopplegget ville bli innført fra kl. 14 samme dag. Det ble deretter klart at foreningen kom til å iverksette en tidligere varslet politisk streik samme dag fra det tidspunktet det endrede driftsopplegget ble iverksatt. Arbeidstakersiden anførte at aksjon var rettet mot Stortinget og Regjeringen i anledning stortingsvedtaket av 30. mars 1985. Men Arbeidsretten kom til at aksjonen fremtrådte som rettet mot styrevedtaket i A/S Sydvaranger og administrasjonens oppfølging av det. En viktig del av rettens begrunnelse var at aksjonen først ble iverksatt etter at det $\mathrm{i}$ bedriftens styre ble truffet vedtak om endret driftsopplegg og etter at 
administrasjonen fors $\varnothing$ kte å gjennomføre vedtaket. Det ble i denne sammenheng uttalt at «[s]elv om det endrede driftsopplegg må ses som en konsekvens at stortingsvedtaket, er aksjonen således konkretisert i forhold til bedriftens driftsplan og gjennomføringen av den» (s. 49).

Et annet eksempel på at aksjonens tidspunkt ble brukt til å belyse aksjonsformålet, finnes i ARD 2001 s. 243. Arbeidstakersiden anførte at aksjonen, som ble gjennomført 6. juli 2000, var rettmessig som en politisk aksjon, fordi det primære formålet var å demonstrere mot Oslo kommunes bevilgningspolitikk. ${ }^{55}$ Arbeidsretten kom derimot til at hovedformålet var å demonstrere mot det forestående vedtaket i Oslo Sporveiers styre. Tidspunktet for varslingen og gjennomføringen av arbeidsnedleggelsen var viktige momenter i denne vurderingen. Her ble det for det første sett hen til at det ikke pågikk noen sak i de politiske beslutningsorganene i Oslo kommune det første halvåret i år 2000 (s. 256). For det andre ble det lagt vekt på at det forelå en tidsmessig sammenheng mellom aksjonen og behandlingen av saken i Oslo Sporveiers styre. Det ble her uttalt at «behandlingen av spørsmålet om eventuelt salg av aksjer i AS Sporveisbussene gjensto som et nødvendig ledd i den videre saksgang», og videre bemerket at valg av tidspunkt for gjennomføring av aksjonen hadde nær sammenheng med at det var planlagt et styremøte i Oslo Sporveier i nærmeste fremtid (s. 256).

I ARD 2001 s. 243 ble tidspunktet for gjennomføringen av aksjonen også ansett for å kaste lys over tilstedeværelsen av et annet viktig moment $\mathrm{i}$ vurderingen av aksjonens reelle formål: at aksjonen er egnet til å $\phi v e$ press på forhold som er underlagt fredsplikt. Arbeidsretten bemerket at «aksjonen utvilsomt [var] egnet til å øve press mot styrets og de enkelte styremedlemmenes standpunkttagen under den videre behandlingen av saken» (s. 256). Momentet om at aksjonen er egnet til å $\emptyset v e$ press i tvister som er omfattet av fredsplikt, inngår i en gruppe momenter hvor det sentrale er hvilke virkninger aksjoner har. Slike virkninger som behandles her, må skilles fra den type virkninger som behandles i kapittel 11. I avsnittet her er det først og fremst virkninger på fredspliktbeskyttede forhold

55 Om sakens bakgrunn for $\varnothing v$ vrig vises det til kapittel 6 avsnitt 6.2 . 
som er aktuelle. I kapittel 11 er det aksjonens øvrige negative konsekvenser for tariffmotparten som behandles, typisk at denne påføres et tap ved aksjonen.

Sondringen mellom de to ulike formene for virkninger kan by på tvil. Dette gjelder særlig skillet mellom aksjonens virkninger på utøvelse av styringsrett, og det at aksjonen fører til et økonomisk tap for arbeidsgiver. Grunnen til at arbeidsgiver påføres et økonomisk tap ved aksjonen, er jo at han hindres fra å disponere over sine ansatte i arbeidstiden. Etter min mening kan det imidlertid trekkes et skille mellom virkninger på en konkret beslutning som faller innenfor arbeidsgivers utøvelse av styringsrett, og at aksjonen har som følge av arbeidsgiver hindres fra å disponere over sine ansatte, slik at førstnevnte i større grad er egnet til belyse aksjonens formål enn sistnevnte. Grunnen til dette er at det nettopp er typisk for politiske aksjoner at de griper inn i arbeidsgivers rett til å disponere over de ansatte i arbeidstiden.

Et annet tilfelle fra rettspraksis hvor aksjonens virkninger på fredspliktbeskyttede forhold ble tillagt betydning ved formålsvurderingen, er ARD 1993 s. 147. Her viste retten til at aksjonen skilte mellom arbeidstakere som hadde den lokale avtalen tvisten stod om, og de som ikke hadde den. De som hadde avtalen ble unntatt fra aksjonen etter en time, i motsetning til de som ikke hadde avtalen. Retten uttalte $\mathrm{i}$ denne sammenheng at det $\mathrm{i}$ dette «lå et press mot den enkelte bedrift» (s. 169). Praksis viser imidlertid at det ikke bare har betydning hvilke virkninger aksjonen faktisk har, men også hvilke virkninger aksjonen ikke er egnet til å ha. I ARD 1989 s. 47 hadde arbeidstakersiden anført at aksjonen rettet seg mot myndighetens holdning til den sikkerhetsmessige risiko en reduksjon av bemanningen $\mathrm{i}$ radiorommet ville føre til. Arbeidsretten kom imidlertid til at det dominerende formålet var å fremtvinge en annen løsning for arbeidsgiverbedriftens vedkommende enn det bedriften selv hadde bestemt seg for. Et viktig moment ved denne vurderingen var at aksjonen ikke var egnet til å få myndighetene til å endre sitt standpunkt. Det ble her bemerket at «[d]et må forsåvidt være klart at en demonstrasjonsaksjon for å få myndighetene til å innta et annet generelt standpunkt, slik OFS har hevdet at formålet her er, ikke er egnet til å nå sitt formål» (s. 57). 
Et siste moment jeg vil trekke frem, er aksjonens varighet. I ARD 1987 s. 61 ble en aksjon blant førskolelærerne i Oslo kjent tariffstridig og ulovlig. Arbeidsretten kom til at formålet dels knyttet seg til rettstvistspørsmål og dels til interessetvistspørsmål. ${ }^{56}$ Til støtte for at dette var formålene, ble det lagt vekt på aksjonens varighet, både på at aksjonen ikke var tidsavgrenset og på varigheten isolert sett. På domstidspunktet hadde aksjonen vart i to uker. Det ble i denne sammenheng uttalt at «streikens varighet så langt, og det forhold at OFØ i sitt varsel av 2. september uttrykkelig har meddelt at streiken ikke er tidsavgrenset, bidrar ytterligere til å underbygge at det reelle formål her ikke er en politisk demonstrasjonsstreik som ellers ville kunne anses ikke tariffstridig» (s. 70). Jeg har ikke funnet noe eksempel fra rettspraksis etter ARD 1987 s. 61 på at varigheten har vært tillagt betydning ved vurderingen av hva aksjonens formål er. Derimot har det skjedd en utvikling i retning av å godta varigheten som et selvstendig rettmessighetsvilkår. Dette behandles nærmere i kapittel 10. Men allerede her kan det stilles spørsmål om dette innebærer at gjeldende rett kun gir grunnlag for å anse varigheten som et selvstendig rettmessighetsvilkår. Et faktum som kunne trekke i en slik retning, er at Arbeidsretten i tre dommer avsagt etter ARD 1987 s. 61, unnlot å trekke inn varigheten som et moment ved vurderingen av aksjonens formål: i ARD 1989s.47, ARD 1990 s. 180 og ARD 1993 s. 147. Dette til tross for at alle aksjonene hadde en varighet ut over det som er vanlig for rettmessige politiske aksjoner. I 1989-dommen var det varslet at aksjonen skulle vare i 24 timer, i 1990-dommen varte arbeidsnedleggelsen i syv timer, mens i 1993dommen hadde aksjonen en varighet på to dager. Jeg kan heller ikke se at det var mindre tvil om hva formålet var i de tre siste dommene enn i ARD 1987 s. 61. Uansett kan disse betraktningene ikke være avgjørende. Det er karakteristisk for rettslige bevisvurderinger at de i stor grad er preget av skjønn, og det er derfor liten grunn til å oppstille bestemte krav om hva det vil være legitimt å legge vekt på ved slike vurderinger. Dette tilsier etter min mening at man ikke bør avskjære muligheten for å vektlegge aksjonens varighet ved vurderingen av hva det reelle formålet med aksjonen er.

$56 \quad$ Jf kapittel 7 avsnitt 7.2 . 
Som jeg var inne på innledningsvis, i avsnitt 8.1, kan man etter vurderingen av hva formålet er, komme til at aksjonen kun har en type formål, eller til at aksjonen har et sammensatt formål. I de to neste avsnittene, 8.3-8.4, vil jeg drøfte hvilken betydning disse to ulike situasjonene vil ha for rettmessighetsvurderingen.

\subsection{Aksjonen har en type formål}

Med aksjoner som har «en type formål»sikter jeg til aksjoner hvor de eneste formålene med aksjonen er å ramme fredspliktbeskyttede forhold eller hvor de eneste formålene er å ramme omstendigheter som faller utenfor fredsplikten. Jeg skiller følgelig ikke mellom aksjoner som har flere biformål som alle vil være i strid med fredsplikten, og aksjoner hvor det eneste formålet er i strid med fredsplikten. Det samme gjelder situasjoner der aksjonen har flere biformål som alle er forenlige med fredsplikten, og aksjoner hvis eneste formål er forenlig med fredsplikten. Aksjoner som kun har til formål å demonstrere oppfatninger om forhold som faller innenfor fredspliktens rammer etter kapittel 5-7, vil ikke godtas som rettmessige politiske aksjoner. Motsatt vil en aksjon som bare har til formål å demonstrere oppfatninger om spørsmål som faller utenfor fredspliktens rammer, godtas som en rettmessig politisk aksjon.

Et eksempel fra senere rettspraksis på at det ble avgjørende at det eneste formålet rettet seg mot fredspliktbeskyttede forhold, finnes i ARD 1989 s. $165{ }^{57}$ Arbeidsretten bemerket at «[m]ed det formål tiltakene her har, er det også klart at de var ... tariffstridige» (s. 175; min kursivering). Også i ARD 1994 s. 272 ble det eneste formålet avgjørende for bedømmelsen av aksjonens berettigelse. Formålet med aksjonen var å demonstrere mot de tariffmessige virkningene av at arbeidsgiver hadde vedtatt å melde seg ut av KS. Retten uttalte i denne sammenheng at «streiken rettet seg mot de tariffmessige sider at utmeldelsesvedtaket og dets virkninger for reguleringen av egne lønns- og arbeidsvilkår. Med det formål den

$57 \quad$ Jf kapittel 5 avsnitt 5.2 og kapittel 6 avsnitt 6.2 . 
således hadde, er det ikke tvilsomt at streiken var i klar strid med den tariffavtalebaserte fredsplikt» (s. 281; min kursivering).

Disse to dommene viser at dersom aksjonens eneste formål er å demonstrere mot forhold som er omfattet av fredsplikten, er aksjonen ikke rettmessig som en politisk aksjon. ARD 1993 s. 147 og ARD 1997 s. 193 viser at det samme vil gjelder dersom aksjonen har flere biformål som alle retter seg mot fredspliktbeskyttede forhold. I ARD 1993 s. 147 hadde aksjonen tre formål som alle var i strid med fredsplikten: aksjonen var rettet mot NHOs og bransjeorganisasjonenes syn på anvendelsen av avtaleverket, det var en hensikt å få NHO til å endre sin «politikk», og aksjonen var en reaksjon mot et påstått tariffbrudd ved en av bedriftene. Det var «utvilsomt» at aksjonen var i strid med fredsplikten (s. 170). I ARD 1997 s. 193 ble det avgjørende at aksjonen hadde to formål som var i strid med fredsplikten, jf rettens bemerkning om at «[b]egge deler er spørsmål som utvilsomt er undergitt fredsplikt ...» (s. 200).

Det er imidlertid også klart at dersom aksjonens formål kun retter seg mot forhold som ikke er omfattet av fredsplikt, vil aksjonen være forenlig med fredspliktens saklige side. ARD 1979 s. 37 er et eksempel på dette. Her var aksjonens eneste formål å demonstrere mot at arbeidsgiver bevilget penger til et politisk parti. Da dette ikke var en omstendighet som falt innenfor fredspliktens rammer ${ }^{58}$ ble aksjonen godtatt som en rettmessig demonstrasjonsaksjon. Arbeidsretten bemerket at aksjonen var «eksklusivt rettet mot eventuelle beslutninger fra bedrifters side om å bevilge penger til politiske partier» (s. 42; min kursivering). Fra nyere rettspraksis kan det her vises til ARD 2001 s. 88, hvor Arbeidsretten kom til at det eneste formålet var å demonstrere mot Stortingets og Regjeringens behandling av en stortingsproposisjon om eierskap i Statoil og fremtidig forvaltningen av SDØE. ${ }^{59}$ Retten uttalte at «det formål som forfølges ved den varslede streiken, isolert sett er forenlig med de alminnelige normer om fredspliktens rekkevidde»

\footnotetext{
$58 \quad$ Jf kapittel 6 avsnitt 6.2 .

59 Statens direkte $\varnothing$ konomiske engasjement.
} 
(s. 104). ${ }^{60}$ Ettersom retten kom til at formålet dels var å demonstrere mot Stortingets behandling og dels å demonstrere mot Olje- og energidepartementets forslag, illustrerer dommen at aksjoner som har flere formål som alle er forenlige med fredsplikten, vil bedømmes på samme måte som aksjoner som bare har ett eneste formål som er forenlig med fredsplikten.

Dersom man kommer til at aksjonens formål både knytter seg til omstendigheter som er omfattet av fredsplikt og til omstendigheter som faller utenfor fredsplikten, blir spørsmålet hva som i slike tilfeller blir avgjørende for vurderingen av en aksjons berettigelse.

\subsection{Aksjonen har et sammensatt formål}

Problemstillingen i dette avsnittet er hvordan man bedømmer en aksjons berettigelse der formålet dels knytter seg til forhold som er omfattet av fredsplikten, og dels knytter seg til forhold som faller utenfor fredspliktens rammer. I slike tilfeller er utgangspunktet at hovedformålet blir avgjørende. Før man kommer så langt, reiser det seg spørsmål om hva som skal til for at noe kan anses som aksjonens hovedformål. Her er det vanskelig å si noe generelt. Arbeidsrettens vurderinger på dette punkt er svært konkrete og gir i liten grad grunnlag for generelle slutninger. For at noe skal kunne være hovedformålet, er det imidlertid nærliggende å anta at dette noe må ha vært den viktigste begrunnelsen for å gjennomføre aksjonen. Dersom man legger dette til grunn, blir spørsmålet hva som var det viktigste - å demonstrere en oppfatning om forhold som er omfattet av fredsplikt, eller å demonstrere en oppfatning om omstendigheter som faller utenfor fredspliktens rammer. Ved den konkrete vurderingen av hva som var den viktigste begrunnelsen for gjennomføringen av aksjonen, er det sentralt hvilke enkeltformål eller biformål aksjonen kan sies å ha. Dette vil fremgå av den videre drøftelsen.

60 Slev om aksjonen ikke var i strid med fredspliktens saklige side, ble den kjent urettmessig fordi det ikke forelå forholdsmessighet mellom aksjonens varighet og virkninger. Denne delen av dommen behandler jeg i kapittel 11. 
At hovedformålet kan bli avgjørende for vurderingen av en aksjons rettmessighet, ble uttrykkelig lagt til grunn i ARD 1960 s. 1. Der uttalte Arbeidsretten blant annet: «Det er endelig ingen tvil om at ønsket om å demonstrere en politisk oppfatning ubetinget må være streikens hovedformål» (s. 8). Det følger uttrykkelig av denne uttalelsen at dersom hovedformålet er å demonstrere noe annet enn en politisk oppfatning, vil aksjonen ikke godtas som en rettmessig politisk aksjon. Et eksempel fra nyere rettspraksis er ARD 1989 s. 47. Som jeg tidligere har vært inn på, var sakens bakgrunn at Philips hadde besluttet å redusere bemanningen $\mathrm{i}$ radiorommet, og at Oljearbeidernes Fellessammenslutning varslet en arbeidsnedleggelse. Arbeidsretten kom til at det dominerende formålet var å demonstrere mot den aktuelle beslutningen i Philips. Denne beslutningen var en del av arbeidsgivers utøvelse av styringsrett. Det var dermed ingen tvil om at aksjonen var urettmessig. Arbeidsretten bemerket her at «[n]år dette er hovedformålet, vil streiken være tariffstridig etter de alminnelige tariffrettslige normer, og dessuten i strid med arbeidstvistlovens $§ 6$ nr. 1» (s. 57). Også i ARD 1990 s. 180 ble det avgjørende at aksjonens hovedformål var å demonstrere mot en beslutning som falt innenfor arbeidsgivers styringsrett. Saken gjaldt en aksjon iverksatt av Norsk Hjelpepleierforbund. Forbundet hadde anført at arbeidsnedleggelsen var rettmessig som en politisk demonstrasjon rettet mot «sentrale og fylkeskommunale politiske myndigheters manglende vedtak» $\mathrm{i}$ en sak som angikk videreutdanning av hjelpepleiere. Arbeidsretten kom imidlertid til at hovedformålet med aksjonen var å demonstrere mot et styrevedtak i et sykehus om hjelpepleieres plass i operasjonsavdelingen. Dette var et spørsmål som hørte til arbeidsgivers styringsrett, og siden hovedformålet var å demonstrere mot det aktuelle vedtaket, var aksjonen i strid med fredsplikten (s. 187).

I disse to dommene konkluderte retten uttrykkelig med at hovedformålet var i strid med fredsplikten. Det finnes imidlertid også eksempler på at retten ikke uttrykkelig konkluderer med at hovedformålet er fredspliktsstridig og at aksjonen derfor er urettmessig, selv om det er dette som må antas å ligge grunn for bedømmelsen av aksjonen. ARD 1995 s. 34 er et eksempel på dette. Spørsmålet i saken var om en aksjon blant ansatte i Oslo Sporveier 
hadde for nær tilknytning til en beslutning i bedriftens styre om å inngå en intensjonsavtale med Swebus. ${ }^{61}$ Selv om det ikke uttrykkelig ble konkludert med at aksjonens hovedformål var i strid med fredsplikten, ligger det nær å anta at det var dette som var realiteten i Arbeidsrettens vurdering. Jeg viser først og fremst til at retten ved den konkrete vurderingen av aksjonens forhold til fredsplikten uttalte at utgangspunktet måtte tas $i$ aksjonens «hovedformål» slik det faktisk fremtrådte (s. 46). Deretter ble det sett hen til en rekke biformål med aksjonen, herunder at aksjonen var «utløst av» forhandlingene, at den fremtrådte som «en reaksjon mot» at det ikke var grepet inn overfor selskapets ledelse og med «sikte på» å påvirke den videre beslutningsprosess i selskapet (s. 46). Det ble også lagt vekt på at aksjonen fremtrådte som «en reaksjon» mot et påstått tariffbrudd (s. 47). Uttrykkene «reaksjon mot»og «utløst av»kan umiddelbart gi inntrykk av at det foreligger en form for automatikk mellom en hendelse og en virkning. Dette kan imidlertid ikke være tilfelle når det gjelder menneskelige reaksjoner. For at en aksjon kan regnes som utløst av eller som en reaksjon mot tariffregulerte forhold, er det en forutsetning at de tariffregulerte forholdene utgjorde en motivasjon for å gjennomføre aksjonen. Jeg kan derfor ikke se at det å legge vekt på at en aksjon er en reaksjon mot noe, i realiteten er noe annet enn å legge vekt på at det var et formål med aksjonen å demonstrere mot den aktuelle omstendighet. Tilstedeværelsen av de fire enkeltformålene i ARD 1995 s. 34 innebærer etter mitt syn at det er svært nærliggende å gå ut fra at de til sammen utgjorde aksjonens hovedformål. At dette også var avgjørende for retten, har for det første støtte i formuleringen av utgangspunktet for drøftelsen: aksjonens hovedformål slik det faktisk fremtrådte. Jeg viser også til at rettens uttalelse om at aksjonen «i første rekke [måtte] anses rettet mot» Oslo Sporveiers styre, også kan forstås som en henvisning til aksjonens hovedformål (s. 47).

Dommen i ARD 2001 s. 243 er i denne sammenheng sammenlignbar med ARD 1995 s. 34. Også i 2001-dommen uttalte retten innledningsvis at utgangspunktet måtte tas i «aksjonen og dens hovedformål slik det faktisk fremtrer» (s. 255). Etter en lang drøftelse, hvor ulike faktiske momenter ble trukket inn, konkluderte retten med at aksjonen «først og fremst fremtrer som ... rettet mot den fortsatte behandlingen av spørsmålet om aksjesalg i styret i

61 Om dommens faktum for $\varnothing v$ rig, se kapittel 6 avsnitt 6.2. 
AS Oslo Sporveier» (s. 256). Det er nærliggende å forstå uttrykket «rettet mot», slik det ble brukt her, som en henvisning til aksjonens formål. En grunn til dette er at utsagnet fremstår som en konklusjon på det retten innledningsvis betegnet som utgangspunktet for den etterfølgende drøftelse: «aksjonens hovedformål slik det faktisk fremtrer». Det ble også bemerket at partene var uenige om hva «formålet eller formålene» med aksjonen var. I tillegg var de ulike momentene som ble tillagt betydning i rettens vurdering, etter min mening, tilstrekkelige til å begrunne at aksjonens hovedformål måtte anses å være å ramme behandlingen av aksjesalget i selskapets styre.

Jeg har nå vist at dersom aksjonens hovedformål ikke er forenlig med fredsplikten, vil aksjonen være urettmessig. Det neste spørsmålet blir om det motsatte gjelder dersom hovedformålet $\mathrm{er}$ forenlig med fredsplikten - vil aksjonen da være berettiget som en politisk aksjon $?^{62}$ Dette følger ikke utrykkelig av den siterte uttalelsen fra ARD 1960 s. 1 om at ønsket om å demonstrere en politisk oppfatning ubetinget må være streiken hovedformål (s. 8). Uttalelsen gir kun direkte grunnlag for å kjenne en aksjon urettmessig på grunn av hovedformålet.

En dom fra eldre rettspraksis som kan gi veiledning for spørsmålet er ARD 1976 s. 23. Arbeidsretten kom her til at hovedformålet med aksjonen var forenlig med fredsplikten, og uttalte at «[s]treikens hovedformål må antas å ha vært en demonstrasjon overfor Oslo bystyrets holdning til helse- og sosialpolitikk» (s. 39). At hovedformålet var forenlig med fredsplikten utgjorde en svært viktig del av begrunnelsen for at aksjonen var rettmessig. Dommen tilsier derfor at en aksjon vil være rettmessig dersom dens hovedformål er å demonstrere mot spørsmål som faller utenfor fredspliktens rammer.

Etter den siterte uttalelsen om hovedformålet ble det bemerket at det ikke var anført at aksjonen hadde en slik tilknytning til et «pågående eller umiddelbart forestående tariffoppgjør» at man sto overfor en situasjon som i ARD 1970 s. 65, ARD 1970 s. 72, ARD 1975 s. 12 og ARD 1975 s. 105.

62 Jeg presiserer at det med dette ikke er meningen å ta stilling til om en aksjon kan blir urettmessig på grunn av slike omstendigheter som behandles i del III. 
I disse fire dommene var spørsmålet om aksjoner i forbindelse med offentlige inngrep i partenes tariffoppgjør, var rettmessige som politiske aksjoner. Uttalelsen er følgelig ikke relevant for slike situasjoner som jeg behandler her, jf skillet som ble trukket opp i avsnitt 8.1. Spørsmålet om hvordan man bedømmer aksjoners berettigelse når de har tilknytning til slike inngrep, drøfter jeg i avsnitt 8.4 .

Også i ARD 1976 s. 96 var det spørsmål om et budsjettforslag fra Oslo kommune kunne anses som utøvelse av styringsrett i relasjon til fredsplikten. Arbeidsretten kom til at aksjonen var rettmessig som en politisk aksjon. Retten bemerket at aksjonen «i alt vesentlig hadde karakteren av en politisk demonstrasjon»(s. 103). Selv om retten ikke uttrykkelig konkluderte med at hovedformålet var forenlig med fredsplikten, ligger det nær å anse uttalelsen om at aksjonen «i alt vesentlig» hadde karakter av en politisk aksjon, som et uttrykk for at dette var tilfelle.

Også i ARD 2001 s. 88 kom Arbeidsretten til at aksjonen var forenlig med fredspliktens saklige side. ${ }^{63}$ Arbeidsretten konkluderte med at det eneste formålet med aksjonen ikke var omfattet av fredsplikt, se nærmere avsnitt 8.3. Den viktigste begrunnelsen for at aksjonen var i samsvar med fredspliktens saklige side, ser imidlertid ut til å ha vært at aksjonens hovedformål var å demonstrere mot Stortingets behandling, og at dette spørsmålet ikke falt innenfor fredspliktens rammer. Retten brukte langt mer plass på å drøfte om Stortingets beslutning kunne anses som utøvelse av styringsrett, enn på å drøfte om dette var tilfelle for departementets vedtak. Videre presiserte retten at det ikke var «avgjørende for saken» at den varslede arbeidsnedleggelsen også var uttrykk for protest mot departementets beslutning. Den viktigste begrunnelsen for at aksjonen var i strid med fredsplikten, var etter mitt syn at hovedformålet var å demonstrere mot Stortingets beslutning.

De tre dommene som er gjennomgått her, innebærer etter min mening at en aksjon vil være forenlig med fredspliktens saklige side dersom hovedformålet er forenlig med fredsplikten.

63 Imidlertid ble aksjonen kjent urettmessig fordi det ikke forelå forholdsmessighet mellom aksjonens varslede varighet og dens virkninger, se kapittel 11. 
Jeg har ikke funnet noe eksempel på at en aksjon har blitt urettmessig på grunn av fredspliktens saklige side, til tross for at retten kom til at hovedformålet var legitimt. Imidlertid finnes det flere eksempler på at retten har kommet til at en opptreden er i strid med fredspliktens saklige side, uten at det har vært tatt stilling til hva hovedformålet med opptredenen var. Disse eksemplene knytter seg til situasjoner hvor aksjonen har forbindelse med inngrep $\mathrm{i}$ et tariffoppgjør mellom partene, og først og fremst til aksjoner som har tilknytning til vedtak om tvungen lønnsnemnd.

\subsection{Særlig om inngrep i et tariffoppgjør}

\subsection{Innledning}

Problemstillingen i dette avsnittet er hvilken rekkevidde fredsplikten har i situasjoner hvor det gripes inn i et tariffoppgjør mellom partene. Rettspraksis viser at det i slike tilfeller kan bli spørsmål om å skjerpe rettmessighetsvurderingen i forhold til behandlingen foran. Det primære anvendelsesområdet for en slik skjerpet rettmessighetsvurdering, er situasjoner hvor det er fattet vedtak om at en interessetvist mellom partene skal behandles ved tvungen lønnsnemnd. Rettspraksis har her lagt til grunn at det gjelder et grunnvilkår for politiske aksjoners rettmessighet. I ARD 1970 s. 65 ble dette uttrykt som følger: «grunnvilkåret for at slike streiker går klar av fredsplikten under enhver omstendighet er at de er ubetinget utløst - fra og uavhengig av - et pågående eller forestående lønnsoppgjør» (s. 70). Grunnvilkåret er imidlertid også gitt anvendelse for andre inngrep i et tariffoppgjør enn vedtak om tvungen lønnsnemnd. Dette kommer jeg tilbake til. Det første spørsmålet jeg vil behandle, er hvordan innholdet av grunnvilkåret skal forstås der det er klart at en interessetvist mellom partene skal behandles ved tvungen lønnsnemnd. 


\subsection{Situasjonen ved tvungen lønnsnemnd}

Et vedtak om tvungen lønnsnemnd vil ha to sentrale virkninger for fredsplikten, jf kapittel 7 avsnitt 7.1. For det første vil den tariffavtalen som gjaldt ved tvistens utbrudd igjen ta til å gjelde, også med virkning for den tariffmessige fredsplikt. ${ }^{64}$ For det andre vil det inntre en fredsplikt som materielt sett rekker lenger enn det tariffavtalen gir grunnlag for, fordi et vedtak om tvungen lønnsnemnd vil være kombinert med et forbud mot arbeidskamp i den pågående tvisten. Grunnvilkåret har i slike situasjoner blitt formulert på ulike måter. I ARD 1966 s. 62 ble det lagt til grunn at «tariffbundne arbeidstakere ikke, uten å krenke fredsplikten, i tariffperioden kan nytte arbeidsnedleggelse som middel til å søke å fremtvinge en bestemt løsning av et forestående tariffoppgjør» (s. 67). I ARD 1970 s. 65 ble det, som det også fremgår av forrige avsnitt, uttalt at en aksjon må være «ubetinget utløst - fra og uavhengig av - et pågående eller forestående tariffoppgjør» (s. 70). Denne formuleringen er lagt til grunn i en rekke dommer siden. ${ }^{65}$ Nok en formulering finnes i ARD 1988 s. 61, hvor retten bemerket at en aksjon vil være i strid med fredsplikten dersom den har «saklig sammenheng med og finner sted i tilknytning til et aktuelt tariffoppgjør» (s. 68-69). ${ }^{66}$ Selv om formuleringene er ulike, finner jeg ikke grunn til å gå ut fra at de i realiteten henviser til ulike skjønnstemaer.

Det generelle utgangspunktet rettspraksis bygger på, er at en aksjon vil være i strid med fredsplikten dersom den har tidsmessig og saklig sammenheng med et vedtak om at en tvist mellom partene skal behandles ved tvungen lønnsnemnd. Dette gjelder fremfor alt i situasjoner hvor aksjonen har som formål å påvirke behandlingen av tvisten i Rikslønnsnemnda. Dette ble lagt til grunn i ARD 1966 s. 62. Etter at det var fattet vedtak om tvungen lønnsnemnd, gikk arbeidstakersiden til en arbeidsnedleggelse som ble påstått å

64 Evju 1984 s. 266

65 Jf blant annet ARD 1970 s. 72 (s.79), ARD 1975 s. 12 (s. 17), ARD 1982 s. 150 (s. 164).

66 Dommen dreide seg ikke om en situasjon hvor det var fattet vedtak om tvungen lønnsnemnd. Men den siterte formuleringen av grunnvilkåret ble ikke knyttet konkret til dommens faktum. Den har heller preg av å være en generell formulering. 
være rettmessig som en politisk aksjon (s. 66). Selv om Arbeidsretten kom til at aksjonen dels hadde politiske motiver, kunne aksjonen ikke godtas som en demonstrasjonsaksjon. Det ble begrunnet med at det var et formål med aksjonen å øve press på Lønnsnemndas behandling av interessetvisten. Arbeidsretten uttalte at det var klart at aksjonen «tok sikte på å øve press på Lønnsnemnda under dens behandling av det tariffoppgjør som var overlatt den til avgjørelse»(s. 67). Oppfatningen om at det ikke vil være adgang til å demonstrere mot Rikslønnsnemndas behandling, er utvilsomt fulgt opp i senere rettspraksis. Et eksempel på dette er ARD 1994 s. 246. Her var det vedtatt at en interessetvist om revisjon av hovedtariffavtalen for politiet, skulle behandles ved tvungen lønnsnemnd. Samarbeidsorganisasjonen Norsk Politiforbund/ Lensmannsetatenes Landslag (SPL) vedtok deretter å gå til en politisk aksjon, ved at de oppfordret medlemmene til å avstå fra oppgaver som ikke var tjenesteplikter (s. 247). Arbeidsretten kom til at dette ikke kunne regnes som en rettmessig demonstrasjonsaksjon. Selv om aksjonen dels hadde som formål å demonstrere en politisk oppfatning om bruk av tvungen lønnsnemnd, var dette formålet direkte knyttet sammen med den aktuelle interessetvisten «for å få denne løst»slik SPL $\emptyset$ nsket (s. 257). ${ }^{67}$

Det følger av disse to dommene at det ikke vil være adgang til å demonstrere mot Rikslønnsnemndas behandling av en interessetvist mellom partene. I realiteten er ikke dette særlig annerledes enn at en oppfatning om innholdet av en fremtidig tariffavtale vil være omfattet av fredsplikt, jf kapittel 7 avsnitt 7.3. Det Rikslønnsnemnda skal behandle, er jo nettopp spørsmålet om hva innholdet av en fremtidig tariffavtale skal være. Rettspraksis viser imidlertid at det ikke bare er aksjoner mot Rikslønnsnemndas behandling, som vil rammes av grunnvilkåret. Det vil heller ikke være adgang til å demonstrere mot selve vedtaket om tvungen lønnsnemnd. Dette gjelder selv om en beslutning om tvungen lønnsnemnd i og for seg bygger på politiske hensyn. ARD 1970 s. 65 er her en viktig dom. Etter at det var fattet vedtak om tvungen lønnsnemnd gikk arbeidstakersiden til en «politisk demonstrasjonsstreik» mot «Regjeringens og Odeltingets/Lagtingets bruk av tvang» (s. 67).

67 Det ble også lagt vekt på at aksjonen var gjennomført som «reaksjon og press mot» tariffmotpartens standpunkt i den verserende interessetvisten (s. 257). 
Arbeidsretten kom til at aksjonen var rettet mot vedtaket om tvungen lønnsnemnd, og at aksjonen derfor indirekte kunne virke som et press på Lønnsnemnda (s. 71). Aksjonen var av disse grunner tariffstridig og ulovlig. Urettmessighet ble følgelig begrunnet med at aksjonen og dens formål indirekte kunne virke som et press på utfallet av interessetvisten mellom partene. Også i ARD 1975 s. 12 ble en aksjon som hadde til formål å demonstrere mot et vedtak om tvungen lønnsnemnd, funnet tariffstridig. At aksjonen var urettmessig ble imidlertid ikke uttrykkelig begrunnet med at aksjonen og dens formål kunne virke som et press på Lønnsnemnda, slik som var tilfelle i ARD 1970 s. 65. Det var tilstrekkelig at formålet var å demonstrere mot vedtaket om tvungen lønnsnemnd. Som begrunnelse ble det blant annet vist til ARD 1970 s. 65, og til at det der var lagt til grunn at en aksjon ville være i strid med fredsplikten dersom den ikke var «ubetinget utløst fra og uavhengig av et foreliggende vedtak om ... tvungen lønnsnemnd» (s. 17).

Det som er sagt til nå, innebærer ikke at det ubetinget vil være i strid med fredsplikten å gjennomføre aksjoner når det er bestemt at en interessetvist mellom partene skal behandles ved tvungen lønnsnemnd. Dette har kommet til uttrykk i ARD 1982 s. 150 hvor ble gjengitt fra ARD 1970 s. 65, og deretter uttalt følgende: «Dette er ikke slik å forstå at arbeidstakerne er avskåret fra å gjennomføre en politisk demonstrasjonsstreik så lenge de står oppe i en tarifftvist» (s. 164). ${ }^{68}$ En aksjon hvor ingen del av formålet har noen som helst tilknytning til et konkret vedtak om tvungen lønnsnemnd (eller til andre forhold som er omfattet av fredsplikten, jf kapittel 5-7 og de neste avsnittene) vil måtte godtas. Imidlertid vil det faktum at det pågår en interessetvist mellom partene kunne føre til at vurderingen av hva aksjonens reelle formål er, skjerpes overfor den aksjonerende part. Også dette kom klart til uttrykk i ARD 1982 s. 150. Her bemerket retten at det var uklart hvordan en uttalelse fra den aksjonerende part skulle forstås, og at arbeidstakersiden måtte «ta ansvaret for den uklarhet som her foreligger» (s. 166). Det ble deretter vist til «det spesielle aktsomhetskrav» som retten oppstilte innledningsvis i dommen. Her ble det uttalt

68 Jf også ARD 1988 s. 61 hvor det ble bemerket at «[d]et syn retten har lagt til grunn ovenfor, innebærer forøvrig ikke at enhver adgang til politisk demonstrasjonsaksjon er avskåret alene fordi tidspunktet for aksjonen faller i sammenheng med et tariffoppgjør» (s. 70). 
at «den omstendighet at de befinner seg i en slik tvist med arbeidsgiveren, gjør at det må stilles ekstra krav på varsomhet fra arbeidstakernes side for at det ikke skal bli kollisjon med fredsplikten» (s. 164).

\subsection{Andre inngrep i et tariffoppgjør}

Arbeidsrettens praksis viser også at rettmessighetsvurderingen kan skjerpes ved andre inngrep i tariffoppgjør enn tvungen lønnsnemnd. ARD 1991 s. 107 er et eksempel på dette fra nyere rettspraksis. Her ble det ansett tariffstridig å demonstrere mot krav som skulle behandles av særskilt nemnd etter tjtvl $\S 27$. Selv om behandlingen av tvisten i slike tilfeller vil være overlatt til andre enn partene selv, er det her ikke treffende å snakke om offentlig myndighetsutøvelse. For det første er det en av partene som bestemmer om tvisten skal bringes inn for slik nemnd, og for det andre er det primært opp til partene hvordan nemnda settes sammen. Likevel er situasjonen ikke så rent ulik den som foreligger der det er fattet vedtak om tvungen lønnsnemnd, ettersom det ikke vil være adgang til å gå til arbeidskamp mot interessetvister som kan behandles etter tjtvl $§ 27 .{ }^{69}$ En sentral forskjell fra tilfeller der det er fattet vedtak om tvungen lønnsnemnd, er imidlertid at et vedtak om tvungen lønnsnemnd normalt kommer etter det har vært gjennomført arbeidskamp mellom partene. Mens i slike tvister som kan behandles etter tjtvl § 27 gjelder det et absolutt forbud mot arbeidskamp, også før tvisten bringes inn for nemndbehandling.

Bakgrunnen for saken i ARD 1991 s. 107 var at det var ført særavtaleforhandlinger mellom lærerorganisasjonene og staten som følge av at det var vedtatt en økning i det maksimale elevtallet for klasser i den videregående skole. Forhandlingene ble brutt og tvisten ble brakt inn for særskilt nemnd etter tjtvl § 27. Norsk Faglærerlag sendte deretter ut et skriv til sine medlemmer med oppfordringer til «boikott»av klasser hvor det økte elevtallet var innført. Arbeidsretten kom til at disse aksjonene var i strid med fredsplikten. Det var på det rene at

${ }^{69}$ Jf tjtvl § 20 nr. 3 gjelder det et absolutt fredsplikt ved inngåelse av særavtaler. 
aksjonen var en reaksjon mot bruddet $\mathrm{i}$ forhandlingene, ${ }^{70} \mathrm{og}$ at bruddet $\mathrm{i}$ forhandlingene kom som følge av at lærerorganisasjonene ikke vant frem med sine krav (s. 121). Disse kravene svarte til de som nå skulle nemndbehandles. Arbeidsretten viste her til at «[k]ravene er fremmet $\mathrm{i}$ forhandlingene, og de er fortsatt aktuelle $\mathrm{i}$ den verserende interessetvisten som skal nemndbehandles» (s. 121). Aksjonen var derfor i strid med fredsplikten.

Et mer spesielt eksempel på at det ble ansett tariffstridig å demonstrere mot et inngrep i et tariffoppgjør, finnes i ARD 1988 s. 61. Her ble en aksjon som hadde til formål å ramme et offentlig vedtak av langt mer generell karakter enn vedtak om tvungen lønnsnemnd og nemndbehandlingen i 1991-dommen, bedømt tariffstridig og ulovlig. Den 11. mars 1988 iverksatte YS en aksjon mot vedtakelsen av en ny inntektsreguleringslov. Det ble ved loven tatt sikte på å regulere inntektsoppgjørene i 1988. Hovedavtalen mellom YS og N.A.F. skulle ikke reforhandles før utgangen av 1989, men mellom de samme partene og mellom N.A.F. og enkelte av YS medlemsforbund besto det en rekke avtaler som utløp på ulike tidspunkter fra 31. mars til 30. juni 1988 (s. 61). Det var følgelig på det rene at loven kunne få betydning for partenes tariffoppgjør. Dette ble avgjørende for at Arbeidsretten kom til at aksjonen var i strid med fredsplikten. Retten bemerket at spørsmålet om det burde vedtas en ny inntekstreguleringslov prinsipielt sett var et politisk spørsmål, og videre at det var klart at aksjonen hadde et politisk formål (s. 69). Aksjonen var likevel i strid med fredsplikten fordi realiseringen av formålet kunne få betydning for utfallet av de forestående tariffoppgjørene. Arbeidsretten uttalte at «en realisering av det som var YS' siktemål med streiken, måtte kunne få innvirkning på premissene for de aktuelle tariffrevisjoner i det hele og derved også kunne tenkes å ha betydning for hvilke konkrete resultater YS ville kunne oppnå ved sine revisjoner» (s. 69). Det fremgår forutsetningsvis av denne uttalelsen at det hadde betydning at tariffoppgjørene var «aktuelle», herunder nært forestående. Retten må her ha siktet til oppgjørene som skulle skje innen de neste fire månedene.

70 Det fremgikk uttrykkelig av at oppslag fra Norsk Faglærerlag til deres medlemmer (s. 115). 


\subsection{ARD 1989 s. 134}

ARD 1989 s. 134 er i denne sammenheng et særtilfelle. Her ble grunnvilkåret ikke anvendt uttrykkelig, men etter min mening er det god grunn til å anse dommen for å bygge på analogibetraktninger fra grunnvilkåret. Situasjonen var imidlertid ganske annerledes enn den som foreligger der det er fattet vedtak om tvungen lønnsnemnd. I ARD 1989 s. 134 ble aksjonen gjennomført på et tidspunkt hvor partene befant seg i en tariffperiode. Det forelå derfor kun fredsplikt for det som var regulert i avtalen, jf kapittel 7 avsnitt 7.1. Situasjonen var også noe ulik den som forelå i ARD 1988 s. 61. Der var det på det rene at det skulle føres tarifforhandlinger mellom partene innen de fire neste måneder. I ARD 1989 s. 134 ble aksjonen gjennomført 9. juni 1989, mens overenskomsten mellom partene ikke skulle revideres før året etter (s. 137 og 141 forutsetningsvis). Den tidsmessige tilknytningen til et tariffoppgjør var derfor en del fjernere enn i ARD 1988 s. 61. Imidlertid hadde arbeidstakersiden ytret ønske om det skulle føres forhandlinger mellom partene før overenskomsten skulle revideres (s. 138).

Bakgrunn for saken var kort sagt at bankforeningene hadde vedtatt å legge ned Bankakademiet. $^{71}$ Arbeidsretten kom til aksjonens formål dels var å protestere mot bankforeningenes saksbehandling, dels å oppfordre til omgjøring av avviklingsvedtaket (s. 146). Det siste av disse formålene ble avgjørende for at aksjonen var i strid med fredsplikten. Arbeidsretten viste til at «realiseringen av formålet hadde tilknytning til, og kunne ha betydning for, de forhandlinger forbundet selv ønsket ført» (s. 149). Dette var forhandlinger som var underlagt fredsplikt i tariffperioden, jf kapittel 7 avsnitt 7.2. Det er først og fremst henvisningen til at «realiseringen av formålet ... kunne ha betydning for ... forhandlinger» som innebærer at det kan være naturlig å snakke om analogi fra grunnvilkåret, og særlig fra ARD 1988 s. 61. Premissene i ARD 1989 s. 134 forholder seg ikke til ARD 1988 s. 61 direkte ved begrunnelsen av at det ene formålet var tariffstridig. Likevel er begrunnelsene for at formålene i de to dommene var i strid med fredsplikten, svært like. I begge dommene ble det avgjørende at realiseringen av formålet kunne få

\footnotetext{
71 Saken er omtalt en flere ganger tidligere, se kapittel 6 avsnitt 6.2 og punkt 6.33 og kapittel 7 avsnitt 7.2.
} 
betydning for en tariffrevisjon. En sentral forskjell mellom de to sakene var imidlertid arten av den beslutningen aksjonen hadde til formål å demonstrere mot. I ARD 1988 s. 61 var det et direkte siktemål med beslutningen (lovvedaket) å påvirke tariffoppgjøret. Dette var ikke tilfelle for beslutningen i ARD 1989 s. 134. Beslutningen i ARD 1988 s. 61 hadde følgelig langt flere likhetstrekk med en beslutning om tvungen lønnsnemnd enn beslutningen om nedleggelse av Bankakademiet.

\subsection{Sammenfatning}

Rettmessighetsvurderingen der grunnvilkåret kommer til anvendelse, skiller seg på flere måter fra rettmessighetsvurderingen i andre tilfeller. Først og fremst er det en ulikhet når det gjelder spørsmålet om hvilke formål som er omfattet av fredsplikt. Utenfor grunnvilkårets område er det kun rettstvister, herunder utøvelse av styringsrett, og interessetvister som det vil være i strid med fredsplikten å demonstrere mot. Når det gjelder grunnvilkåret, kan det også komme i strid med fredsplikten å demonstrere mot inngrep som kan få betydning for utfallet av et aktuelt tariffoppgjør.

En annen forskjell er at det der grunnvilkåret har anvendelse, ikke har vært gitt uttrykk for at det må være et hovedformål å demonstrere mot forhold som er omfattet av fredsplikt, og at dette er et nødvendig vilkår for at aksjonen er i strid med fredspliktens saklige side. Derimot er det lagt vekt på hvorvidt det har foreligget et formål som er tariffstridig, som et moment blant andre i en helhetsvurdering. I denne vurderingen vil også den tidsmessige tilknytningen mellom aksjonen og et tariffoppgjør ha betydning. Dersom aksjonen gjennomføres på et tidspunkt hvor det pågår et tariffoppgjør mellom partene, vil den tidsmessige tilknytningen være klar. Dette vil være tilfelle der det er fattet vedtak om tvungen lønnsnemnd. Rettspraksis viser imidlertid at grunnvilkåret også kan få anvendelse for aksjoner som gjennomføres både før et tariffoppgjør kommer i gang og etter at et tariffoppgjør er avsluttet. I ARD 1988 s. 61 fikk grunnvilkåret anvendelse for et tariffoppgjør som skulle finne sted innenfor en periode på fire måneder etter aksjonen ble gjennomført. ARD 1970 s. 72 viser at grunnvilkåret kan få anvendelse for et tariffoppgjør 
som er avsluttet. Her ble grunnvilkåret gitt anvendelse for Riksmeglingsmannens «kobling» av et tariffoppgjør mellom partene etter arbeidstvistloven $1927 \S 35$ nr. $7 .^{72}$ Der var det imidlertid også et viktig moment at det var et formål å presse motparten til å gå gjenoppta forhandlinger som var brutt. ${ }^{73}$

72 Lov 5. mai $1927 \mathrm{nr} .1$ om arbeidstvister [opphevet] (arbeidstvistloven 1927)

73 Se nærmere Nerdrum 1989 s. 189. 


\section{Del III: Andre forhold som kan ha betydning for en politisk aksjons rettmessighet}

\section{Introduksjon}

Til nå har problemstillingen vært hvordan man trekker grensen mellom politiske aksjoner og opptreden med et for nært forhold til fredspliktens saklige side, herunder hva som skal til for at en aksjon er i strid med fredsplikten på grunn av dens formål. Dette spørsmålet har vært diskutert i Arbeidsrettens praksis i lang tid. Problemstillingen i denne delen av oppgaven er derimot om en aksjon kan være i strid med fredsplikten selv om den etter sitt formål er forenlig med fredsplikten. Dette er en problemstilling av mer «moderne» art. Det

første spørsmålet er om en aksjon kan bli urettmessig på grunn av mangler ved forhåndsvarslingen av aksjonen. Den andre er i hvilken grad aksjonens negative konsekvenser for tariffmotparten kan få betydning for rettmessighetsvurderingen. Dette omfatter også spørsmålet om det kan oppstilles et krav om at politiske aksjoner har kort varighet. 


\section{Varsel}

\subsection{ARD 1984 s. 85}

Det har lenge vært usikkert om det kan oppstilles et selvstendig rettmessighetsvilkår om at politiske aksjoner varsles på forhånd. Så vidt jeg kan se, finnes det kun to dommer som belyser dette spørsmålet: ARD 1984 s. 85 og ARD 2001 s. 209.

ARD 1984 s. 85 gjaldt en aksjon som ble iverksatt av Rederiansatte Oljearbeideres Fellesforbund (ROF). Bakgrunnen for saken var at det i april 1984 var sluttet en tariffavtale mellom ROF og Arbeidsgiverforeningen for Skip og Offshorefartøyer (ASO). Tariffavtalen bygget på at ASO ikke skulle inngå tariffavtaler med andre organisasjoner som ga vesentlig bedre $\varnothing$ konomisk resultat for stillingsgrupper som også var omfattet av tariffavtalen med ROF (s. 86). Etter at avtalen mellom ROF og ASO ble inngått, inngikk ASO en tariffavtale med De Samarbeidende Organisasjoner (DSO). ROF hevdet at denne avtalen ga vesentlige bedre vilkår enn det som fulgte av deres tariffavtale. ROF gikk derfor til sak mot ASO og krevde prinsipalt at tariffavtalen med DSO ble lagt til grunn for forholdet mellom ROF og ASO. Den 12. juni 1984 ble det avsagt dom i Arbeidsretten som frifant ASO. Dagen etter meldte ROF gjennom Dagsrevyen at de overveiet full streik som følge av at Arbeidsretten avviste ROFs krav om nye tarifforhandlinger. Aksjonen ble deretter varslet gjennom en rekke ulike medier 14. juli, og som følge av dette tok ASO kontakt med ROF for å få avklart flere forhold rundt den varslede aksjonen (s. 87). ROF besvarte ikke henvendelsen, men vedtok likevel å gå til en «politisk streik» fra 15. juli kl 18. Det ble gjennomført aksjoner i samsvar med varselet.

Arbeidsretten kom til at ROFs aksjoner var tariffstridige og ulovlige. En viktig del av begrunnelsen for dette var ROFs fremgangsmåte i forbindelse med forhåndsvarslingen av aksjonen. Arbeidsretten la her vekt på at ROF hadde gitt opplysninger om aksjonen til mediene både før det var fattet endelig vedtak om aksjonen og før de hadde varslet ASO. 
Det ble også sett hen til at ROF ikke hadde besvart ASOs henvendelse av 14. juli hvor ASO etterspurte ytterligere opplysninger om den aksjonen de var blitt gjort oppmerksom på gjennom mediene. Om dette uttalte Arbeidsretten: «Det hører med til korrekt fremgangsmåte at den annen part gis formelt varsel om den politiske streik man vil gå til, grunnen til aksjonen og dens varighet» (s. 91). Et formildende moment overfor ROF var imidlertid at ASO likevel hadde fătt vite om den planlagte aksjonen gjennom mediene. Videre vurderte retten hvilke opplysninger ASO rent faktisk hadde fått om aksjonen. Her la Arbeidsretten vekt på at ROF hadde gjort kjent hvilket omfang streiken skulle få i bredde, men også på at varslingen var mangelfull fordi det ikke ble gitt opplysninger om varigheten av aksjonen (s. 91-92). Det var ikke «korrekt» fremgangsmåte, og retten bemerket at «motparten skal underrettes om varighet på forhånd» (s. 92).

Det forelå følgelig to mangler ved det varselet som var gitt. For det første ved måten det var varslet på; ROF hadde ikke varslet direkte til tariffmotparten og hadde heller ikke besvart henvendelser fra denne. For det andre hadde ROF ikke varslet om aksjonens varighet. Disse to momentene var en så sentral del av rettens begrunnelse, at det kan spørres om de utgjorde den eneste begrunnelsen for rettens resultat. Dette blir spørsmålet i det følgende.

Før retten vurderte forhåndsvarslingen av aksjonen, ble det bemerket at aksjonen hadde en varighet på tolv timer, og at dette var «uvanlig og treng[te] saklig begrunnelse for ikke å være i strid med fredsplikten» (s. 91). Arbeidsretten så også hen til at det ville være lite rimelig om det skulle være adgang til å gå til politisk streik mot en arbeidsrettsdom som var tapt. Etter omtalen av disse to forholdene, uttalte retten likevel at «andre grunner [førte] til at streiken [måtte] anses for ulovlig og tariffstridig» (s. 91). Det følger av denne bemerkningen at momentene om varighet og aksjonens sammenheng med den tapte arbeidsrettsdommen, ikke var en avgjørende del av begrunnelsen for rettens resultat. Etter å ha vurdert varslingen av aksjonen, og derfor også etter den nevnte uttalelsen om at andre grunner ble avgjørende, trakk retten imidlertid frem også andre momenter som talte for urettmessighet. Det ble sett hen til at ROFs uttalelser viste at det var et formål å markere 
misnøye med en påstått diskriminerende behandling ved et avsluttet tariffoppgjør, og deretter uttalt at det var «klart» at dette var i strid med fredsplikten (s. 92). Retten trakk også frem at et «vesentlig motiv» var å uttrykke misnøye med den tariffrettslige situasjon og å øve press på ASO for å få til endringer i tariffavtalen. Dette siste er utvilsomt et formål som er i strid med fredsplikten, jf kapittel 7 avsnitt 7.2. Ettersom retten uttrykkelig trakk frem disse to momentene, er det også grunn til å gå ut $\mathrm{i}$ fra at disse ble vektlagt av retten. At flere momenter enn manglene ved forhåndsvarslingen hadde betydning, har også støtte $\mathrm{i}$ at retten viste til at de «[u $] \mathrm{t}$ fra en samlet vurdering» kom til at aksjonene var tariffstridige og ulovlige (s. 92; min kursivering). På denne bakgrunn har jeg kommet til at manglene ved forhåndsvarslingen av aksjonen, ikke utgjorde en selvstendig grunn for rettens resultat. Det ble også lagt vekt på at ulike formål med aksjonen var i strid med fredsplikten.

Det neste spørsmålet blir om enkelte uttalelser i ARD 1984 s. 85 gir grunnlag for å oppstille et vilkår om forhåndsvarsling, på tross av at manglene ved forhåndsvarslingen ikke alene ble avgjørende for rettens resultat. På den ene side kan Arbeidsrettens uttalelse om at det «skal» underrettes om varighet på forhånd (s. 92), tale for at retten var av den oppfatning at det gjaldt et vilkår om forhåndsvarsling. Det samme gjelder bemerkningen om at det hørte med til «korrekt fremgangsmåte» at motparten ble varslet på forhånd (s. 91). Arbeidsretten gikk imidlertid ikke nærmere inn på hva som ville bli konsekvensene av at disse prosedyrene ikke var fulgt, og det er like nærliggende å gå ut fra at retten kun mente å gi uttrykk for hvilken fremgangsmåte den aksjonerende part burde følge. Etter dette er jeg kommet til at premissene i ARD 1984 s. 85 er altfor usikre til å kunne gi grunnlag for et selvstendig vilkår for forhåndsvarsling.

\subsection{ARD 2001 s. 209}

Det neste spørsmålet blir om ARD 2001 s. 209 kan gi grunnlag for å kjenne en aksjon urettmessig alene på grunn av mangler ved forhåndsvarslingen av aksjonen. I denne saken bygget arbeidsgiversiden sin påstand om at aksjonen var urettmessig kun på at det forelå mangler ved forhåndsvarselet av aksjonen. Det var ikke anført at aksjonens formål var i 
strid med fredsplikten (s. 212). Her var det iverksatt en aksjon av EL \& IT Forbundet rettet mot en stortingsproposisjon om endringer i lovgivningen om arbeidsformidling og arbeidsleie. Den 24. november 1999 varslet EL \& IT Forbundet tariffmotparten, NAVO, om at det var planlagt å gjennomføre en aksjon mot stortingsproposisjonen (s. 209-210). Etter dette varselet var det usikkert om og i tilfelle når en aksjon ville bli gjennomført fordi aksjonen var avhengig av Stortingets behandling av den aktuelle saken. Den 9. desember ble imidlertid El \& IT Forbundet gjort kjent med innholdet av den kommende innstillingen fra Stortingets kommunalkomité, og 10. desember sendte EL \& IT Forbundet ut et skriv til sine medlemmer med oppfordringer til en politisk streik den 16. desember (s. 210). Den 14. desember sendte NAVO et brev per telefaks til forbundet og etterspurte ytterligere opplysninger om den tidligere varslede aksjonen. Dette brevet ble besvart av EL \& IT Forbundet per e-post dagen etter. Her ble det opplyst om at aksjonen ville bli gjennomført 16. desember fra kl 12-14. EL \& IT Forbundets representant forsøkte også å komme i kontakt med mottakeren for e-posten per telefon. Dette lyktes ikke, men det ble oppnådd kontakt med en ved samme kontor som bekreftet at mottakeren skulle bli kontaktet umiddelbart (s. 218).

Arbeidsretten kom til at de to varslene av 24. november og 14. desember samlet sett innebar at aksjonen var tilstrekkelig varslet på forhånd. Det ble dermed ikke nødvendig å gå inn på det generelle spørsmålet om det kunne oppstilles et selvstendig rettmessighetsvilkår om at politiske aksjoner ble varslet på forhånd. Arbeidsretten uttalte her at det ikke ble «aktuelt å gå inn på spørsmålet om utilstrekkelig varsling av en politisk demonstrasjonsstreik i seg selv kan føre til at iverksettelse av den til være tariffstridig eller ulovlig» (s. 220). Innledningsvis i dommen gikk retten likevel langt i å argumentere for at det kunne oppstilles et slikt vilkår (s. 217). Det ble blant annet vist til uttalelsen fra ARD 1984 s. 85 om at «[d]et hører med til korrekt fremgangsmåte at den annen part gis formelt varsel om den politiske streik man vil gå til, grunnen til aksjonen og dens varighet». Videre ble det bemerket at partene var enige om at det kunne oppstilles et krav om forhåndsvarsling, og at juridisk teori, praksis i arbeidslivet og hensynet til bedriftene tilsa at det burde oppstilles et slikt krav. På tross av disse bemerkningene gir likevel ikke 
ARD 2001 s. 209 grunnlag for å oppstille et selvstendig vilkår om forhåndsvarsling, jf rettens bemerkning om at det ikke ble aktuelt å ta stilling til spørsmålet (s. 220). Dommen gir imidlertid veiledning for spørsmålet om hva som uansett må anses som tilstrekkelig varsel. Dette vil være temaet i det følgende.

Ved den nærmere vurderingen av om det var tilstrekkelig varslet, uttalte retten at dette måtte bero på «en konkret vurdering av omstendighetene i den enkelte sak» (s. 218). Ved denne vurderingen la Arbeidsretten vekt på en rekke ulike momenter knyttet til de to varslene som var gitt; hvem det var varslet til, hvilken form det var varslet ved, varslenes innhold og til slutt om det var varslet i tilstrekkelig god tid før iverksettelsen av aksjonen. Jeg vil behandle momentene i denne rekkefølgen.

Et moment retten la vekt på var hvem det var varslet til. Det var på det rene at tariffmotparten, NAVO, var varslet om aksjonen, både ved varselet av 24. november og av 14. desember. Retten var imidlertid av den oppfatning at også de enkelte arbeidsgiverne skulle vært varslet. Dette fremgår av uttalelsen om at en e-post til organisasjonsleddene «ikke kunne anses som en tilstrekkelig varslingsforanstaltning overfor bedriftene» (s. 220). Ved vurderingen av om bedriftene kunne anses for å være varslet, så Arbeidsretten hen til en e-post sendt fra EL \& IT Forbundet til distrikter og landsomfattende klubber. EL \& IT Forbundet hadde anført at denne e-posten måtte innebære at det var varslet overfor bedriftene (s. 216). Det førte ikke frem for Arbeidsretten. Det ble begrunnet med at eposten ikke var sendt til de lokale klubbene ved de enkelte bedriftene, og med at e-posten ikke inneholdt noen oppfordring til å underrette arbeidsgiverne om tidspunktet for aksjonen. Det ser følgelig ut til at Arbeidsretten bygget på at et varsel til den lokale klubben kunne vært tilstrekkelig. En forutsetning for dette synes imidlertid å være at et slikt varsel inneholder en oppfordring om å varsle videre til den enkelte bedrift.

Arbeidsretten vurderte også om formen det var varslet med var tilfredsstillende. Som utgangspunkt for denne drøftelsen, bemerket retten at den ikke fant grunnlag for å stille opp «bestemte krav til forhåndsvarselets form»(s. 218). Det var imidlertid enighet mellom 
partene om at varselet av 24. november ved brev, hadde en tilfredsstillende form. Dette sluttet også Arbeidsretten seg til. Men fordi det var usikkert om det første varselet tilfredsstilte innholdsmessige krav, vurderte retten også om det andre varselet var gitt på adekvat måte. Det andre varselet ble, som nevnt foran, gitt ved e-post og fulgt opp med telefonisk kontakt med adressatens kontor. I samtalen ble det opplyst om at varsel var sendt per e-post, og kontoret bekreftet at rette vedkommende ville bli kontaktet umiddelbart. Ved vurderingen av denne varslingsprosedyren tok Arbeidsretten utgangspunkt i hvilke hensyn det andre varselet skulle ivareta, hvilket var at utfyllende opplysninger skulle komme frem til rette vedkommende så fort som mulig. Retten så deretter hen til at andre forsendelsesmåter neppe ville vært mer tjenlige. Det andre varselet hadde derfor en «fullt forsvarlig form» (s. 218). At det var essensielt å få varslet raskt, ble følgelig tillagt avgjørende vekt ved vurderingen av det andre varselets form, selv om det berodde på arbeidstakersiden selv at det ikke var varslet tidligere. EL \& IT Forbundet fikk nemlig utfyllende opplysninger om aksjonen hele fire dager før de varslet tariffmotparten. ${ }^{74} \mathrm{Et}$ forhold som trolig virket inn på vurderingen av om det andre varselet hadde en tilfredsstillende form, var at det første varselet opplyste om viktige sider av aksjonen og utvilsomt hadde en tilfredsstillende form. Det har støtte i at retten gjentatte ganger viste til at spørsmålet om det var tilstrekkelig varslet måtte vurderes konkret, herunder i at det ble uttalt at det andre varselet «under de omstendigheter som forelå» hadde en forsvarlig form (s. 218).

Når det gjaldt varslenes innhold, bemerket retten at NAVO hadde erkjent at det etter det andre varselet var varslet tilstrekkelig med hensyn til innhold (s. 218). Det var da varslet om aksjonens bakgrunn, aksjonsformen, hvilket omfang aksjonen ville ha $\mathrm{i}$ bredde, tidspunktet for gjennomføring av aksjonen og aksjonens varighet. ${ }^{75}$ Retten tok ikke stilling til om det første varselet var tilstrekkelig innholdsmessig. Ut fra dette varselet var det

74 Den 10. desember sendte EL \& IT Forbundet ut varsel til distrikter og landsomfattende klubber om at det skulle gjennomføres en politisk aksjon 16. desember (s. 210). NAVO ble ikke varslet om det endelige tidspunktet før 14. februar (s. 211).

75 Se gjengivelsen av de to varslene (s. 210 og 211). 
usikkert om en aksjon ville bli gjennomført og i tilfelle når dette ville skje. Derimot tok Arbeidsretten stilling til spørsmålet om det andre varselet var gitt i tide. Da dette spørsmålet ble besvart bekreftende, ble det ikke nødvendig å ta stilling til spørsmålet om det første varselet var tilstrekkelig innholdsmessig. Heller ikke her fant retten grunn til å oppstille bestemte krav. Arbeidsretten bemerket at «[s]pørsmålet om en politisk aksjon er varslet i tilstrekkelig god tid på forhånd, må vurderes i lys av de konkrete omstendigheter rundt aksjonen og de formål varselet skal tjene» (s. 218). Tidspunktene for de to varslene $\mathrm{i}$ ARD 2001 s. 209 gir derfor svært begrenset veiledning for andre saker. Det første varselet ble fremsatt drøye tre uker før iverksettelsen av aksjonen, og det andre varselet to døgn før iverksettelsen.

Et sentralt hensyn i vurderingen av om det var varslet $i$ tide, var om bedriftene hadde tilstrekkelig tid til å områ seg før aksjonen (s. 219). Det ble her tatt utgangspunkt i det tidspunktet det lyktes NAVO å komme i kontakt med sine medlemmer. Arbeidsretten la til grunn at det skjedde i løpet av ettermiddagen og kvelden den 14. desember. Det var da halvannet døgn til aksjonen skulle iverksettes. Ved drøftelsen av om dette var tilstrekkelig tid for bedriftene til å forberede seg på aksjonen, la Arbeidsretten vekt på hvilket skadepotensiale aksjonen måtte antas å ha. Retten foretok ingen konkret vurdering av hvor lang tid bedriftene trengte til å områ seg, men fant det avgjørende at det ikke var «godtgjort» at aksjonen hadde et så stort eller uvanlig skadepotensiale, at den burde vært varslet «i spesielt godt tid på forhånd» (s. 218-219). Rettens bruk av begrepet «godtgjort» viser at bevisbyrden lå på den som hevdet at aksjonen hadde et spesielt stort skadepotensiale, her arbeidsgiversiden.

Et neste og svært viktig moment i rettens vurdering av om det var varslet i tide, var partenes opptreden i prosessen forut for aksjonen og i forbindelse med varslene. Dette kan stikkordsmessig betegnes som lojalitet. I disfavør av arbeidsgiversiden ble det lagt vekt på to momenter: at NAVO ikke hadde varslet videre til sine medlemmer etter det første varselet (s. 219) og at de hadde forholdt seg passive overfor tariffmotparten ved å unnlate å etterspørre ytterligere opplysninger om den planlagte aksjonen (s. 219). Som begrunnelse 
for vektleggingen av det første forholdet kan det anføres at dersom arbeidsgiversiden ikke i størst mulig grad selv søker å ivareta hensynet til å begrense aksjonens skadevirkninger, er det heller ikke rimelig å kreve at motparten gjør det. Til støtte for det andre kan det nevnes at det ville virke urimelig dersom den part som rammes av aksjonen ikke orienterer den aksjonerende part om en mulig urettmessighetsgrunn ved aksjonen når denne fortsatt er mulig å reparere, men heller venter til aksjonen gjennomføres for så å påberope seg forholdet som en urettmessighetsgrunn.

Arbeidstakersidens opptreden talte etter rettens syn dels for at det var varslet i tide, og dels mot at det var varslet i tide. Samlet sett synes imidlertid Arbeidsretten å ha bygget på at det var liten grunn til å klandre EL \& IT Forbundet. Det ble lagt stor vekt på at EL \& IT Forbundet ved det første varselet «lojalt hadde søkt å gi forhåndsvarsel i så god tid som mulig» (s. 219). Kort tid etter det var truffet vedtak om politisk streik, ble motparten varslet med de opplysninger som da forelå. Arbeidsretten viste også til at EL \& IT Forbundet hadde god grunn til å forutsette av NAVO umiddelbart varslet videre til sine medlemsbedrifter etter det første varselet (s. 219). Som argument mot at det var varslet i tide, ble det vist til at EL \& IT Forbundet hadde en klar oppfordring til å gi utfyllende opplysninger med en gang de faktisk fikk kunnskap om forholdene. Likevel ble utfyllende varsel først gitt fire dager etter dette.

Rettens mindretall, de to dommerne fra arbeidsgiversiden, var uenige i flertallets vurdering av om at det var varslet i tide. Mindretallet mente at hensynet til å forebygge skadevirkninger ikke ble tilstrekkelig ivaretatt i det korte tidsintervallet mellom 14. og 16. desember. Som begrunnelse viste de til at politiske aksjoner «i utgangspunktet ikke skal ramme arbeidsgiver». Dersom de ved uttalelsen mente å si at en politisk aksjon som utgangspunkt ikke skal gripe inn arbeidsgivers rett til å disponere over arbeidstakerne, er den etter mitt syn lite treffende. Det typiske for politiske aksjoner er jo nettopp at de er rettmessige, selv om de rammer arbeidsgiver. Som det fremgår av det som er sagt om mindretallets vurdering her, var de imidlertid ikke uenige med flertallet $\mathrm{i}$ at bedriftenes behov for å områ seg, er et viktig moment ved vurderingen av i hvor god tid en politisk aksjon bør varsles. Men i motsetning til flertallet mente mindretallet at det ikke kunne tillegges vekt at NAVO ikke hadde etterspurt ytterligere opplysninger fra arbeidstakersiden tidligere. Mindretallet 
la derimot til grunn at det ikke kunne hvile noen plikt på motparten til å innhente supplerende opplysninger. Endelig var det et viktig moment at EL \& IT Forbundet ikke hadde gitt utfyllende opplysninger til NAVO med en gang de fikk slike opplysninger. I tillegg viste de til at det andre varselet kom som et resultat av at NAVO hadde etterspurt ytterligere opplysninger. Dette talte også mot at det var varslet i tide.

\subsection{Sammenfatning}

Fremstillingen til nå har vist at det fortsatt er usikkert om det kan oppstilles et selvstendig rettmessighetsvilkår om at politiske aksjoner skal varsles på forhånd. Selv om enkelte uttalelser i både ARD 1984 s. 85 og ARD 2001 s. 209 kan trekke i retning av at det kan oppstilles et slikt vilkår, kan ingen av dommen anses for å ha tatt definitiv stilling til spørsmålet.

Arbeidsrettens vurderinger av varslene i de to dommene bygget først og fremst på to hensyn: hensynet til at arbeidsgiver skal gis mulighet til å begrense skadevirkningene av aksjonen og hensynet til lojalitet mellom partene. At det første av disse hensynene var viktig, fremgår direkte av ARD 2001 s. 209. At dette hensynet også lå til grunn for rettens vurdering i ARD 1984 s. 85, har støtte i at retten trakk frem at arbeidsgiver faktisk hadde fått vite om aksjonen, selv om arbeidstakersiden ikke hadde varslet dem direkte (s. 91). Dette kan forstås som en henvisning til at det ikke var avgjørende at det ikke var varslet direkte når arbeidsgiver likevel visste om aksjonen og derfor hadde mulighet til å forberede seg på den.

At lojalitet var et viktig hensyn i rettens vurdering i ARD 2001 s. 209 fremgår direkte av fremstillingen foran. Dette hensynet må imidlertid også antas å ha vært viktig i ARD 1984 s. 85 hvor det ble lagt vekt på at arbeidstakersiden ikke hadde besvart arbeidsgiversidens forespørsler om ytterligere informasjon om aksjonen. 
I ARD 2001 s. 209 hadde arbeidsgiversiden anført et ytterligere hensyn til begrunnelse for en varslingsplikt: at den part som ble rammet av aksjonen skulle gis tilstrekkelig tid til å vurdere aksjonens berettigelse og til å bringe en eventuell tvist inn for Arbeidsretten. Hensynet ble ikke uttrykkelig trukket frem av retten, og det er derfor usikkert hvorvidt arbeidsgivers interesse i å vurdere aksjonens berettigelse før aksjonen iverksettes, kan ha betydning for vurderingen av om tilstrekkelig forhåndsvarsel er gitt.

\subsection{Særskilt regulering av varsling}

Jeg går nå over til å drøfte om enkelte særskilte reguleringer av varsling i tariffavtaler, kan gi grunnlag for noe annet enn det som følger av rettspraksis. Jeg har kun funnet to eksempler på at forhåndsvarsling av politiske aksjoner er uttrykkelig regulert i tariffavtaler. ${ }^{76}$ Bestemmelser om dette finnes i Hovedavtalen LO - NHO del A § 3-14 og Hovedavtale HSH - LO § 6-3. Bestemmelsene er identiske, og det fremgår av dem at politiske aksjoner «skal» forhåndsvarsles. Umiddelbart synes bestemmelsene å oppstille et absolutt krav om forhåndsvarsling av politiske aksjoner. Av bestemmelsenes tredje ledd fremgår det imidlertid at bestemmelsene ikke tar sikte på å endre den rettstilstand som er skapt gjennom Arbeidsrettens praksis. Denne bemerkningen isolert sett, taler for at bestemmelsen ikke har noe selvstendig innhold. Etter ordlyden foreligger det følgelig en innholdsmessig motstrid i bestemmelsene. Det er ikke sikkert at partene mente å oppstille et vilkår om forhåndsvarsling til tross for at dette ikke fulgte av Arbeidsrettens praksis.

Bestemmelsene kom inn i hovedavtalene ved revisjonene høsten 2001, altså kort tid etter at dommen i ARD 2001 s. 209 ble avsagt. At denne dommen utgjorde en del av bakgrunnen for bestemmelsene, fremgår av LOs kommentarer til Hovedavtalen LO - NHO

76 Som presisert i del I kapittel 2, har jeg ikke foretatt noen fullstendig undersøkelse av i hvilken utstrekning enkelte tariffavtaler har uttrykkelig bestemmelser som regulerer adgangen til politiske aksjoner. 
2002-2005. ${ }^{77}$ Jeg finner imidlertid ikke grunnlag for at dette faktum gir noen nærmere veiledning for hvordan de to bestemmelsene skal forstås. Heller ikke LOs øvrige kommentarer gir noen klar løsning på spørsmålet. Det samme gjelder NHO sine kommentarer. ${ }^{78}$ På den ene side presiserer begge partene at det med bestemmelsen ikke var meningen å endre rettstilstanden slik den var skapt av Arbeidsretten.

I LOs kommentarer heter det: «Bestemmelsen tar ikke sikte på å endre rettstilstanden vedrørende politiske demonstrasjonsaksjoners slik den er fastlagt gjennom Arbeidsrettens praksis.» I NHOs kommentarer heter det: «Det har ikke vært partenes mening å endre den bestående rettstilstanden på dette området.»

På den annen side er det andre bemerkninger som kan trekke i retning av at partene tok sikte på å oppstille et vilkår om forhåndsvarsling uavhengig av hva som fulgte av Arbeidsrettens praksis. I LOs kommentarer er det etter presiseringen av forholdet til Arbeidsrettens praksis, bemerket at bestemmelsen «mest er av opplysende karakter» (min kursivering). Bruken av begrepet «mest» kan indikere at LO mener at bestemmelsen har en funksjon ut over den rent opplysende. I NHOs kommentarer slås det fast at reglene om forhåndsvarsling «tidligere [har] vært uklare», og at det nå ble tatt inn en «presisering» $\mathrm{i}$ avtalen. Dette kan tilsi at NHO også var av den oppfatning at bestemmelsen skulle gi et selvstendig grunnlag for et vilkår om forhåndsvarsling uavhengig av hva som fulgte av Arbeidsrettens praksis.

Det er etter dette uklart om bestemmelsene gir et selvstendig grunnlag for å oppstille et vilkår om forhåndsvarsling, eller om de er av rent orienterende karakter. Videre i dette avsnittet vil jeg kort gå inn på hvilke krav som stilles til forhåndsvarslingen i bestemmelsene. Spørsmålet er; dersom bestemmelsene gir grunnlag for å oppstille et krav om forhåndsvarsling, hvilke krav stiller bestemmelsene til forhåndsvarselet.

\footnotetext{
77 Hovedavtalen LO - NHO 2002-2005 med tilleggsavtaler og kommentarer (LOs kommentarer) s. 115 116.

78 Hovedavtalen 2002 - 2005 LO - NHO. Med tilleggsavtaler og NHOs kommentarer s. 16.
} 
For det første følger det av bestemmelsene at varslingsplikten hviler på den som oppfordrer til aksjonen, og at det er tariffmotparten som skal varsles. Det fremgår imidlertid også av bestemmelsene at den som oppfordrer til aksjonen skal «sørge for» varsling til aktuelle tillitsvalgte og bedrifter. Men plikten til å varsle tillitsvalgte og bedrifter synes å være mindre streng enn plikten til å varsle tariffmotparten, jf at motparten «skal» varsles, og at man må «sørge for» varsling til bedriftene. Her er det mulig at bestemmelsen bygger på vurderingen i ARD 2001 s. 209. Der ble det ikke avgjørende at det ikke var varslet direkte til bedriftene. I tillegg bygget Arbeidsretten på at et varsel til de lokale klubbene ved de enkelte bedriftene, kunne vært tilstrekkelig til at EL \& IT Forbundet hadde oppfylt sin plikt til å varsle bedriftene.

Bestemmelsene $\mathrm{i}$ de to hovedavtalene sier også noe om hva et varsel «bør» inneholde opplysninger om: tidspunktet for aksjonen, aksjonens bakgrunn og den forventede varighet. Bestemmelsene sier ingenting om hva som blir konsekvensene av at det ikke er gitt slike opplysninger. Et alternativ er at dette vil kunne vektlegges i en helhetsvurdering av om det er gitt tilstrekkelig varsel. Et annet alternativ er at det overhodet ikke vil ha rettslig betydning om varselet ikke opplyser om vedkommende forhold. Et tredje alternativ er at Arbeidsrettens praksis her blir avgjørende. Også på dette punkt er det usikkert hvordan bestemmelsene skal forstås.

Når det gjelder spørsmålet om når det må varsles, fremgår det av bestemmelsene at dette skal skje «så tidlig som omstendighetene tillater». Her er det vanskelig å si noe generelt, ut over at dette må bero på en konkret vurdering av når den som oppfordrer til aksjonen ble sikker nok på at det kom til å bli gjennomført en politisk aksjon. På bakgrunn av ARD 2001 s. 209, som bestemmelsene bygger på, er det også grunn til å hevde at det ikke er nødvendig at vedkommende sitter med alle de opplysningene som det skal varsles om, for at varslingsplikten skal inntre. 


\section{Varighet og virkninger}

\subsection{Innledning}

Problemstillingen i dette kapittelet er i hvilken grad aksjonens varighet og negative konsekvenser for tariffmotparten kan få betydning for vurderingen av politiske aksjoners rettmessighet. I ARD 2001 s. 88 ble en aksjon kjent urettmessig alene fordi det ikke forelå «en rimelig grad av forholdsmessighet mellom aksjonens varslede varighet og de antatte konsekvenser av den» (s. 106). ${ }^{79}$ Det er følgelig på det rene at en aksjon kan bli urettmessig uten at dens formål er i strid med fredsplikten. Hovedspørsmålet i dette kapittelet blir hva som er innholdet av den forholdsmessighetsnormen som ble lagt til grunn i ARD 2001 s. 88. Før jeg går nærmere inn på dette, vil jeg knyttet noen bemerkninger til eldre rettspraksis.

\subsection{Eldre rettspraksis}

I følge eldre rettspraksis kunne varigheten få betydning på ulike måter når man vurderte en aksjons rettmessighet. For det første kunne varigheten få betydning ved å være et bevismoment for hva aksjonens reelle formål er. Dette har jeg gjort rede for i kapittel 8 avsnitt 8.2 foran. Varigheten ble imidlertid også brukt som et selvstendig moment i rettmessighetsvurderingen. Med «selvstendig moment» sikter jeg til situasjoner hvor varigheten i seg selv utgjør et argument for urettmessighet, i motsetning til situasjoner hvor den fungerer som et bevismoment for aksjonsformålet. Den første dommen hvor varigheten fikk betydning som et selvstendig moment er ARD 1979 s. $116 .{ }^{80}$ I eldre rettspraksis fantes det imidlertid ikke noe eksempel på at en aksjon var blitt funnet urettmessig alene på grunn

\footnotetext{
79 Slike konsekvenser som behandles her, må skilles fra slike virkninger som jeg redegjorde for i kapittel 8 , avsnitt 8.2. Jeg viser til det som ble sagt der angående skillet mellom de to ulike formene for virkninger.

$80 \quad$ Nerdrum 1989 s. 197.
} 
av dens varighet. Varigheten inngikk alltid som et moment i en helhetsvurdering hvor også aksjonens formål var viktig. ${ }^{81}$

Når det gjelder spørsmålet om hvor lang varighet som kunne brukes som argument for urettmessighet, kom Arbeidsretten med følgende generelle uttalelse i ARD 1984 s. 85: «en politisk streik [må] for å være lovlig og ikke tariffstridig ... være kort. De fleste slike streiker er også korte, mange under en time, langt de fleste under 3 timer, og meget få varer en arbeidsdag. 12 timers varighet er uvanlig og trenger saklig begrunnelse for ikke å være $\mathrm{i}$ strid med fredsplikten» (s. 90-91). Sentrale deler av uttalelsen ble gjentatt i ARD 1985 s. 40 (s. 48). Formuleringen tilsier at det må særlige grunner til dersom en aksjon med en varighet på tolv timer skal godtas. I eldre rettspraksis fantes det imidlertid ingen dommer hvor formuleringen var blitt lagt til grunn for rettens resultat, heller ikke i de to nevnte dommene. $^{82}$

Det var utvilsomt grunnlag i eldre rettspraksis for å legge vekt på en aksjons varighet ved vurderingen av aksjonens berettigelse. Grunnlaget for å legge vekt på aksjonens negative konsekvenser for arbeidsgiver for $\varnothing$ vrig, var imidlertid langt svakere. Jeg har kun funnet én dom hvor aksjonens negative konsekvenser for arbeidsgiver uttrykkelig ble trukket frem: ARD 1979 s. 116. Retten uttalte at det ville føre til «helt uholdbare resultater i arbeidslivet - til skade for både bedriftene, arbeidstakerne og samfunnet - om mer eller mindre langvarig eller stadig gjentatt arbeidsstans eller arbeidsnedleggelse skulle bli akseptert ...» (s. 124). Momentet om aksjonens virkninger for arbeidsgiver ligger i hensivningen til at det ville føre til «uholdbare resultater» blant annet for bedriftene. Mulige negative konsekvenser blant annet for arbeidsgiver, ble anvendt som en begrunnelse for et mulig krav til kort varighet. Også i eldre rettspraksis var det følgelig grunnlag for å se aksjonens varighet og virkninger i sammenheng. At aksjonen i ARD 1979 s. 116 ble kjent urettmessig, ble imidlertid også begrunnet $\mathrm{i}$ andre omstendigheter, herunder med at det var enighet mellom partene i hovedtariffavtalen at det var gjennomført en urettmessig aksjon,

\footnotetext{
$81 \quad$ Nerdrum 1989 s. 195.

$82 \quad$ Nerdrum 1989 s. 198.
} 
og med at aksjonen hadde sammenheng med lønns- og arbeidsvilkår (s. 122-123). Momentet om aksjonens varighet og virkninger utgjorde følgelig bare et av flere momenter $i$ en helhetsvurdering av aksjonens rettmessighet.

\subsection{Nyere rettspraksis}

\subsection{Rettspraksis frem til ARD 2001 s. 88}

Jeg har ikke funnet noe eksempel på at varigheten eller aksjonens negative konsekvenser ble brukt som et selvstendig moment som talte for urettmessighet i perioden mellom ARD 1985 s. 40 og ARD 2001 s. 88. Imidlertid er det avsagt tre dommer hvor retten uttrykkelig bemerket at det ikke var nødvendig å gå inn på varigheten: ARD 1989 s. 47, ARD 1990 s. 180 og ARD 1993 s. 147. Felles for disse tre dommene er at retten kom til at aksjonene var i strid med fredsplikten etter sitt formål. Det at Arbeidsretten unnlot å trekke inn varigheten ved vurderingen av aksjonens forhold til fredsplikten, kan tyde på at varighetens stilling var i ferd med å endre seg i forhold til eldre rettspraksis; fra å være et moment ved en helhetsvurdering til å bli et selvstendig rettmessighetsvilkår. ${ }^{83}$ Dette argumentet styrkes av at aksjonene i ARD 1989 s. 47 og ARD 1993 s. 147 varte lenger enn aksjonen i ARD 1982 s. 150 hvor varigheten ble trukket frem i en helhetsvurdering av aksjonens rettmessighet. Jeg kan heller ikke se at det var mer tvil angående aksjonenes forhold til fredspliktens saklige side i de tre nye dommene, enn det som var tilfelle i eldre rettspraksis hvor varigheten ble trukket inn. Etter min mening er det derfor god grunn til å anse de tre dommene som ledd i en gradvis utvikling i retning av å godta varigheten som et selvstendig rettmessighetsvilkår.

83 Jf kapittel 8 avsnitt 8.2 . 


\subsection{ARD 2001 s. 88}

Det er etter dette helt klart at Arbeidsretten skapte ny rett i ARD 2001 s. 88. Dette er den første dommen hvor en aksjon ble kjent urettmessig alene på grunn av dens varighet og negative konsekvenser for arbeidsgiver. Spørsmålet i dette avsnittet blir hvordan forholdsmessighetsnormen som ble lagt til grunn i ARD 2001 s. 88 skal forstås. Før jeg går inn på dette spørsmålet, vil jeg si litt om faktum i saken og rettens utgangspunkter for vurderingen som ledet frem til forholdsmessighetskravet.

Saken gjaldt en aksjon blant ansatte ved Statoils installasjoner varslet av Oljearbeidernes Fellessammenslutning (OFS). Aksjonen, som skulle gjennomføres ved en arbeidsnedleggelse, var varslet å ha en varighet på tolv timer (s. 94). Arbeidsnedleggelsen medførte at en rekke oljebrønner måtte stenges. Nedstengningen av den enkelte brønn kunne ta fra to til åtte timer, og oppkjøringen av enkelte brønner kunne i verste fall ta 24 timer (s. 105). Oppkjøringen vil først starte etter at aksjonen var avsluttet. Arbeidsgiversiden anførte at en helhetsvurdering av aksjonens formål, varighet og virkninger måtte føre til at den var urettmessig. Arbeidsretten kom imidlertid til at formålet med aksjonen var forenlig med fredsplikten. ${ }^{84}$ Spørsmålet som gjensto, var deretter om varigheten og virkningene førte til at aksjonen ikke var rettmessig.

Som utgangspunkt for denne vurderingen bemerket Arbeidsretten at det på grunnlag av rettspraksis siden ARD 1960 s. 1 var etablert et vilkår om at politiske aksjoner måtte ha kort varighet (s. 104). I likhet med det som fremgår av avsnitt 11.2 foran, erkjente retten at det ikke fantes noe eksempel på at en aksjon var funnet urettmessig alene på grunn av dens varighet. Arbeidsretten mente likevel at de «gjentatte understrekninger» av kravet om kort varighet i rettspraksis, ga grunnlag for å oppstille et slikt vilkår.

84 Jf kapittel 6 avsnitt 6.32 og kapittel 8 avsnitt 8.3. 
Ved vurderingen av hvor lang varighet en aksjon som ennå ikke er gjennomført vil ha, vil det være naturlig å ta utgangspunkt i den varslede varighet. Det ble også gjort i ARD 2001 s. 88 (s. 104). I tillegg la Arbeidsretten vekt på at perioden med helt eller delvis nedstengt produksjon ville være lengre enn den varslede varigheten. Perioden med delvis nedstengt produksjon kunne i verste fall komme opp i et og et halvt døgn. ${ }^{85}$

Etter å ha tatt stilling til aksjonens varighet, må det vurderes om det foreligger forholdsmessighet mellom varigheten og virkningene. I denne vurderingen var det to hovedhensyn som ble sentrale for retten: arbeidstakernes behov for å få demonstrert sitt syn og hvilke negative konsekvenser aksjonen ville ha for arbeidsgiver. Innledningsvis bemerket retten at kravet til kort varighet «ikke kan stilles så strengt at arbeidstakerne ikke gis tilstrekkelig tid til å gjennomføre den politiske demonstrasjonen etter sin hensikt og forutsetninger» (s. 104). Det følger av dette at hensynet til arbeidsgiver ikke kan veie så tungt, at adgangen til å gjennomføre en aksjon som er rettmessig etter sitt formål, må avskjæres helt. Ved drøftelsen av arbeidstakernes behov for den varslede varigheten, ble det for det første lagt vekt på at aksjonen hadde «vesentlig lengre varighet» enn tidligere demonstrasjonsaksjoner som var varslet og iverksatt av OFS på installasjoner i Nordsjøen (s. 104-105). Det er god grunn til anta at retten her sluttet seg til arbeidsgiversidens anførsler om at dette viste at OFS evnet å gjennomføre politiske aksjoner av kortere varighet enn den foreliggende (s. 98).

Det neste momentet i rettens vurdering av arbeidstakernes behov, var om varigheten hadde en saklig begrunnelse. Arbeidstakersiden hadde anført at varigheten var begrunnet med $\emptyset$ nsket om at alle de ansatte skulle gis mulighet til å delta i aksjonen. Ordningen med skiftarbeid måtte, etter YS og OFS sine anførsler, innebære at man godtok en noe lengre varighet enn ellers (s. 101). Det førte ikke frem for Arbeidsretten. For det første bemerket retten at flere ville hatt mulighet til å delta dersom aksjonen var lagt til tidspunktet for et

\footnotetext{
85 Arbeidsnedleggelsen ville vare i tolv timer. Først etter at arbeidsnedleggelsen var avsluttet, ville oppkjøringen av oljebrønnene starte. Oppkjøringen av enkelte av brønnene kunne i verste fall ta opp til 24 timer, jf foran.
} 
skiftbytte. For det andre viste retten til at ønsket om at alle skulle få delta, ikke kunne antas å ha vært den viktigste begrunnelsen for varigheten (s. 105).

Det ble på denne bakgrunn ikke aktuelt for Arbeidsretten å ta stilling til spørsmålet om det var en forutsetning for at OFS skulle få demonstrert sitt syn at alle de aktuelle medlemmene fikk mulighet til å delta i aksjonen ved å legge ned sitt arbeid. Svaret på dette spørsmålet vil bero på om det er vesentlig at de ansatte demonstrerer ved å legge ned sitt arbeid eller om det er tilstrekkelig at de deltar i en demonstrasjon. ${ }^{86}$ Ut fra betraktninger om det som vil være politiske aksjoners formål annet enn det tariffregulerte - skulle det ikke være nødvendig at arbeidstakerne la ned sitt arbeid. Videre er det på det rene at også annen opptreden enn arbeidsnedleggelse, kan regnes som en politisk aksjon. Dette taler mot at det er nødvendig at alle de ansatte får markert seg i arbeidstiden. Etter min mening taler derfor de beste grunner for at det ikke er vesentlig at arbeidet nedlegges, og at det ikke uten videre vil være en saklig begrunnelse for varigheten at så mange som mulig gis mulighet til å legge ned sitt arbeid.

Den viktigste begrunnelsen for aksjonens varighet var i følge Arbeidsretten ønsket om å skaffe aksjonen publisitet. Dette ble ikke ansett som en saklig begrunnelse. Retten uttalte her at den hadde «vansker med å se det saklige grunnlaget for at en slik varighet var en nødvendig forutsetning for å gi OFS medlemmer anledning til å markere sitt syn» (s. 105).

Etter å ha foretatt vurderingen av varighetens saklige begrunnelse, gikk retten over til spørsmålet om hvilke negative konsekvenser aksjonen hadde for arbeidsgiver. Her ble det lagt vekt på at aksjonen ville få konsekvenser ut over den fastsatte aksjonsperioden, på grunn av prosedyrene for nedstengning og oppstarting av oljebrønnene. Dette fikk også konsekvenser for det tap arbeidsgiver ble påført ved aksjonen. Ut fra Statoils prisprognoser ville det totale tapet bli på rundt 110-130 millioner kroner. ${ }^{87}$ Beløpene var bestridt av motparten, men retten nøyde seg med å bemerke at tallene i alle fall var «illustrerende» for

$86 \quad$ Nerdrum 1989 s. 199.

87 Arbeidsretten støttet seg her til Statoils prognoser. Disse tilsa at den tapte produksjonen ville utgjøre 1,1 millioner fat olje, som med datidens priser utgjorde en verdi på 240 millioner kroner. I følge prognosene ville imidlertid halvparten av disse verdiene kunne gjenvinnes over tid (s. 105). 
de tap man stod overfor. Retten uttalte deretter at «de økonomiske konsekvensene av en mer kortvarig streik ville blitt betydelig mindre» (s. 106).

Konklusjonen ble så at det ikke forelå «en rimelig grad av forholdsmessighet mellom aksjonens varslede varighet og de antatte konsekvenser av den»(s. 106). Aksjonen var derfor tariffstridig og ulovlig. De to sentrale momentene som begrunnet dette var at det ikke var en saklig begrunnelse som gjorde varigheten nфdvendig for at arbeidstakerne skulle få demonstrert sitt syn (s. 105), og at de фkonomiske konsekvensene av en mer kortvarig aksjon ville blitt betydelig mindre (s. 106).

\subsection{Sammenfatning}

Selv om de rettslige utgangspunktene som trekkes opp i ARD 2001 s. 88 er forholdsvis klare, kan de konkrete vurderingene by på tvil i senere saker. Dette gjelder for det første vurderingen av hvilket behov arbeidstakerne har for den varslede varigheten. Her gir ARD 2001 s. 88 liten veiledning. Retten tok ikke direkte stilling til dette spørsmålet, men viste til at aksjonen varte lenger enn tidligere og lignende iverksatte demonstrasjoner fra OFS side (s. 105), jf avsnittet foran. Ved spørsmålet om hva som vil være tilstrekkelig for at den aksjonerende part skal få demonstrert sitt syn, kan eldre praksis om hva som normalt har blitt ansett som tilstrekkelig tid, være av betydning. Jeg viser til den tidligere siterte uttalelsen fra ARD 1984 s. 85 om at mange demonstrasjonsaksjoner er på én time, de fleste varer under tre timer og om at tolv timers varighet er uvanlig og trenger saklig begrunnelse (s. 91). Denne uttalelsen ble også gjentatt i ARD 2001 s. 88 og Arbeidsretten presiserte at dommen fra 1984 var den dom hvor kravet til kort varighet hadde fått sitt mest presise uttrykk (s. 104).

Det er også mulig at det var uttalelsen fra ARD 1984 s. 85 om at tolv timers varighet trengte saklig begrunnelse, som lå til grunn for at retten fant det avgjørende at varigheten ikke hadde noen saklig begrunnelse, fremfor å foreta en vurdering av om varigheten var nødvendig for at den aksjonerende part skulle få demonstrert sitt syn. Premissene i 
ARD 2001 s. 88 gir imidlertid ikke direkte grunnlag for en slik forståelse, og det er usikkert om saklighetskriteriet, slik det ble lagt til grunn i ARD 2001 s. 88, kun gjelder i tilfeller hvor varigheten er spesielt lang, eller om det gjelder generelt.

Ved den konkrete vurderingen av om aksjonen hadde en saklig begrunnelse, bygget Arbeidsretten på at den viktigste begrunnelsen for varigheten, som var å skaffe aksjonen publisitet, ikke var saklig, jf punkt 11.32 foran. I utgangspunktet er det vanskelig å se hvorfor dette ikke var en saklig begrunnelse, særlig fordi det er nærliggende å anta at et $\emptyset n s k e$ om å skaffe aksjonen publisitet, har grunnlag i tanken om at mer publisitet trolig vil $\varnothing \mathrm{ke}$ aksjonens signaleffekt på det politiske formålet. En grunn til at publisitetshensynet ikke ble ansett som en saklig begrunnelse, kan være at retten bygget på at ønsket om å skaffe publisitet ikke var begrunnet med en hensikt om å styrke signaleffekten på det politiske formålet. En annen mulighet er at retten var av den oppfatning at publisitetshensynet ikke kunne være den viktigste begrunnelsen for varigheten. Arbeidsrettens premisser på dette punkt er imidlertid altfor usikre til å kunne si noe sikkert om hva som lå bak oppfatningen om at publisitetshensynet ikke var en saklig begrunnelse.

Da Arbeidsretten så hen til hvilke negative konsekvenser aksjonen ville ha for arbeidsgiver, ble det først og fremst lagt vekt på aksjonens $\phi$ konomiske konsekvenser for arbeidsgiver. Det ble derimot ikke uttrykkelig lagt vekt på at aksjonen rent faktisk innebar et inngrep i arbeidsgivers styringsrett ved at arbeidsgiver var forhindret fra å disponere over arbeidstakerne i den perioden aksjonen pågikk. Etter min mening ville det heller ikke være heldig om Arbeidsretten vektla et slikt faktisk inngrep ved vurderingen av aksjonens varighet. Jeg viser her til at det karakteristiske for politiske aksjoner nettopp er at de er rettmessige selv om de innebærer et inngrep i arbeidsgivers kompetanse til å disponere over sine arbeidstakere. Et hvert slikt inngrep kan derfor ikke utgjøre noe argument for å kjenne en aksjon urettmessig. ${ }^{88}$ Muligens kan dette stille seg annerledes dersom aksjonen har spesielt lang varighet, hvilket for så vidt var tilfelle i ARD 2001 s. 88.

88 Se tilsvarende Dahl 1973 og denne avhandlingens kapittel 8 avsnitt 8.2 om betydningen av aksjonens virkninger ved formålsvurderingen. 
ARD 2001 s. 88 berører ikke spørsmålet om aksjonens negative konsekvenser for andre enn tariffmotparten og deres medlemmer kan få betydning for bedømmelsen av en aksjons rettmessighet. Jeg har bare funnet én dom hvor hensynet til andre uttrykkelig er trukket frem; ARD 1979 s. 116. Her uttalte retten at «det vil føre til helt uholdbare forhold i arbeidslivet - til skade for bedriftene, arbeidstakerne og samfunnet - om mer eller mindre langvarig eller stadig gjentatt arbeidsstans eller arbeidsnedleggelse skulle bli akseptert som lovlig pressmiddel mot ansvarlige politiske myndigheter»(s. 124; min kursivering). Den siterte uttalelsen ble imidlertid ikke avgjørende for rettens resultat, jf avsnitt 11.2. En antydning om det samme finnes i ARD 1984 s. 85, hvor uttalelsene om aksjonens varighet ikke var konkret knyttet til den betydning varigheten ville ha for tariffmotparten (s. 124). Men heller ikke her fikk uttalelsen avgjørende betydning for rettens resultat, jf avsnitt 11.2. Det er etter dette et åpent spørsmål i hvilken grad aksjonens negative konsekvenser for andre enn tariffmotparten, vil kunne ha betydning for rettmessighetsvurderingen, selv om ARD 2001 s. 88 utvilsomt har bidratt til å styrke tanken om at andre momenter enn aksjonens formål, kan bli avgjørende. 


\section{Del IV: Avsluttende bemerkninger}

Fra og med 1989 har det kun vært avsagt 13 dommer hvor retten har tatt stilling til grensen mellom politiske aksjoner og fredsplikten. Rettskildematerialet er følgelig begrenset i omfang, men samtidig forholdsvis variert i bredde. Dette har den fordel at mange ulike spørsmål er tatt opp, men samtidig den ulempe at enkelte viktige spørsmål kun er behandlet én gang. Samlet sett gir rettskildebildet inntrykk av at vurderingen overfor den som hevder at en opptreden er rettmessig som en politisk demonstrasjon, er streng. Bare i én av de 13 dommene kom Arbeidsretten til at opptredenen var rettmessig som en politisk aksjon. ${ }^{89}$

Når det gjelder de to leddene i vurderingen av om en aksjon er i strid med fredspliktens saklige side, er det særlig vurderingen av hva aksjonens reelle formål er, som er streng, i kapittel 8 kalt «formålskravet». Det finnes ikke noe eksempel på at retten først har kommet til at det forhold saksøker hevdet at aksjonen hadde til formål å ramme, var omfattet av fredsplikt, og deretter konkludert med at det ikke var aksjonens formål å ramme vedkommende forhold. Det finnes imidlertid eksempler på at Arbeidsretten har kommet til at de forhold aksjonen etter saksøkers anførsler hadde til formål å ramme, ikke var omfattet av fredsplikt. Fra nyere rettspraksis er ARD 2001 s. 88 det eneste eksempelet. ${ }^{90}$ I eldre rettspraksis finnes det flere eksempler, blant annet ARD 1976 s. 23 og ARD 1979 s. 37.

En av problemstillingene som ble stilt innledningsvis i denne avhandlingen, var om nyere rettspraksis kunne sies å representere en utvikling eller endring av eldre rettspraksis. Dette spørsmålet må dels besvares bekreftende. For det første gir nyere rettspraksis bedre veiledning for vurderingen av hvilke beslutninger som er underlagt fredsplikt som følge av normen om arbeidsgivers styringsrett. Her har ARD 1995 s. 34 og ARD 2001 s. 88 bidratt

\footnotetext{
$89 \quad$ ARD 2001 s. 209.

90 Jeg finner ikke at ARD 2001 s. 209 er et treffende eksempel på det samme. Her var partene enige om at aksjonen ikke var i strid med fredspliktens saklige side. Det eneste spørsmålet retten måtte ta stilling til, var om aksjonen var urettmessig på grunn av mangler ved forhåndsvarslingen.
} 
til klargjøring av hvilke beslutninger i politiske organer som er underlagt fredsplikt. Videre er det lagt til grunn i ARD 2001 s. 243 at beslutninger fra andre enn arbeidsgiver kan anses som utøvelse av styringsrett.

Nyere rettspraksis innebærer også en videreutvikling av eldre rettspraksis når det gjelder spørsmålet om en aksjon kan bli urettmessig selv om den etter sin formål er forenlig fredsplikten. ARD 2001 s. 88 innebærer utvilsomt en nyskapning. Dommen er det første eksempelet på at en aksjon har blitt funnet urettmessig uten at noen del av dens formål var i strid med fredsplikten. Arbeidsretten begrunnet sitt resultat med at det ikke forelå en forholdsmessighet mellom aksjonens varighet og dens virkninger. ARD 2001 s. 209 er også viktig i denne sammenheng. Selv om det ikke ble aktuelt for Arbeidsretten å ta stillingen til om det kunne oppstilles et vilkår om forhåndsvarsling, gikk retten langt i å argumentere for at det gjaldt et slikt vilkår. Etter min mening vil det ikke være overraskende om Arbeidsretten i fremtiden skulle kjenne en aksjon urettmessig alene på grunn av dens varighet.

Det forhold at nyere rettspraksis viser at en aksjon kan bli urettmessig selv om dens formål er legitimt, gir også grunnlag for en annen overordnet betraktning: Nyere rettspraksis skiller i større grad enn eldre praksis, mellom vurderingen av en aksjons forhold til fredspliktens saklige side og vurderingen av andre forhold som kan fă betydning for rettmessigheten. Tidligere var det vanlig at forhåndsvarselet og aksjonens varighet og virkninger inngikk som momenter i en helhetsvurdering hvor aksjonens formål også var viktig, jf kapittel 10 avsnitt 10.1 og kapittel 11 avsnitt 11.2. Dette har jeg ikke funnet noe eksempel på i nyere rettspraksis. 


\section{Litteraturliste}

Litteratur

Andersen 1967

Bjerke 2012

Dahl 1973

Evju 1982a

Evju 1982b

Evju 1984

Evju 1985

Evju 1990

Evju 2003

Hasselbach 1990
Kristen Andersen. Fra arbeidslivets rett. Oslo: J.G. Tanum, 1967.

Jorun Bjerke. «Resignasjonsplikt i tariffretten», Arbeidsrett og arbeidsliv, bind 7, 2012, s. 1-102.

Karl Nandrup Dahl. «Fiskerigrensetvisten ved Island», Jussens Venner, nr. 8, 1973, s. 337-338.

Stein Evju. Forelesninger i arbeidsrett V 84, avsnitt 23 (manuskript, upublisert), 1982.

Stein Evju. Organisasjonsfrihet, tariffavtaler og streik. Oslo: Universitetsforlaget, 1982.

Stein Evju. «Tariffavtalens eftervirkning», Tidsskrift for Rettsvitenskap, nr. 97, 1984, s. 254-292.

Stein Evju. «Politiske demonstrasjonsstreiker», Lov og rett, nr. 8, 1985, s. 435-446.

Stein Evju. I: Arbetsrätten i Norden. Tore Sigeman, Arnmundur Backman, Stein Evju, Ole Hasselbach og Antti Suviranta. Stockholm: Nordisk Ministerråd, Nord 1990: 42, 1990, s. 225-316.

Stein Evju. «Arbeidsrett og styringsrett - et perspektiv», Arbeidsrett og arbeidsliv, bind 1, 2003, s. 3-32.

Ole Hasselbach. I: Arbetsrätten i Norden. Tore Sigeman, Arnmundur Backman, Stein Evju, Ole Hasselbach og Antti Suviranta. Stockholm: Nordisk Ministerråd, Nord 1990: 42, 1990, s. 5-82. 
Høgberg 2006

Alf Petter Høgberg. Kontraktstolkning. Oslo: Universitetsforlaget, 2006.

Knoph 1921

Ragnar Knoph. Hensiktens betydning for grensen mellom rett og urett. Kristiania Olaf Norlis Forlag, 1921.

Nerdrum 1989 Per Kaare Nerdrum. «Demonstrasjonsaksjoner». I: Aktuell arbeidsrett. Stein Evju (red.), Jan Fouger, Marius Nygaard Haug og Per Kaare Nerdrum. Oslo: Universitetsforlaget, 1989, s. 141-224.

Thorkildsen 1990 Tarjei Thorkildsen. «Annen arbeidskamp : en undersøkelse av fredspliktens rekkevidde ved annen arbeidskamp enn streik og lockout», Institutt for offentlig retts skriftserie, nr. 2, 1990, s. 1-87.

\section{Lovforarbeider}

Prop.134 L (2010-2011) Lov om arbeidstvister (arbeidstvistloven) og lov om lønnsnemnd i arbeidstvister (lønnsnemndloven) m.m.

NOU 2001: 14

Vårens vakreste eventyr...?

Ot.prp. nr. 33 (1965-66) Om endringer i lov om arbeidstvister.

Annet

Hovedavtalen LO - NHO 2002-2005 med tilleggsavtaler og kommentarer (LOs kommentarer)

Hovedavtalen LO - NHO 2002-2005. Med tilleggsavtaler og NHOs kommentarer.

Rettspraksis

Høyesterett

Rt. 1977 s. 902

Rt. 1993 s. 490 
Arbeidsretten

ARD 1920-21 s. 1

ARD 1982 s. 150

ARD 1922 s. 86

ARD 1984 s. 85

ARD 1923 s. 78

ARD 1985 s. 40

ARD 1928 s. 48

ARD 1985 s. 96

ARD 1935 s. 132

ARD 1987 s. 61

ARD 1937 s. 22

ARD 1988 s. 61

ARD 1953 s. 48

ARD 1989 s. 47

ARD 1958 s. 125

ARD 1989 s. 134

ARD 1960 s. 1

ARD 1989 s. 165

ARD 1966 s. 62

ARD 1990 s. 180

ARD 1970 s. 65

ARD 1991 s. 107

ARD 1970 s. 72

ARD 1993 s. 147

ARD 1971 s. 117

ARD 1994 s. 246

ARD 1972 s. 89

ARD 1994 s. 272

ARD 1975 s. 12

ARD 1995 s. 34

ARD 1975 s. 105

ARD 1997 s. 193

ARD 1976 s. 23

ARD 2001 s. 88

ARD 1976 s. 96

ARD 2001 s. 209

ARD 1979 s. 37

ARD 2001 s. 243

ARD 1979 s. 116

ARD 2001 s. 382

ARD 1981 s. 72 